\title{
WestVirginiaUniversity
}

THE RESEARCH REPOSITORY @ WVU

Graduate Theses, Dissertations, and Problem Reports

2013

\section{Evaluation of the bond strength of asphalt overlays}

Seth Knihtila

West Virginia University

Follow this and additional works at: https://researchrepository.wvu.edu/etd

\section{Recommended Citation}

Knihtila, Seth, "Evaluation of the bond strength of asphalt overlays" (2013). Graduate Theses,

Dissertations, and Problem Reports. 3393.

https://researchrepository.wvu.edu/etd/3393

This Thesis is protected by copyright and/or related rights. It has been brought to you by the The Research Repository @ WVU with permission from the rights-holder(s). You are free to use this Thesis in any way that is permitted by the copyright and related rights legislation that applies to your use. For other uses you must obtain permission from the rights-holder(s) directly, unless additional rights are indicated by a Creative Commons license in the record and/ or on the work itself. This Thesis has been accepted for inclusion in WVU Graduate Theses, Dissertations, and Problem Reports collection by an authorized administrator of The Research Repository @ WVU. For more information, please contact researchrepository@mail.wvu.edu. 


\title{
EVALUATION OF THE BOND STRENGTH OF ASPHALT OVERLAYS
}

\author{
Seth Knihtila
}

Thesis submitted to the

Benjamin M. Statler College of Engineering and Mineral Resources

at West Virginia University

in partial fulfillment of the requirements

for the degree of

Master of Science

In

Civil Engineering

Dr. John P. Zaniewski, PhD, Chair

Dr. Avinash Unnikrishnan, PhD

Dr. John Quaranta, PhD, P.E.

Department of Civil and Environmental Engineering

Morgantown, West Virginia

2013

Keywords: Bond Strength, Asphalt Overlays, Tack Material. 


\section{ABSTRACT \\ EVALUATION OF THE BOND STRENGTH OF ASPHALT OVERLAYS}

\section{Seth Knihtila}

The objective of this study was to develop a test method and testing device for measuring the bond strength between pavement layers. The research evaluated tack coat materials and mix designs for the West Virginia Department of Highways. The project included a laboratory and a field phase. For the laboratory work, $9.5 \mathrm{~mm}$ and $19 \mathrm{~mm}$ NMAS mix designs were evaluated. NTSS-1HM and SS-1h tack coats were evaluated. Two surface conditions were simulated; the interface was either cut HMA or milled HMA. Also, the effect of the AASHTO T-283 conditioning was evaluated as a subsidiary to the laboratory testing.

In the laboratory phase, initial testing concluded that compaction effort affected bond strength. Also it was found that the cut face and new HMA face of the sample exhibit different bond strengths. The effect of changing the NMAS from $9.5 \mathrm{~mm}$ to $19 \mathrm{~mm}$ did increase the bond strength, but not to a significant level. The cut faced samples exhibited higher bond strengths than the milled samples on average. The bond strengths of samples with or without tack coat were not statistically different. For milled and cut faced samples, the NTSS-1HM was superior to SS-1h. Emulsion set time from 0.25 to 2.0 hours was statistically significant for both milled and cut faced samples. The difference in bond strength between the AASHTO T283 conditioning and the non-conditioned samples was found to be statistically significant.

The laboratory study was augmented with field cores on an "as available” basis. In August 2012 the WV DOH sent 11 cores to NCAT for bond strength testing. Two tack coats were evaluated, Ultrafuse and CSS-1h. The Ultrafuse was applied at rates of $0.08,0.13,0.18$ $\mathrm{gal} / \mathrm{yd}^{2}$ and the CSS-1h was unspecified. The Ultrafuse was superior to CSS-1h. The Ultrafuse applied at $0.08 \mathrm{gal} / \mathrm{yd}^{2}$ exhibited the highest average bond strengths. Six cores were extracted from I-64 in Dunbar West Virginia. Three cores tested at $77^{\circ} \mathrm{F}$ exhibited bond average bond strengths of $136 \mathrm{psi}$, two cores tested at $71^{\circ} \mathrm{F}$ exhibited bond strengths of $196 \mathrm{psi}$, and one core tested at $19^{\circ} \mathrm{F}$ exhibited a bond strength of greater than 350 psi. 


\section{ACKNOWLEDGEMENTS}

I would like to express my appreciation and thanks to my Adviser, Dr. John Zaniewski for providing me with the opportunity to learn and perform research under him. I would also like to thank my Committee, Dr. Avinash Unnikrishnan and Dr. John Quaranta for their assistance along the way.

I would like to thank my fellow graduate students, Logan, Hadi, Brian, Masoud, Steve, and Kyle for their assistance in the office and the lab. I would like to thank John Crane from the WVDOH and Chad Miller from J.F. Allen for supplying the materials for my research. I also thank Don Williams and Mike Pumphrey of the WVDOH Research Division for the support of this research.

Lastly I would like to thank my parents Bob and Nancy, and my brother Ryan for their support throughout my studies. 


\section{ACRONYMS}

AASHTO - American Association of State Highway and Transportation Officials AC - Asphalt Concrete

ALDOT - Alabama Department of Transportation

ASTM - American Society for Testing and Materials

CRS-2 - Cationic Rapid Setting Emulsion

CSS-1h - Cationic Slow Setting Emulsion

DGAC - Dense Graded Asphalt Concrete

FDOT - Florida Department of Transportation

$\mathrm{G}_{\mathrm{mb}}-$ Bulk Specific Gravity

$\mathrm{G}_{\mathrm{mm}}-$ Theoretical Maximum Specific Gravity

HMA - Hot Mix Asphalt

LISST - Louisianna Interlayer Shear Strength Tester

LPDS - Layer Parallel Direct Shear

LTCQT - Louisiana Tack Coat Quality Tester

MTD - Mean Texture Depth

NCAT - National Center for Asphalt TEchnology

NMAS - Nominal Maximum Aggregate Size

NTSS-1hm - Non Tracking Tack Coat

PCC - Portland Cement Concrete

PG XX-YY - Performance Grade Binder

SGC - Superpave Gyratory Compactor

SMA - Stone Matrix Asphalt

SS-1h - Slow Setting Tack Coat

ULTRAFUSE - Highly Modified non-tracking tack coat 
UTEP - University of Texas El Paso

UTS - Universal Testing Machine

VDOT - Virginia Department of Transportation

VTM - Voids in the Total Mix

WV DOH - West Virginia Department of Highways 


\section{TABLE OF CONTENTS}

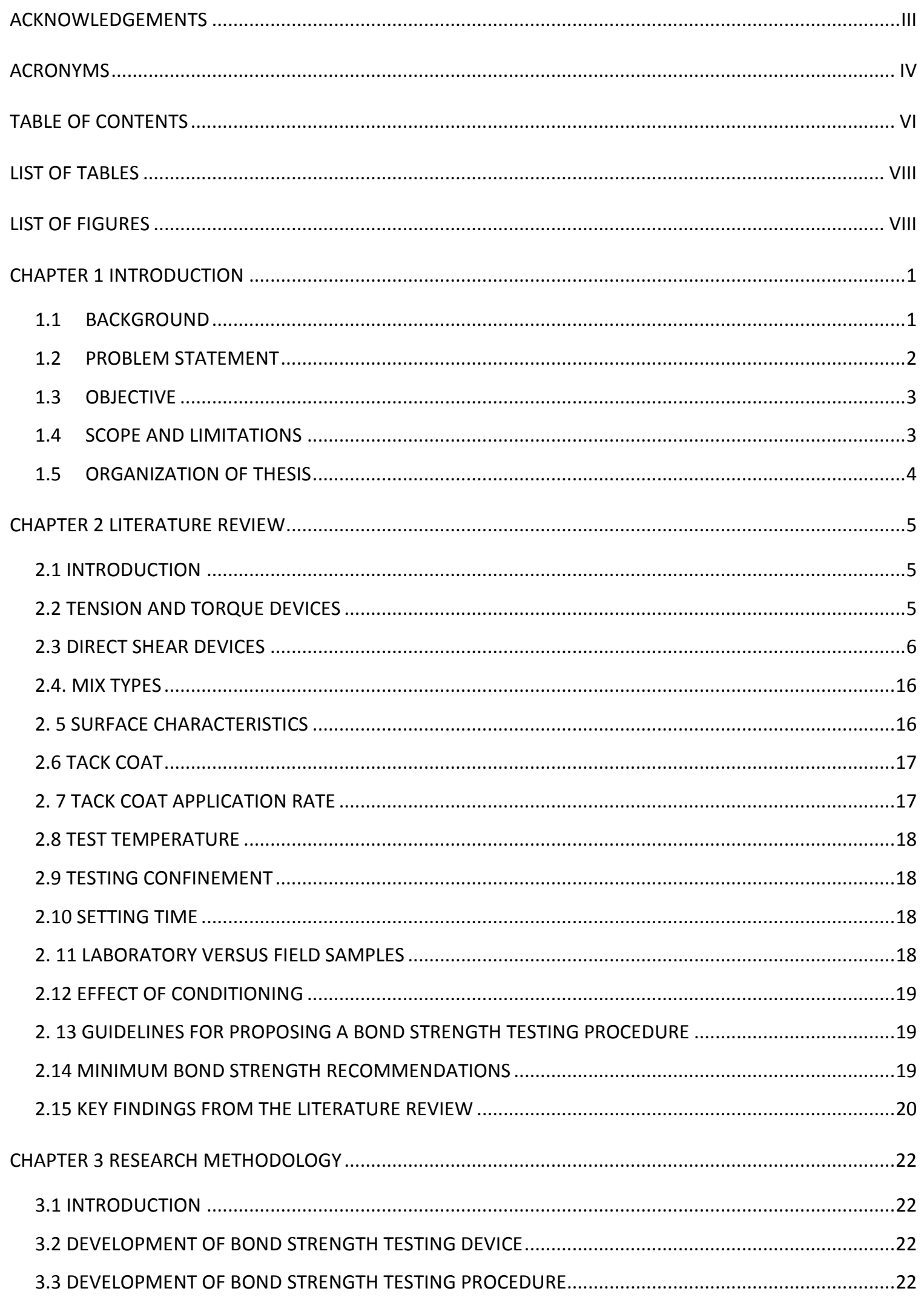


3.4 Development of a Laboratory Sample Preparation Procedure .......................................................23

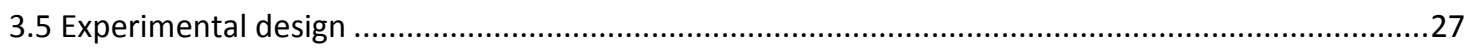

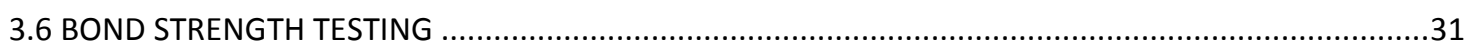

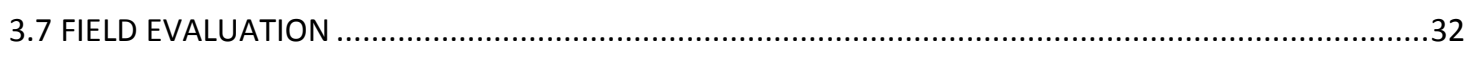

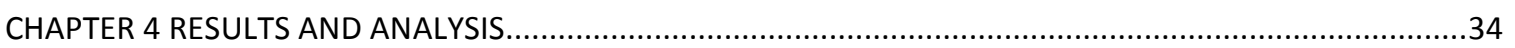

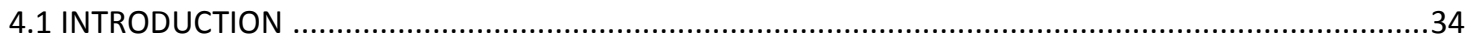

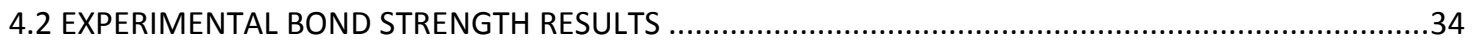

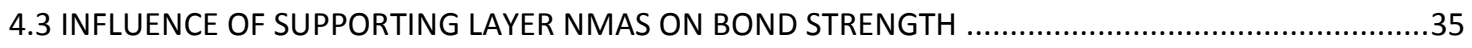

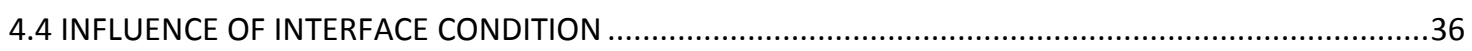

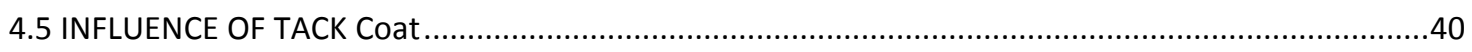

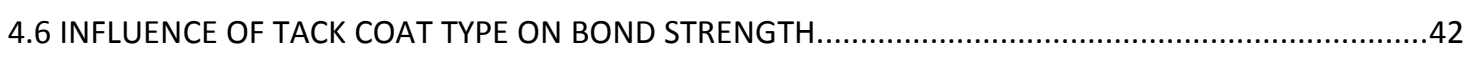

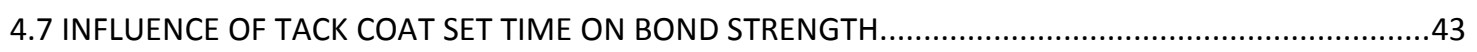

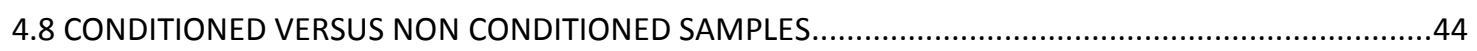

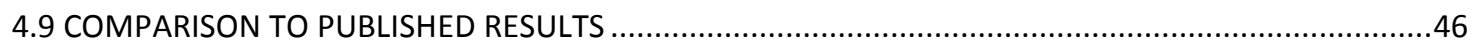

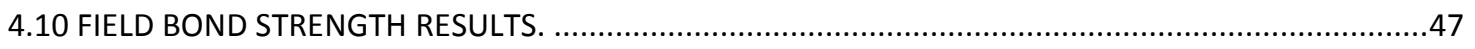

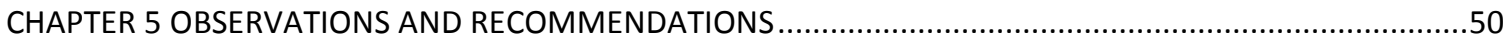

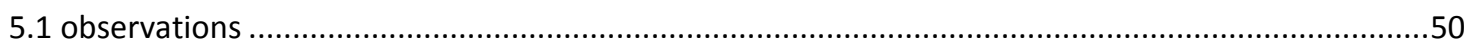

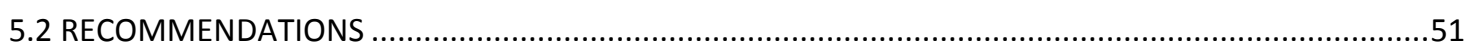

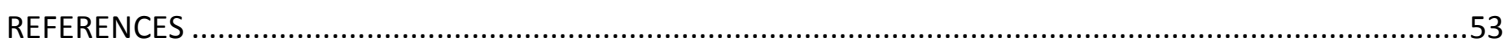

APPENDIX 1: BOND STRENGTH TESTING DEVICE TECHNICAL DRAWINGS ..............................................56

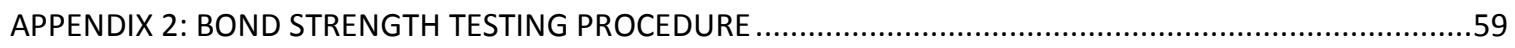

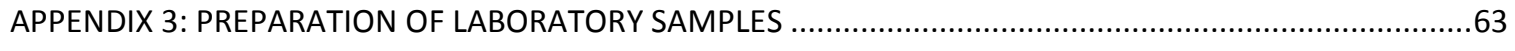

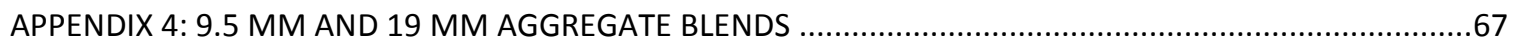

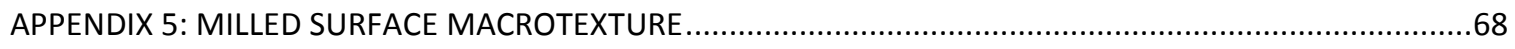

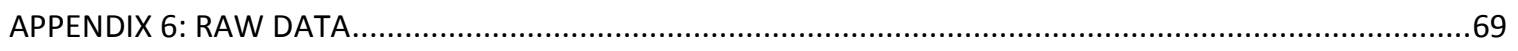

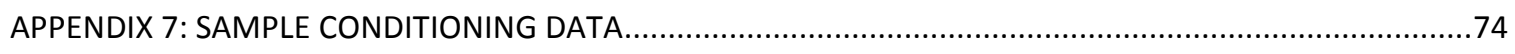

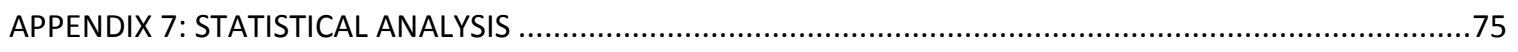




\section{LIST OF TABLES}

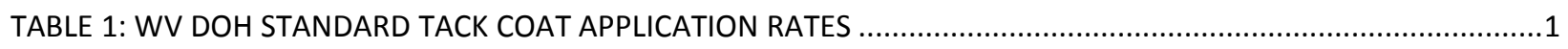

TABLE 2: SUMMARY OF DIRECT SHEAR BOND STRENGTH DEVICES ......................................................................

TABLE 3: MAXIMUM CONTACT STRESSES WITH DIFFERENT FRICTION COEFFICIENTS (WANG ET AL., 2010).............20

TABLE 4: EFFECT OF COMPACTION LEVEL ON VTM OF TOP LAYER AND BOND STRENGTH .....................................26

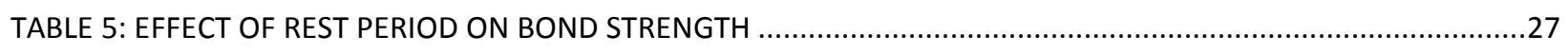

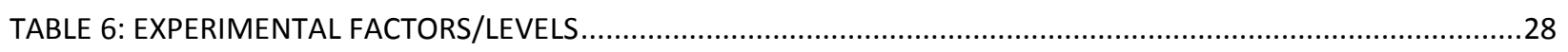

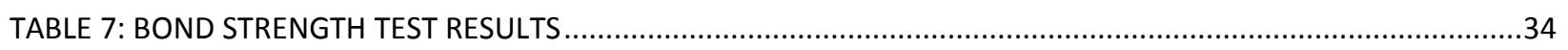

TABLE 8: STATISTICAL ANALYSIS OF TACKED VERSUS NON TACKED SAMPLES ….................................................42

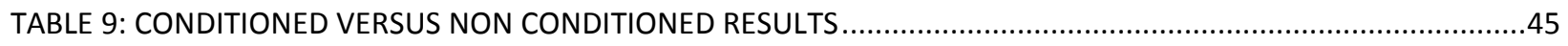

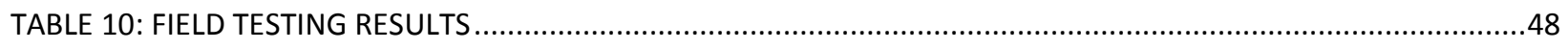

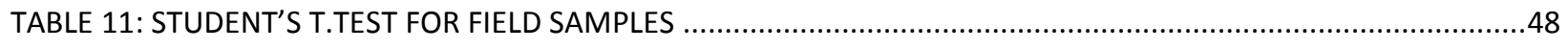

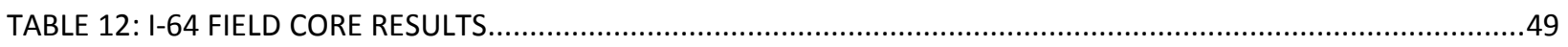

\section{LIST OF FIGURES}

FIGURE 1: SLIPPAGE FAILURE DUE TO INADEQUATE BOND (TRAN ET. AL., 2012) ...................................................

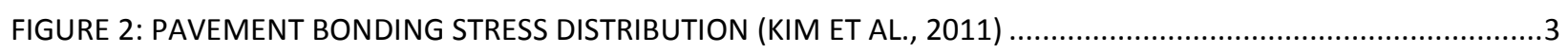

FIGURE 3: MARSHALL STABILOMETER LOADING FRAME (PINE INSTRUMENTS) ...................................................

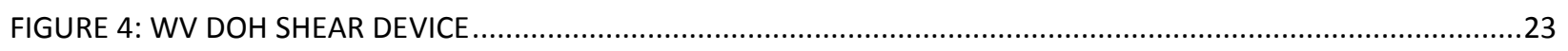

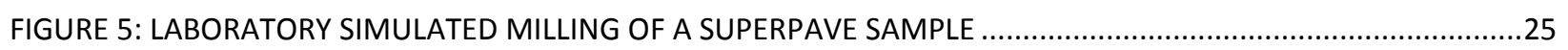

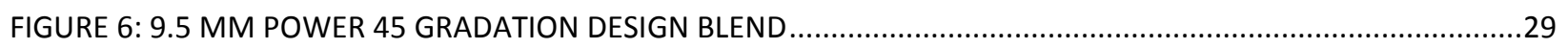

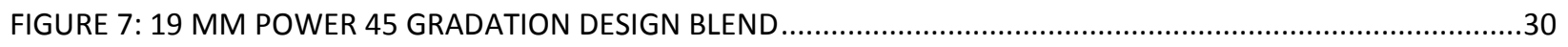

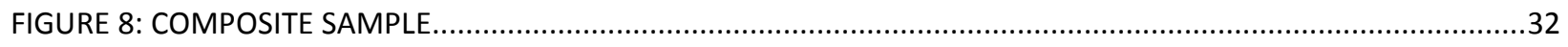

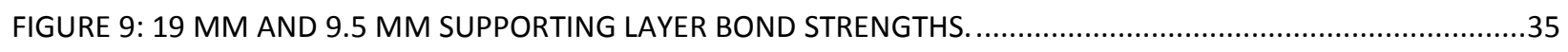

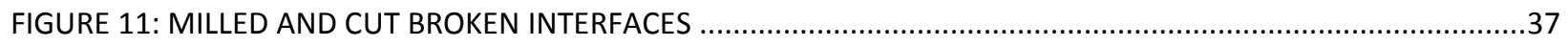

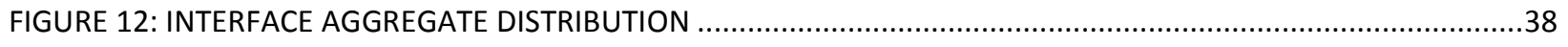

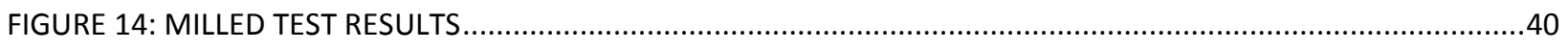

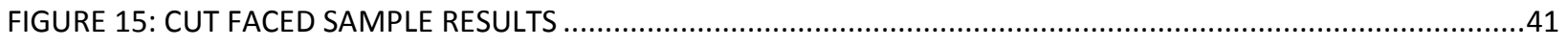

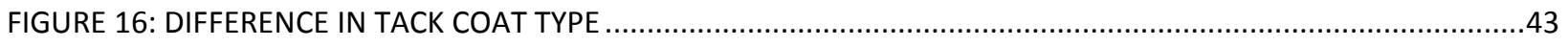

FIGURE 17: DIFFERENCE IN BOND STRENGTH BY VARYING SETTING TIME .........................................................4

FIGURE 18: INFLUENCE OF CONDITIONING ON BOND STRENGTH ..................................................................... 


\section{CHAPTER 1 INTRODUCTION}

\subsection{BACKGROUND}

As of 2005, there were approximately 4 million miles of roads of which 2.6 million miles were paved with asphalt or Portland Cement Concrete. Roughly 2.4 million miles were paved with Asphalt Concrete (Brown et al, 2009). Preservation of the existing highway infrastructure is the predominant activity of highway agencies throughout the US. Asphalt overlays of existing pavements are the dominant preservation strategy. Asphalt pavements are the load bearing structure while asphalt concrete is a precisely engineered mixture of three components: binder, aggregate, and air. The aggregate, typically naturally occurring or crushed, makes up approximately $95 \%$ of the mixture by mass, while the other $5 \%$ by mass is filled with binder. The air voids, typically $4 \%$ by volume, are important so that the mixture has room for thermal expansion.

As a result of the increased traffic demand from the road users, increasing rehabilitation costs and decreasing budgets, the design and construction of long lasting pavements is important (Raab and Partl, 2004). Rehabilitation includes the placement of a layer of asphalt concrete, as determined from the structural/traffic needs for the pavement, over an existing or milled asphalt pavement. Prior to placement of the overlay, a tack coat is applied to the pavement to help new asphalt concrete adhere to the existing surface. A tack coat is a light application of asphalt or asphalt emulsion used to bond one pavement layer to another (Santucci, 2009). The tack coat application rates, as specified by the West Virginia Department of Highways (WV DOH), are in Table 1.

Table 1: WV DOH Standard tack coat application rates

\begin{tabular}{|c|c|c|}
\hline \multirow{2}{*}{$\begin{array}{c}\text { Condition of } \\
\text { Existing Pavement }\end{array}$} & \multicolumn{2}{|c|}{$\begin{array}{c}\text { Application Rate } \\
\left(\mathrm{gal}^{\mathrm{y}} \mathrm{yd}^{2}\right)\end{array}$} \\
\cline { 2 - 3 } & Undiluted & Diluted $(1: 1)^{*}$ \\
\hline New HMA & $0.04-0.05$ & $0.08-0.10$ \\
\hline Oxidized HMA & $0.07-0.10$ & $0.13-0.20$ \\
\hline Milled Surface & $0.10-0.13$ & $0.20-0.27$ \\
\hline PC Concrete & $0.07-0.10$ & $0.13-0.20$ \\
\hline
\end{tabular}

*Assume emulsion is diluted with an equal volume of water 
Ensuring the bond strength between the overlay and existing surface is imperative to the life of the new structure. If the multi-layered asphalt pavement does not have ample bond strength to endure dynamic loads from traffic, typically present in areas of stopping, starting or turning, surface distresses may develop. These surface distresses are, but not limited to, debonding, delamination, slippage, or fatigue cracking. A slippage failure is shown in Figure 1.

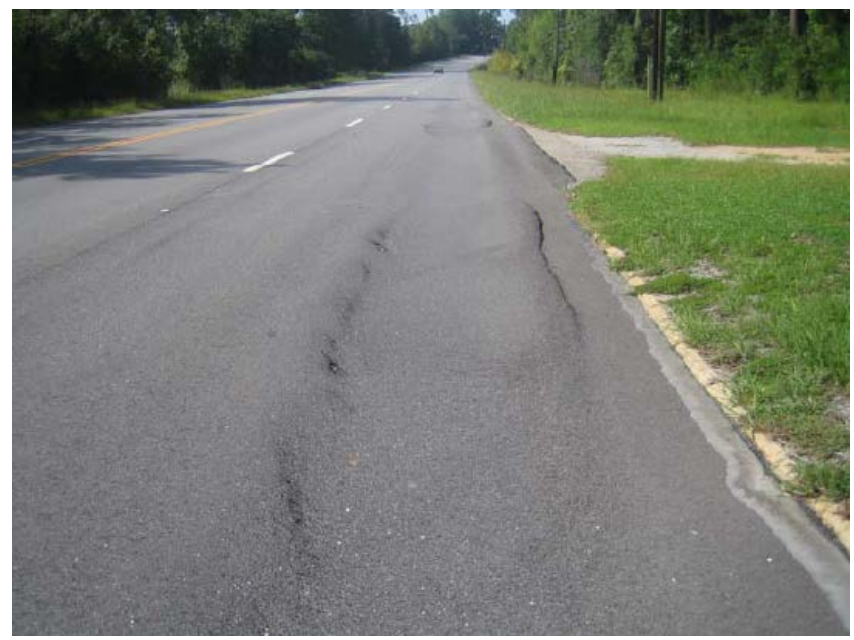

Figure 1: Slippage failure due to inadequate bond (Tran et. al., 2012)

These distresses are present in areas where the pavement does not exhibit a full bond condition between the two pavement layers. The stress distribution between the pavement layers is different between a full bond and a no bond condition, as exhibited in Figure 2. The fully bonded case has no stress at the interface, while the un-bonded case has a high concentration of stress at the interface. A partially bonded case, typical to in situ pavements, exhibits less stress concentration at the interface, but is still not in a fully bonded case.

\subsection{PROBLEM STATEMENT}

The bond strength at the interface of layers in asphalt pavements can be directly related to several premature failure mechanisms such as debonding, delamination, slippage cracks and reduced fatigue life. In order to increase the bond strength of multilayered asphalt pavements, modifications to the existing surface, i.e. milling and tack coats, are commonly implemented. The most commonly used tack coats are anionic or cationic slow setting emulsions, though hot asphalt binder and cutback asphalts have been used. Tack coats are applied at different rates, based on the existing surface type, as shown in Table 1. 
(a) Fully-bonded

(Low Temperature) (b) Partially-bonded

(for real pavements) (c) No-bonding

Aggregate Interlocking

(High Temperature)

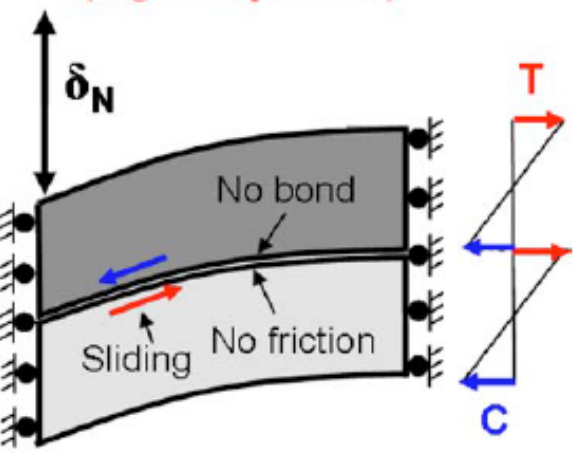

Figure 2: Pavement Bonding Stress Distribution (Kim et al., 2011)

\subsection{BJECTIVE}

The objective of this research study is to determine the bond strength at the interface of two asphalt pavement layers under different conditions. The effects of changing the Nominal Mix Aggregate Size (NMAS), surface condition, presence of tack coat, tack coat type, setting time, and conditioning methods were evaluated.

\subsection{SCOPE AND LIMITATIONS}

This research study was limited to the evaluation of typical pavement designs for West Virginia. The mix designs obtained from a West Virginia paving contractor are 9.5-mm and 19mm mix designs. The aggregate used in this study is limited to one quarry. Only NTSS-1hm and SS-1h tack coats were selected for this study. The NTSS-1hm stands for a non-tracking slow setting emulsion with standard grade viscosity, hard asphalt cement, and it's modified, while SS1h stands for a slow setting emulsion with standard grade viscosity and hard asphalt cement. The NTSS-1HM is a trackless tack coat. Evaluation of field cores was performed on an "as available” basis. 


\subsection{ORGANIZATION OF THESIS}

This thesis is divided into five chapters. Following the introduction, Chapter 2 focuses on previous studies on the bond strength of asphalt overlays. Chapter 3 outlines the research methodology and testing procedures used in the laboratory and field study of this report. Chapter 4 contains the results from the laboratory testing conducted as outline in Chapter 3. Chapter 5 finishes by drawing conclusions as a result of the outline testing procedure. The appendicies contain technical drawings, material procedures, results and calculations. 


\section{CHAPTER 2 LITERATURE REVIEW}

\subsection{INTRODUCTION}

A variety of testing devices are available for testing the bond strength of pavements. Three modes of loading are presented; tension devices, torque-shear devices, and direct shear devices. Based on the scope of this study, only results of direct shear type bond strength devices are presented in depth in the literature review. However, a short summary of the tension and torque devices is presented for completeness.

\subsection{TENSION AND TORQUE DEVICES}

Tension Bond strength devices have been evaluated by Raab and Partl (2004), Buchannan and Woods (2004), and Mohammad et al. (2009). Evaluations were performed on the ATACKer ${ }^{\mathrm{TM}}$, the University of Texas El Paso (UTEP) Simple Pull off Device (SPOD), the UTEP Pull Off Device, and the Louisiana Tack Coat Quality Tester (LTCQT). Torsional bond strength devices have been evaluated by Deysarkar, and Tandon (2004), and by several authors mention in NCHRP Report 712.

Raab and Partl (2004) used the Switzerland Pull-off Test on cores taken from 16 sites on the Swiss Motor ways. The sections consisted of full rehabilitation, partial rehabilitation, and no rehabilitation. At least 7 specimens were cored from each of the 16 sites and were tested at a temperature of $20^{\circ} \mathrm{C}$. The mean value for all 16 coring sites was $3.3 \pm 1.2 \mathrm{psi}$. According to the author, no significant difference in bond strength can be found between pavements with differing ages.

Buchannan and Woods (2004) evaluated three different emulsions, SS-1, CSS-1, and CRS-2 along with one performance grade binder, PG67-22, were evaluated using the prototype tack coat evaluation device (ATacker ${ }^{\mathrm{TM}}$ ). The author reported that the application rate and set time in fact had significant effects on the torque and tensile strength for dilution and non-dilution testing. In respect to the performance grade binder PG67-22, it was found that the tensile strength decreased with an increased application rate, inversely, the torque-shear strength increased with an increase in application rate. 
Mohammad et al. (2009) investigated three emulsified asphalt (CRS-1, SS-1h, and Trackless) and one asphalt cement (PG 64-22) using the LTCQT. Results indicated that the LTCQT can successfully determine the tensile strength of overlays in the field.

Deysarkar and Tandon (2004) reported using the UTEP Pull-off Device (UPOD) on both lab and field samples. The authors found that the bond strength doubled when temperature was increased from 48 to $64^{\circ} \mathrm{F}$ at an application rate of 0.04 gallons per square yard. For an application rate of 0.10 gallons per square yard, the strength was approximately 1.5 times that for the same temperature range.

\subsection{DIRECT SHEAR DEVICES}

Direct shear devices are commonly used for measuring pavement interface shear strength. Table 2 is a summary of the research using various direct shear devices. In addition, Gilson (Global Gilson 2013) and HMA lab Supply (HMA Lab Supply 2013) offer commercial direct shear loading heads but no literature was found using these devices. A direct shear device can be used with existing equipment, typically the Marshall Stabilometer, Figure 3.

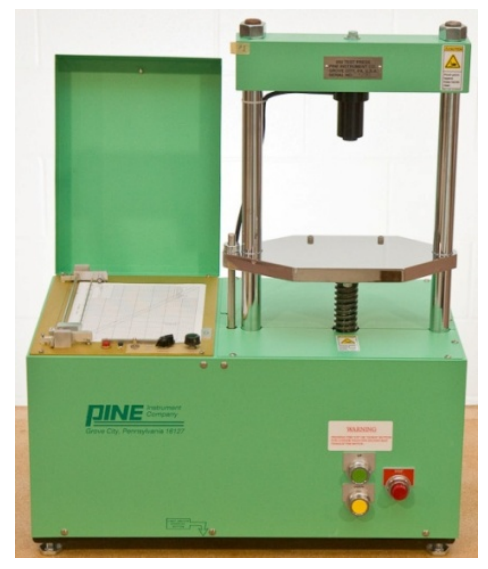

Figure 3: Marshall Stabilometer Loading Frame (Pine Instruments) 
Table 2: Summary of Direct Shear Bond Strength Devices

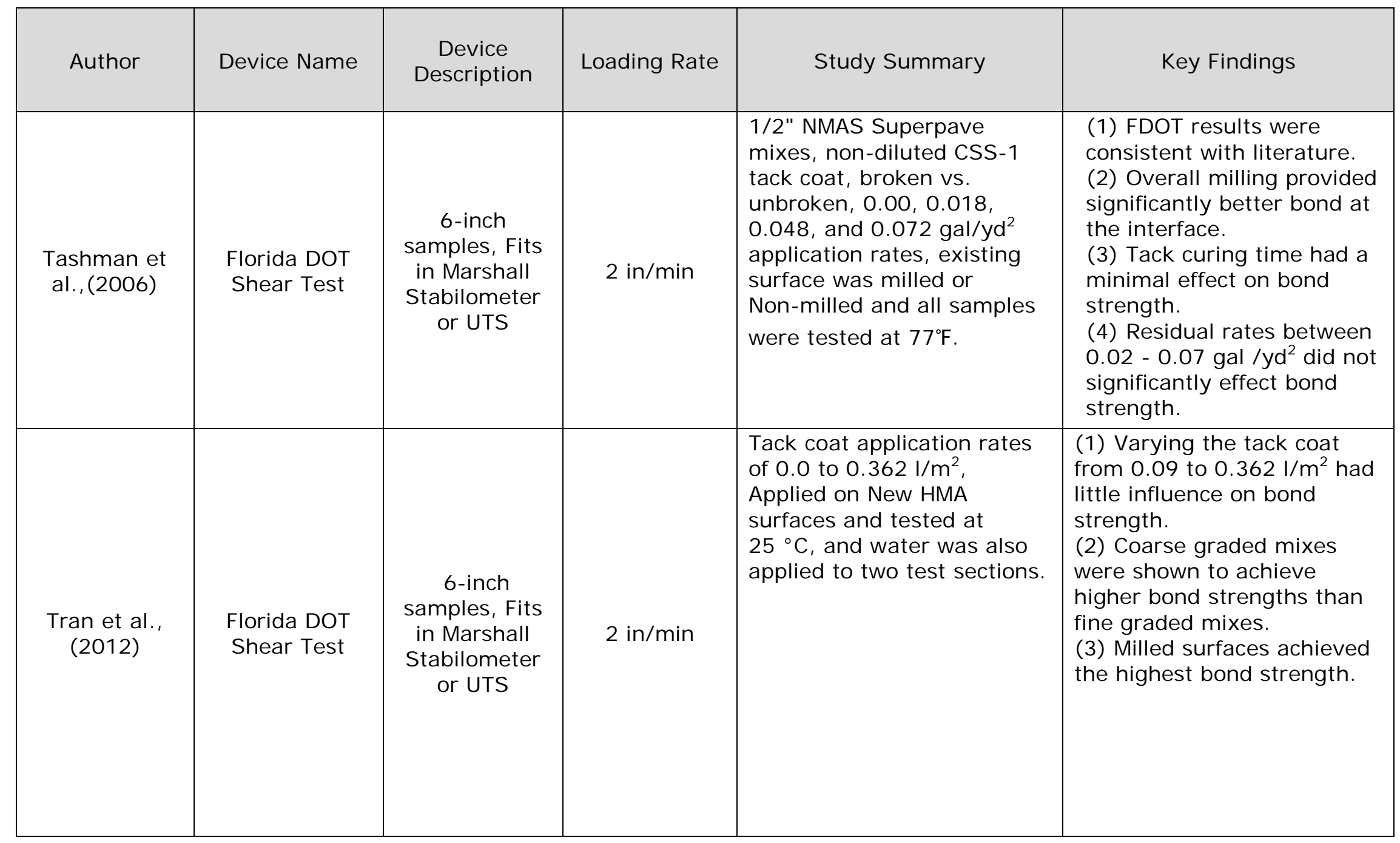




\begin{tabular}{|c|c|c|c|c|c|}
\hline Author & Device Name & $\begin{array}{c}\text { Device } \\
\text { Description }\end{array}$ & Loading Rate & Study Summary & Key Findings \\
\hline \multirow[b]{2}{*}{$\begin{array}{c}\text { Sholar et al., } \\
(2002)\end{array}$} & \multirow[b]{2}{*}{$\begin{array}{c}\text { Florida DOT } \\
\text { Shear Test }\end{array}$} & \multirow[b]{2}{*}{$\begin{array}{l}\text { Two Part } \\
\text { Study }\end{array}$} & \multirow[b]{2}{*}{$\mathrm{N} / \mathrm{A}$} & $\begin{array}{l}\text { Investigated the effects of } \\
\text { specimen diameter ( } 4 \text { or } 6 \\
\text { inch), mode of loading } \\
\text { (stress or strain controlled) } \\
\text { rate of loading } \\
(0.75 \text { or } 2.0 \text { in/min), testing } \\
\text { temperature ( } 77,100,120 \text {, } \\
\left.140^{\circ} \mathrm{F}\right) \text {, gap width between } \\
\text { shearing platens ( } 3 / 16 \text { th } \\
\text { inch). }\end{array}$ & $\begin{array}{l}\text { (1) } 6 \text { inch samples } \\
\text { (2) Strain controlled testing } \\
\text { (3) } 2.0 \text { in/min loading rate } \\
\text { (4) Testing temperature of } \\
77^{\circ} \mathrm{F} \text {. } \\
\text { (5) } 3 / 16 \text { inch gap width }\end{array}$ \\
\hline & & & & $\begin{array}{l}\text { Investigated three research } \\
\text { field projects (1) } 12.5 \mathrm{~mm} \\
\text { fine placed over } 12.5 \mathrm{~mm} \\
\text { fine. (2) } 12.5 \mathrm{~mm} \text { coarse } \\
\text { over } 19.0 \mathrm{~mm} \text { coarse. ( } 3 \text { ) } \\
12.5 \mathrm{~mm} \text { coarse over milled } \\
19 \mathrm{~mm} \text { coarse graded. }\end{array}$ & $\begin{array}{l}\text { (1) Water affects the } \\
\text { bonding of tack coat, yet } \\
\text { with time some increase was } \\
\text { shown but no comparable to } \\
\text { those fabricated without } \\
\text { water. } \\
\text { (2) Tack coat application } \\
\text { rate had slight effect on } \\
\text { shear strength. } \\
\text { (3) Fine graded mixes had } \\
\text { significantly lower strength } \\
\text { than coarse graded mix, } \\
\text { milling highest strength. } \\
\text { (4) Standard deviation of } \\
\text { test procedure determined } \\
\text { to be } 9.6 \text { psi, allowable } \\
\text { within laboratory difference } \\
\text { between two test results is } \\
27.2 \text { psi. }\end{array}$ \\
\hline $\begin{array}{l}\text { Tran et al. } \\
(2012) \\
\text { reported on } \\
\text { Sangiorgi et } \\
\text { al. }\end{array}$ & $\begin{array}{c}\text { Leutner Shear } \\
\text { Test }\end{array}$ & $\begin{array}{l}\text { 6-inch } \\
\text { Samples }\end{array}$ & $2 \mathrm{in} / \mathrm{min}$ & $\begin{array}{l}\text { Study evaluated the effects } \\
\text { of the use of emulsion with } \\
\text { or without a thin film of dirt } \\
\text { and tested at } 21^{\circ} \mathrm{C}\end{array}$ & $\begin{array}{l}\text { (1) Strongest bond } \\
\text { strengths were present with } \\
\text { the use of tack coat } \\
\text { emulsions }\end{array}$ \\
\hline
\end{tabular}




\begin{tabular}{|c|c|c|c|c|c|}
\hline Author & Device Name & $\begin{array}{c}\text { Device } \\
\text { Description }\end{array}$ & Loading Rate & Study Summary & Key Findings \\
\hline $\begin{array}{c}\text { Kim et al., } \\
(2011)\end{array}$ & $\begin{array}{l}\text { Layer Parallel } \\
\text { Direct Shear } \\
\text { (LPDS) }\end{array}$ & $\begin{array}{l}\text { 150-mm } \\
\text { cores, fits in } \\
\text { Marshall or } \\
\text { UTS }\end{array}$ & $2 \mathrm{in} / \mathrm{min}$ & $\begin{array}{l}\text { Mix types evaluated were } \\
\text { SMA 11, AC } 22, \text { AC } 32 \text {, and } \\
\text { AC S22, CAST samples were } \\
\text { tested at }-10,-5,0 \text {, } \\
-5,10,15,20,25,30,35 \text {, } \\
40^{\circ} \mathrm{C} \text { while the LPDS } \\
\text { samples were tested at } \\
-20 \text { and } 20^{\circ} \mathrm{C} \text {. }\end{array}$ & $\begin{array}{l}\text { (1) Both CAST and LPDS } \\
\text { demonstrate strong } \\
\text { influence of temperature on } \\
\text { interlayer bonding } \\
\text { mechanism. } \\
\text { ( } 2 \text { ) Low temperatures } \\
\text { increase bond strength. } \\
\text { (3) Full bond case can be } \\
\text { found at temperatures lower } \\
\text { than } 20 \text { Celsius. }\end{array}$ \\
\hline $\begin{array}{c}\text { Raab and } \\
\text { Partl (2004) }\end{array}$ & $\begin{array}{l}\text { Layer Parallel } \\
\text { Direct Shear } \\
\text { (LPDS) }\end{array}$ & $\begin{array}{l}\text { 150- } \mathrm{mm} \\
\text { cores, fits in } \\
\text { Marshall or } \\
\text { UTS }\end{array}$ & $2 \mathrm{in} / \mathrm{min}$ & $\begin{array}{l}\text { Supporting layer composed } \\
\text { of AC T } 22 \text { with Polymer } \\
\text { Modified Binder, Top layer } \\
\text { was AC } 11 \text { with Penetration } \\
\text { grade } 55 / 70 \text {. Thin film of } \\
2 \text { to } 4.5 \text { grams of } 20 \\
\text { different tack coats placed } \\
\text { on the non-cut side. } \\
\text { Samples compacted to } \\
\text { either } 50 \text { or } 204 \text { gyrations. }\end{array}$ & $\begin{array}{l}\text { (1) Samples with Cut face, } \\
\text { i.e. non sandblasted, } \\
\text { exhibited higher shear } \\
\text { strength than rough } \\
\text { surfaces. } \\
\text { (2) Samples without tack } \\
\text { coat and water introduced } \\
\text { had lower adhesion. }\end{array}$ \\
\hline $\begin{array}{l}\text { Sutradhar et } \\
\text { al. (2013) }\end{array}$ & $\begin{array}{l}\text { Layer Parallel } \\
\text { Direct Shear } \\
\text { (LPDS) }\end{array}$ & $\begin{array}{l}150-\mathrm{mm} \\
\text { cores, fits in } \\
\text { Marshall or } \\
\text { UTS }\end{array}$ & $2 \mathrm{in} / \mathrm{min}$ & $\begin{array}{l}\text { Mix types evaluated were } \\
\text { Bituminous Concrete (BC) } \\
\text { and Dense Bituminous } \\
\text { Macadam (DBM), tack coats } \\
\text { evaluated were CMS- } 2 \text { and } \\
\text { CRS-1, set until fully broken } \\
\text { at application rates of } 0.20 \\
\mathrm{~kg} / \mathrm{m}^{2}, 0.25 \mathrm{~kg} / \mathrm{m}^{2} \text { and } 0.30 \\
\mathrm{~kg} / \mathrm{m}^{2} \text {. The Existing Surface } \\
\text { was new HMA, and all } \\
\text { samples were tested at } \\
25^{\circ} \mathrm{C}\end{array}$ & $\begin{array}{l}\text { (1) Interface bonding is } \\
\text { weaker at lower applications } \\
\text { rates. } \\
\text { (2) Optimal application rate } \\
\text { of } 0.25 \mathrm{~kg} / \mathrm{m}^{2} \text { was found for } \\
\text { all tacks evaluated. } \\
\text { (3) CRS- } 1 \text { exhibited higher } \\
\text { bond strengths. } \\
\text { (4) Lab specimens } \\
\text { presented significantly } \\
\text { higher shear strengths } \\
\text { compared to field cored. }\end{array}$ \\
\hline
\end{tabular}




\begin{tabular}{|c|c|c|c|c|c|}
\hline Author & Device Name & $\begin{array}{c}\text { Device } \\
\text { Description }\end{array}$ & Loading Rate & Study Summary & Key Findings \\
\hline $\begin{array}{l}\text { West et } \\
\text { al.(2005) }\end{array}$ & $\begin{array}{l}\text { NCAT Bond } \\
\text { Strength } \\
\text { Device }\end{array}$ & $\begin{array}{c}0,10,20 \text { psi } \\
\text { Normal } \\
\text { Stress, } 6 \text { - } \\
\text { inch samples }\end{array}$ & $2 \mathrm{in} / \mathrm{min}$ & $\begin{array}{l}\text { Mix types evaluated were } \\
19-\mathrm{mm} \text { Coarse, } 4.75-\mathrm{mm} \\
\text { fine mixes with the } \\
\text { application of CRS-2, } \\
\text { CSS- } 1, \mathrm{PG} 64-22 \text { tack coat } \\
\text { at application rates of } 0.02 \text {, } \\
0.05,0.08 \mathrm{gal} / \mathrm{yd}^{2} \text { for PG } \\
64-22,0.04,0.08,0.12 \\
\text { gal/yd } \mathrm{yd}^{2} \text { for emulsions, tack } \\
\text { coat applied to New HMA } \\
\text { surfaces. Samples were } \\
\text { tested at } 50,77 \text { and } 140^{\circ} \mathrm{F}\end{array}$ & $\begin{array}{l}\text { (1) Fine graded exhibited } \\
\text { higher bond strengths } \\
\text { ( } 2 \text { ) PG } 64-22 \text { provided } \\
\text { higher bond strengths. } \\
\text { ( } 3 \text { ) Lower application rates } \\
\text { exhibited higher bond } \\
\text { strengths. } \\
\text { (4) Normal pressure } \\
\text { influenced more at higher } \\
\text { temperatures. } \\
\text { (5) Bond strengths on } \\
\text { average } 2.3 \text { times higher at } \\
50^{\circ} \mathrm{F} \text { compared to } 77^{\circ} \mathrm{F} \text {, while } \\
140^{\circ} \mathrm{F} \text { bond strengths were } \\
\text { one sixth that of } 77^{\circ} \mathrm{F}\end{array}$ \\
\hline $\begin{array}{c}\text { Al-Qadi et al. } \\
\text { (2008) }\end{array}$ & AL-Qadi Device & $\begin{array}{l}3.94 \text { inch } \\
\text { samples, } \\
\text { cyclic and } \\
\text { monotonic } \\
\text { testing }\end{array}$ & $0.47 \mathrm{in} / \mathrm{min}$ & $\begin{array}{l}\text { Mix types evaluated were } \\
\text { SM-9.5 surface mix and IM- } \\
19.5 \mathrm{~A} \text { binder mix, SS- } 1 \mathrm{~h} \\
\text { and SS- } 1 \mathrm{hP} \text { emulsions, and } \\
\text { RC- } 70 \text { cutback were } \\
\text { evaluated at application } \\
\text { rates of } 0,0.02,0.05, \\
0.09 \text { gal/yd } \mathrm{yd}^{2} \text { The existing } \\
\text { surface was Smooth, } \\
\text { Transverse Tinning, } \\
\text { Longitudinal Tinning, } \\
\text { milling, Samples were } \\
\text { tested at } 50,68,86^{\circ} \mathrm{F} \\
\text { Surface was either dry or } \\
\text { saturated. }\end{array}$ & $\begin{array}{l}\text { (1) SS-1h and SS-1hp } \\
\text { produce greater interface } \\
\text { bonding strength than } \\
\text { cutback asphalt RC- } 70 \text {. } \\
\text { (2) SM- } 9.5 \text { found to have } \\
\text { better interface strength. } \\
\text { (3) Optimum residual tack } \\
\text { coat application rate for SS- } \\
\text { 1hp using IM- } 19.0 \mathrm{~A} \text { binder } \\
\text { was } 0.04 \text { gal /yd }{ }^{2} \text {. } \\
\text { (4) Milling had the most } \\
\text { profound effect on interface } \\
\text { strength. }\end{array}$ \\
\hline
\end{tabular}




\begin{tabular}{|c|c|c|c|c|c|}
\hline Author & Device Name & $\begin{array}{c}\text { Device } \\
\text { Description }\end{array}$ & Loading Rate & Study Summary & Key Findings \\
\hline $\begin{array}{l}\text { Al-Qadi et } \\
\text { al.(2012)(a) } \\
\text { Part 1: Lab } \\
\text { Study }\end{array}$ & AL-Qadi Device & $\begin{array}{l}\text { Monotonic } \\
\text { testing }\end{array}$ & $\begin{array}{l}\text { constant load } \\
\text { or } \\
\text { displacement } \\
\text { rates }\end{array}$ & $\begin{array}{l}\text { Mixes evaluated were } 4.75 \\
\text { mm and } 9.5 \text { mm NMAS, } \\
\text { Tack coats evaluated were } \\
\text { SS-1hp, SS- } 1 \mathrm{vh}, \mathrm{HFE} \text {, and } \\
\text { PG } 64-22,0.25,2, \text { and } 24 \\
\text { hr. set times, } 0,0.02,0.04 \text {, } \\
0.06 \text {, and } 0.08 \mathrm{gal} / \mathrm{yd}^{2} \\
\text { application rates, existing } \\
\text { surface was unmilled aged } \\
\text { nontrafficked, milled aged, } \\
\text { and unmilled aged } \\
\text { trafficked, All samples were } \\
\text { tested at either } 5^{\circ} \mathrm{F}, 41^{\circ} \mathrm{F} \text {, } \\
77^{\circ} \mathrm{F} \text {, and } 113^{\circ} \mathrm{F} \text {. }\end{array}$ & $\begin{array}{l}\text { (1) Optimum residual rate } \\
\text { for trafficked and } \\
\text { nontrafficked unmilled aged } \\
\text { surfaces is } 0.04 \text { gal } / \mathrm{yd}^{2} \text {. } \\
\text { (2) Optimum residual rate } \\
\text { for milled is } 0.06 \text { gal/yd }{ }^{2} \text {. } \\
\text { (3) SS-1vh showed superior } \\
\text { performance over other tack } \\
\text { coats. } \\
\text { (4) Milling increases shear } \\
\text { resistance. } \\
\text { (5) Larger NMAS increased } \\
\text { shear resistance. } \\
\text { (6) Increased temperature } \\
\text { reduces shear strength. } \\
\text { (7) Optimum curing time } \\
\text { was found to be } 2 \text { hours. }\end{array}$ \\
\hline $\begin{array}{l}\text { Al-Qadi et al., } \\
\text { (2012)(b) } \\
\text { Part 2: Field } \\
\text { Study }\end{array}$ & AL-Qadi Device & $\begin{array}{l}\text { Monotonic } \\
\text { testing }\end{array}$ & $\begin{array}{l}\text { constant load } \\
\text { or } \\
\text { displacement } \\
\text { rates }\end{array}$ & $\begin{array}{l}\text { Polymer SMA } 12.5-\mathrm{mm} \\
\text { surface mix N80 mix types } \\
\text { evaluated, SS-1h, SS-1hp, } \\
\text { and SS- } 1 \text { vh (non-track tack } \\
\text { coat) tack coats, SS-1h and } \\
\text { SS-1hp set for } 24 \text { hrs. SS- } \\
1 \text { vh set for } 30 \text { minutes, } \\
0.02,0.04,0.06 \text {, and } 0.08 \\
\text { gal/yd } 2 \text { application rates, } \\
\text { milled HMA, milled Portland } \\
\text { cement concrete, binder } \\
\text { stone mastic asphalt, } \\
\text { tested at } 77^{\circ} \mathrm{F}\left(25^{\circ} \mathrm{C}\right) \text {., } \\
\text { surface cleaned with broom, } \\
\text { vacuum and air-blast } \\
\text { cleaning }\end{array}$ & $\begin{array}{l}\text { (1) Similar bond strengths } \\
\text { between cleaning methods. } \\
\text { (2) Bond strength at } \\
\text { interface when tack was } \\
\text { applied with spray paver } \\
\text { achieved higher bond } \\
\text { strength. } \\
\text { (3) Optimum residual rate } \\
\text { for milled surfaces from lab } \\
\text { were } 0.06 \mathrm{gal} / \mathrm{yd}^{2} \text {, validated } \\
\text { on both test sites } \\
\text { (4) SS-1vh performed better } \\
\text { than any tack coat studied. }\end{array}$ \\
\hline
\end{tabular}




\begin{tabular}{|c|c|c|c|c|c|}
\hline Author & Device Name & $\begin{array}{c}\text { Device } \\
\text { Description }\end{array}$ & Loading Rate & Study Summary & Key Findings \\
\hline $\begin{array}{l}\text { Chen and } \\
\text { Huang } \\
(2010)\end{array}$ & $\begin{array}{c}\text { Direct Shear } \\
\text { Device (Similar } \\
\text { to } \\
\text { Geotechnical) }\end{array}$ & $\begin{array}{l}\text { Capable of } \\
\text { normal load }\end{array}$ & $0.1 \mathrm{in} / \mathrm{min}$ & $\begin{array}{l}\text { DGAC-DGAC, PAC-DGAC, } \\
\text { and PAC-SMA mix types } \\
\text { evaluated, CRS emulsion, } \\
\text { MAE, non-track coat, } \\
\text { samples compacted } 24 \text { hour } \\
\text { apart, cured for } 15 \text { days } \\
\text { prior to testing, } 0.06,0.12 \text {, } \\
0.18,0.24 \text {, and } 0.3 \mathrm{~L} / \mathrm{m}^{2} \\
\text { application rates. Existing } \\
\text { surface was new } \mathrm{HMA} \\
\text { tested at } 25^{\circ} \mathrm{C}, 35^{\circ} \mathrm{C} \text {, and } \\
50^{\circ} \mathrm{C} \text {. }\end{array}$ & $\begin{array}{l}\text { (1) Curing time has an effect } \\
\text { on bond strength. } \\
\text { ( } 2 \text { ) Use of tack coat } \\
\text { increased the interface bond } \\
\text { strength. } \\
\text { ( } 3 \text { ) Surface characteristics } \\
\text { had more of an effect on } \\
\text { bond strength at higher } \\
\text { temperatures. }\end{array}$ \\
\hline $\begin{array}{l}\text { McGhee and } \\
\text { Clark } \\
(2009)\end{array}$ & $\begin{array}{l}\text { Virginia DOT } \\
\text { Device }\end{array}$ & $\begin{array}{c}6 \text { inch } \\
\text { samples, Fits } \\
\text { in Marshal } \\
\text { Stability } \\
\text { device }\end{array}$ & $2 \mathrm{in} / \mathrm{min}$ & $\begin{array}{l}\text { New HMA over Milled } \\
\text { Pavement evaluated using } \\
\text { CRS-2, CSS-1h, and non- } \\
\text { tracking tack (NTT), } \\
15 \text { minute set time with } \\
\text { application rates of } 0.075 \\
\text { gal/yd }{ }^{2} \text {, Existing surface } \\
\text { milled and samples were } \\
\text { tested at } 50,68,86 \mathrm{~F} \text {. }\end{array}$ & $\begin{array}{l}\text { (1) Bond strength between } \\
\text { new HMA overlay and a } \\
\text { milled underlying surface is } \\
\text { not affected by the } \\
\text { application of tack coat. } \\
\text { (2) CSS-1h produced } \\
\text { highest average strength in } \\
\text { lab. }\end{array}$ \\
\hline
\end{tabular}




\begin{tabular}{|c|c|c|c|c|c|}
\hline Author & Device Name & $\begin{array}{c}\text { Device } \\
\text { Description }\end{array}$ & Loading Rate & Study Summary & Key Findings \\
\hline $\begin{array}{l}\text { Bae et al., } \\
(2010)\end{array}$ & $\begin{array}{c}\text { Louisiana } \\
\text { Interlayer } \\
\text { Shear Strength } \\
\text { Tester, (LISST) }\end{array}$ & $\begin{array}{l}6 \text { - inch cores, } \\
\text { capable of } 100 \\
\text { psi normal } \\
\text { load }\end{array}$ & $0.1 \mathrm{in} / \mathrm{min}$ & $\begin{array}{l}\text { Evaluated CRS- } 1 \text {, Trackless } \\
\text { tack coats at application } \\
\text { rates of } 0.14,0.28 \text {, } \\
0.70 \mathrm{l} / \mathrm{m}^{2}, \\
\text { testing temperature } \\
\text { between }-10 \text { to } 60^{\circ} \mathrm{C}\end{array}$ & $\begin{array}{l}\text { (1) Trackless tack was } \\
\text { brittle at low temperatures. } \\
\text { ( } 2 \text { ) Trackless tack was found } \\
\text { to be superior to CRS-1 } \\
\text { emulsion, especially at } \\
\text { temperatures greater than } \\
40^{\circ} \mathrm{C} \text {. } \\
(3) \text { Interface shear strength } \\
\text { (ISS) increases with the } \\
\text { increase of } G^{*} / \sin (\delta)\end{array}$ \\
\hline $\begin{array}{l}\text { Mohammad et } \\
\text { al.,(2011) }\end{array}$ & $\begin{array}{c}\text { Louisiana } \\
\text { Interlayer } \\
\text { Shear Strength } \\
\text { Tester, (LISST) }\end{array}$ & $\begin{array}{l}6 \text { - inch cores, } \\
\text { capable of } 100 \\
\text { psi normal } \\
\text { load }\end{array}$ & $0.1 \mathrm{in} / \mathrm{min}$ & $\begin{array}{l}\text { New overlay on an existing } \\
\text { HMA Surface, CRS-1, SS- } \\
\text { 1h, trackless, and PG } 64- \\
\text { 22, samples cure for } 4 \\
\text { hours prior to testing, } \\
0.031,0.062 \text {, and } .155 \\
\text { gal/yd }{ }^{2}, \text { Tested at } 25^{\circ} \mathrm{C}\end{array}$ & $\begin{array}{l}\text { ( } 1 \text { ) Influence of tack coat } \\
\text { material and time is more } \\
\text { relevant in thin overlays. } \\
\text { (2) Minimum measured } \\
\text { interface shear strength to } \\
\text { provide acceptable fatigue } \\
\text { was } 190 \mathrm{kPa}(27.6 \mathrm{psi}) \text { for } \\
\text { thin overlays, and } 128 \mathrm{kPa} \\
\text { ( } 18.6 \mathrm{psi} \text { ) for thick overlays. }\end{array}$ \\
\hline
\end{tabular}




\begin{tabular}{|c|c|c|c|c|c|}
\hline Author & Device Name & $\begin{array}{c}\text { Device } \\
\text { Description }\end{array}$ & Loading Rate & Study Summary & Key Findings \\
\hline $\begin{array}{l}\text { Mohammad et } \\
\text { al., (2012) }\end{array}$ & $\begin{array}{c}\text { Louisiana } \\
\text { Interlayer } \\
\text { Shear Strength } \\
\text { Tester, (LISST) }\end{array}$ & $\begin{array}{l}6 \text { - inch cores, } \\
\text { capable of } 100 \\
\text { psi normal } \\
\text { load }\end{array}$ & $0.1 \mathrm{in} / \mathrm{min}$ & $\begin{array}{l}\text { 12.5-mm NMAS HMA mix } \\
\text { type evaluated with either } \\
\text { SS-1h, SS-1, CRS-1, } \\
\text { Trackless, PG } 64-22, \\
\text { (No-Tack), } 0.031,0.062 \text {, } \\
0.155-\text { gal/yd } d^{2}, \text { Old HMA, } \\
\text { New HMA, PCC, Milled HMA, } \\
\text { Tested at } 25^{\circ} \mathrm{C} \text {, Surface } \\
\text { condition prior to overlay } \\
\text { was Wet, Dry, Dusty, Clean. } \\
\text { Samples were tested with } \\
\text { either } 0 \text { or } 20 \text { psi normal } \\
\text { pressure. }\end{array}$ & $\begin{array}{l}\text { (1) Trackless tack exhibited } \\
\text { highest shear strength. } \\
\text { (2) CRS-1 exhibited lowest. } \\
\text { (3) Highest shear strength } \\
\text { for all tack materials at a } \\
\text { residual rate } \\
\text { of } 0.155 \text { gal/yd }{ }^{2} \text {. } \\
\text { (4) Non-confinement testing } \\
\text { exhibits conservative } \\
\text { estimates of the ISS values. } \\
\text { (5) Dusty conditions } \\
\text { exhibited higher strength. } \\
\text { (6) No statistical difference } \\
\text { between wet and dry } \\
\text { conditions. } \\
\text { ( } 7) \text { Minimum bond strength } \\
\text { for acceptable performance } \\
\text { is } 40 \text { psi }\end{array}$ \\
\hline $\begin{array}{c}\text { Hakimzadeh, } \\
\text { et al, } \\
\text { (2012) }\end{array}$ & $\begin{array}{c}\text { Interface Bond } \\
\text { Test }\end{array}$ & $\begin{array}{l}6-\text { inch } \\
\text { samples }\end{array}$ & $\mathrm{N} / \mathrm{A}$ & $\begin{array}{l}\text { 19-mm NMAS mix design } \\
\text { was evaluated with } \\
\text { Trackless, CSS-1hp, PMAE } \\
\text { tack coats. Two hour set } \\
\text { time was evaluated with } \\
\text { application rates of } 0,0.02 \text {, } \\
0.05,0.1,0.12 \text {, and } 0.15 \\
\text { gal/yd }{ }^{2}, \text { New HMA surface } \\
\text { tested at '- } 12,0,12,25 \mathrm{C} \text {. }\end{array}$ & $\begin{array}{l}\text { (1) Optimum tack coat } \\
\text { application rate obtained } \\
\text { from shear test is difference } \\
\text { than optimum tack coat } \\
\text { application rate from tension } \\
\text { test. } \\
\text { (2) Trackless tack exhibits } \\
\text { stronger bond than SS-1hp } \\
\text { (3) SS-1hp tack is better at } \\
\text { low temperatures. } \\
\text { (4) Curing time affected } \\
\text { tensile bond strength of } \\
\text { overlays, less curing time } \\
\text { showed better strength. }\end{array}$ \\
\hline
\end{tabular}




\begin{tabular}{|c|c|c|c|c|c|}
\hline Author & Device Name & $\begin{array}{c}\text { Device } \\
\text { Description }\end{array}$ & Loading Rate & Study Summary & Key Findings \\
\hline $\begin{array}{l}\text { Kruntcheva et } \\
\text { al., (2006) }\end{array}$ & $\begin{array}{c}\text { Direct shear } \\
\text { (see reference) }\end{array}$ & $\mathrm{N} / \mathrm{A}$ & $\mathrm{N} / \mathrm{A}$ & $\begin{array}{l}\text { 35-14 Hot Rolled Asphalt } \\
\text { evaluated using } \mathrm{K} 1-40 \text { tack } \\
\text { coat applied at } 0.33 \mathrm{~L} / \mathrm{m}^{2} \\
\text { and } 1.0 \mathrm{l} / \mathrm{m}^{2} \text { or no tack. } \\
\text { Clay water slurry was used } \\
\text { to simulate dirty conditions. }\end{array}$ & $\begin{array}{l}\text { (1) Interface properties } \\
\text { depend on type of materials, } \\
\text { not amount of tack. } \\
\text { (2) Dry clean surface } \\
\text { exhibits similar properties to } \\
\text { same interface with quality } \\
\text { tack coat. }\end{array}$ \\
\hline $\begin{array}{c}\text { Miro } \\
\text { Recasens, } \\
\text { Rodrigo et al } \\
(2003)\end{array}$ & $\begin{array}{l}\text { Loboratorio de } \\
\text { Caminos de } \\
\text { Barcelona } \\
\text { (LCB) Shear } \\
\text { Test }\end{array}$ & $\begin{array}{l}100 \mathrm{~mm} \\
\text { cylinders, no } \\
\text { normal force, } \\
\text { static test }\end{array}$ & $1.27 \mathrm{~mm} / \mathrm{min}$ & $\begin{array}{l}\text { Studied four hard residual } \\
\text { heat-adhesive emulsions, } \\
\text { two conventional } \\
\text { (HAW-1 and HAE-2), two } \\
\text { modified, and one Rapid } \\
\text { Setting Cationic Emulsion, } \\
\text { applied at } 350 \mathrm{~g} / \mathrm{m}^{2}\end{array}$ & $\begin{array}{l}\text { (1) In general, heat- } \\
\text { adhesive emulsions show } \\
\text { less adhesion ability at lower } \\
\text { temperatures }\left(-15^{\circ} \mathrm{C}\right) \text {, but } \\
\text { show better adhesion at } 5 \text { to } \\
20^{\circ} \mathrm{C} \text {. } \\
\text { (2) Rapid Setting Emulsion } \\
\text { gains strength with time, } \\
\text { while heat-adhesive loses } \\
\text { strength with age. }\end{array}$ \\
\hline
\end{tabular}


Based on the literature summarized in Table 2 the following characteristics were investigated by multiple authors:

1. Mix types

2. Surface Characteristics

3. Tack Coat Type

4. Tack Coat Application Rate

5. Testing Temperature

6. Testing Confinement

7. Curing Time or Setting Time

8. Laboratory and Field Samples

9. Effect of Conditioning

\subsection{TYPES}

Sholar et al., (2002) stated fine graded mixes exhibited lower bond strengths than coarse graded mixes, and Tran, et al. (2012) found coarse graded mixes exhibited higher bond strengths than fine graded mixes. West et al. (2005) found tack coat had a greater influence on the bond strength of fine graded mixes than coarse graded mixes, and contrary to Sholar et al. Al-Qadi, et al. (2008), found a Stone Mastic $9.5 \mathrm{~mm}$ mix had higher bond strengths than a $19.5 \mathrm{~mm}$ mix when placed over PCC. Also Al-Qadi et al. (2012a) found that increasing the nominal maximum aggregate size (NMAS) from $4.75 \mathrm{~mm}$ to $9.5 \mathrm{~mm}$ increased the bond strength.

\section{5 SURFACE CHARACTERISTICS}

Sholar et al. (2002), Tashman et al. (2006), Tran et al. (2012), Al-Qadi et al. (2008, 2012a, 2012b), all found milled surfaces tend to exhibit higher shear bond strength than nonmilled surfaces. Raab and Partl (2004) stated that a cut interface produces higher bond strengths than new HMA surfaces. Moisture significantly decreased the bond strength (Tran, et al, 2012 and Al-Qadi et al., 2008), inversely; Raab and Partl. (2004) reported that the presence of water at the interface produced better adhesion. Mohammad et al. (2012) found there was no statistical difference due to moisture. 


\subsection{TACK COAT}

West et al., (2005) reported that a PG 64-22 achieved higher bond strength than CRS-2 and CSS-1. Al-Qadi et al., (2008, 2012a, 2012b) found SS-1h and SS-1hp and SS-1vh (a trackless tack) exhibited the highest bond strengths compared to other tack coats materials. McGhee and Clark (2009) reported CSS-1h emulsion achieved the higher bond strength in laboratory specimens than to CRS-2 and Trackless Tack. Bae et al. (2010), Hakimzadeh et al. (2012) and Mohammad et al. (2012) reported that Trackless tack produced higher bond strengths the conventional emulsions. Sutradhar et al., (2013) reported that a CRS-1 emulsion exhibited higher bond strengths than a CMS-2 emulsion.

Tashman et al. (2006) found the absence of tack coat at the interface of a milled surface did not affect bond strength, whereas it severely decreased the strength of non-milled sections. Hakimzadeh, et al. (2012) found higher bond strengths in specimens fabricated with tack coat. AL-Qadi et al. (2008 and 2012a,) found that the absence of tack coat produced lower results compared to samples with tack coat. Mohammad et al. (2012) stated that for a new, smooth surface, tack coats act as a lubricant, thus decreasing the shear strength at the interface. McGhee and Clark (2009) found the bond strength did not appear to be affected by the presence of tack material.

\section{7 TACK COAT APPLICATION RATE}

Al-Qadi et al. (2008) reported the optimum residual tack coat application rate for a 19.0 mm binder mix using SS-1hp tack coat was 0.04 gallons per square yard. Al-Qadi et al. (2012b) found the optimum residual application rate for trafficked and non-trafficked milled surfaces was 0.04 gallons per square yard. For milled surfaces the optimum residual application rate was 0.06 gallons per square yard. Buchanan and Woods (2004) reported that when tack coats are not fully broken the optimum residual application rate is 0.05 gallons per square yard, and when tack coats are fully broken the optimum application rate was 0.09 gallons per square yard. Sutradhar et al., (2013) found the optimum application rate for all tack coats in his study was 0.06 gallons per square yard.

Mohammad et al. (2012) reported that the optimum residual application rate, based on bond strength, for various surfaces was: 
1. New Asphalt Surface -0.035 gallons per square yard

2. Old Asphalt Surface -0.055 gallons per square yard

3. Milled Asphalt Surface -0.055 gallons per square yard

4. Portland Cement Concrete Surface -0.045 gallons per square yard

\subsection{TEST TEMPERATURE}

Deysarkar and Tandon (2004) found at an tack coat application rate of 0.10 gallons per square yard, the strength increased by a factor of 3 when the temperature was increased from 40 to $68 \mathrm{~F}$, while at an application rate of 0.04 gallons per square yard the strength increased by a factor between 1.3 and 2.0. West et al. (2005) and Al-Qadi et al, (2012a) reported that the bond strength significantly decreased at higher temperatures. Kim et al., (2011) found temperature has a strong influence on the bonding mechanism, and testing at lower temperatures increased the bond strength. West et al. (2005) and Sholar et al. (2002) recommend a test temperature of $77^{\circ} \mathrm{F}$.

\subsection{TESTING CONFINEMENT}

West et al., (2005) found that testing with a normal stress has a larger effect at higher temperatures than at lower temperatures. Testing under confinements has been shown to increase the bond strength results. Mohammad et al. (2012) stated that testing without confinement is a conservative approach to the bond strength.

\subsection{SETTING TIME}

Deysarkar and Tandon (2004) reported the strength gain is exponentially dependent on set time based on 30, 45, and 60 minute set times. Al-Qadi et al. (2012a) found the optimum curing time was 2 hours. Tran et al., (2012) cured samples for 0, 1, and 6 hours, and found that a longer cure time resulted in higher bond strength. Hakimzadeh (2012) cured samples for 0 or 2 hours and reported less curing time showed better strength.

\section{11 LABORATORY VERSUS FIELD SAMPLES}

Laboratory fabricated samples exhibit higher bond strengths than samples extracted from the field, (Sutradhar et al. (2013) and Tran et al. (2012). Other researchers tested both laboratory and field samples but did not make the comparative statements concerning the bond strength. 


\subsection{EFFECT OF CONDITIONING}

Taylor and Willis (2012) and. Al-Qadi et al. (2008) found conditioning the sample per AASHTO T283 can significantly reduce the interface shear strength between HMA overlays or PCC pavements.

\section{13 GUIDELINES FOR PROPOSING A BOND STRENGTH TESTING PROCEDURE}

As a result of a thorough review of the literature, two standardized material procedures for determining the bond strength of asphalt pavements utilizing a direct shear device were found. The Alabama Department of Transportation Material Procedure ALDOT-430 defines the state's procedure for determining the bond strength of pavements. The Virginia Department of Transportation (VDOT) also has a standardized laboratory test procedure for determining the bond strength of asphalt layers, named Virginia Test Method - 128. This method, similar to ALDOT - 430 includes both direct shear testing and tension testing. However, the VDOT procedure is not as detailed as the ALDOT procedure.

\subsection{MINIMUM BOND STRENGTH RECOMMENDATIONS}

Tran et al. (2012) used Bisar, an elastic layer theory program, to identify a minimum bond strength criterion. He suggested that at 0.5 inches below the pavement surface subject to a 20 kip load, 100 psi tire pressure, and 0.8 friction coefficient the maximum stress is 92 psi. Wang et al. (2010) used ABAQUS, a finite element program, to develop the following table, with slight modifications to convert from $\mathrm{kPa}$ to psi.

The maximum longitudinal stress the pavement is subjected to is $133 \mathrm{psi}$. This occurs in a full brake condition with a friction coefficient of 0.8 . The pavement was subjected to a 4000 pound load with a 100 psi tire pressure, equivalent to an 18-kip dual tire axle. Mohammad et al. (2012) suggested that $40 \mathrm{psi}$ is acceptable bond strength for asphalt overlays, based on a finite element model. Solainanian (2013), stated an average shear strength of 45 psi is considered acceptable. 
Table 3: Maximum Contact Stresses with Different Friction Coefficients (Wang et al., 2010)

\begin{tabular}{|c|c|c|c|c|}
\hline \multirow{2}{*}{$\begin{array}{c}\text { Rolling } \\
\text { Conditions }\end{array}$} & $\begin{array}{c}\text { Friction } \\
\text { Coefficients }\end{array}$ & \multicolumn{3}{|c|}{$\begin{array}{c}\text { Maximum Contact Stresses } \\
\text { (psi) }\end{array}$} \\
\cline { 3 - 5 } & & Vertical & Transverse & Longitudinal \\
\hline \multirow{2}{*}{$\begin{array}{c}\text { Free } \\
\text { Rolling }\end{array}$} & 0.3 & 153 & 32 & 9 \\
\cline { 2 - 5 } & 0.5 & 153 & 45 & 11 \\
\cline { 2 - 5 } & 0.8 & 155 & 57 & 12 \\
\hline \multirow{2}{*}{$\begin{array}{c}\text { Full } \\
\text { Braking }\end{array}$} & 0.3 & 153 & 2 & 46 \\
\cline { 2 - 5 } & 0.5 & 160 & 6 & 80 \\
\hline \multirow{3}{*}{ Cornering } & 0.8 & 166 & 11 & 133 \\
\cline { 2 - 5 } & 0.3 & 168 & 40 & 11 \\
\cline { 2 - 5 } & 0.5 & 189 & 58 & 12 \\
\hline
\end{tabular}

\subsection{KEY FINDINGS FROM THE LITERATURE REVIEW}

Since the objective of this research was to assist the WV DOH with the development of a test method and criteria for quality control, the following key points are summarized from the literature:

1. Direct shear testing is the most common method of interface bond strength testing.

2. The Marshall Stabilometer is a common load frame for testing with a direct shear device.

3. Temperature affects the test results. A common test temperature is $77^{\circ} \mathrm{F}$

$\left(25^{\circ} \mathrm{C}\right)$ which is a convenient temperature for testing in an asphalt lab.

4. Most researchers used shop build testing devices. There are two commercially available shear test loading heads but there are no published reports in the literature on the use of these devices.

5. The ALDOT material procedure is the most thorough test method published by a state highway agency. 
6. Samples fabricated in the lab were made in two steps, first the supporting layer was made, tack coat was applied, and then the top layer was compacted. However, the specific details of the process were not provided.

7. Lab samples exhibited higher bond strengths than field cored samples.

8. The conclusions reached by different researchers were inconsistent in several areas. 


\section{CHAPTER 3 RESEARCH METHODOLOGY}

\subsection{INTRODUCTION}

The objective of this research study was to investigate the bond strength of asphalt overlays. This research study investigated the development of a new bond strength testing device and a standardized testing procedure. Laboratory and field testing was performed to evaluated the proposed testing device.

\subsection{DEVELOPMENT OF BOND STRENGTH TESTING DEVICE}

Based on the literature review a direct shear device was designed and fabricated. The device is similar in concept to the one used by NCAT (West et al., 2005). ALDOT uses a device modeled on the NCAT device. Based on information from the West et al. report a device was fabricated for the WVDOH. It is a direct shear device designed for 6” cores or $150 \mathrm{~mm}$ laboratory prepared samples. The shear gap is $1 / 4$ ”. A clamp is used to secure the sample to the fixed position of the device. The shear force is provided with a Marshall Stabilometer. The device is shown in Figure 4 and the technical drawings are in Appendix 1.

\subsection{DEVELOPMENT OF BOND STRENGTH TESTING PROCEDURE}

The WVDOH, prior to this study, had no standard method for bond strength testing. Based on the literature, a test method was modeled off information presented by West et al., (2005). This test method has been adopted by the Alabama Department of Transportation as ALDOT - 430. A recommended procedure for the WVDOH is in Appendix 2. In the ALDOT 430, the results are reported to the nearest $50 \mathrm{lbf}$ and to the nearest psi. Since the method proposed for the WVDOH recommends using 10,000 pound recording paper in the Marshall Stabilometer, the reading of the maximum force can only be accurate to \pm 100 pounds. If the precision of the test method is governed by a load measurement of \pm 100 pounds, the accuracy of the bond strength, in psi, is \pm 3.5 psi, assuming a $150 \mathrm{~mm}$ diameter sample. A $150 \mathrm{~mm}$ diameter sample is the standard Superpave sample size. 


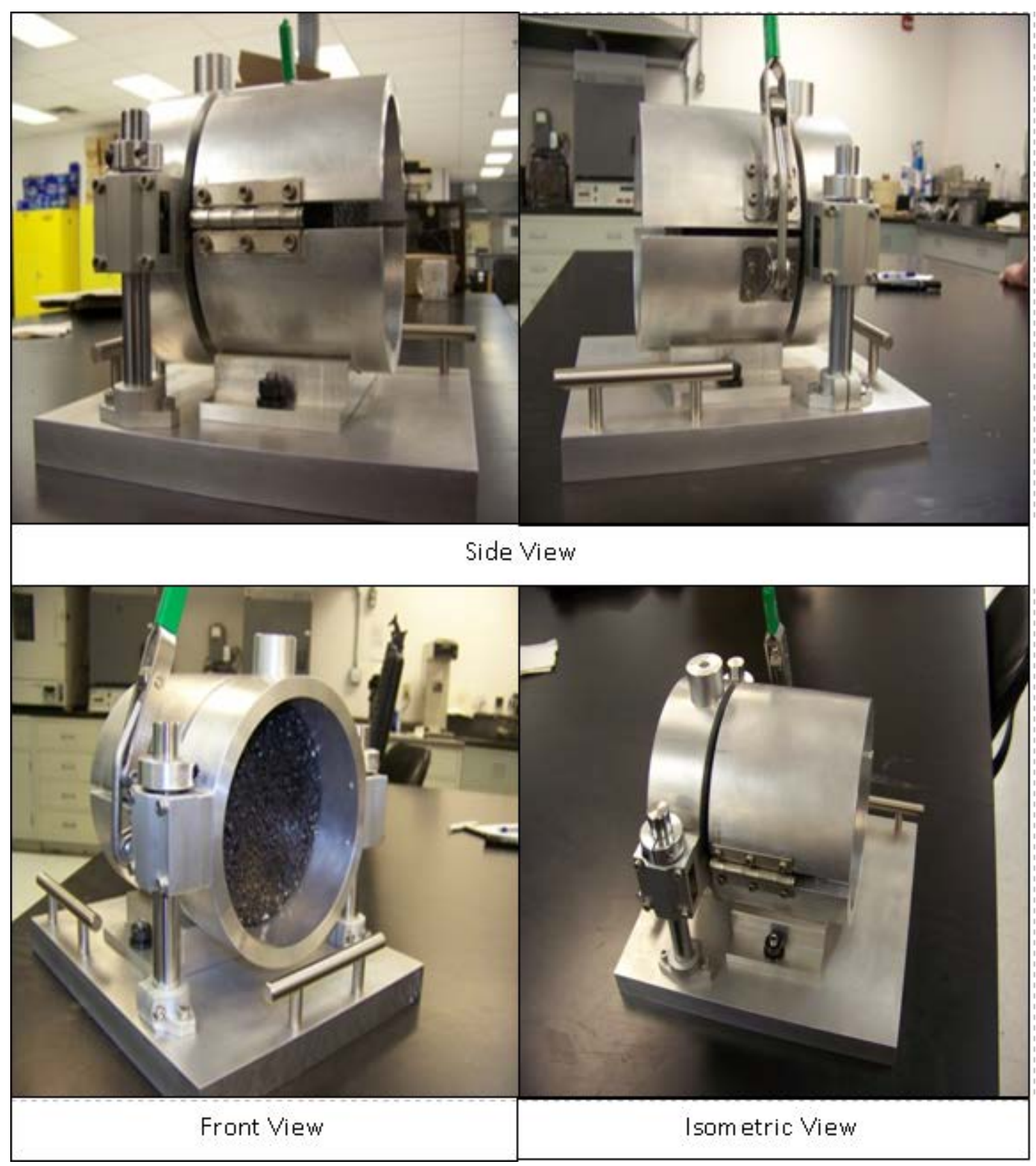

Figure 4: WV DOH Shear Device

\subsection{DEVELOPMENT OF A LABORATORY SAMPLE PREPARATION PROCEDURE}

The ALDOT test method was developed for measuring the interface bond strength of cores obtained from the field; a protocol must be established for preparing laboratory samples. Issues that need to be resolved for laboratory samples are: 
- Method of preparing the "support layer"; the portion of the sample that mimics the "original" or "existing" pavement in the core

- Method of preparing the surface of the support layer; simulating an oxidized or milled surface

- Compaction method for the "top layer"; the portion of the sample that mimics the overlay

- Rest period between sample preparation and testing.

Tests were performed to determine if it was possible to compact half height $(57.5 \mathrm{~mm})$ samples, using the contractors mix design. The air voids of the resulting samples were very inconsistent. It was decided to compact full height samples, using 80 gyrations, and cut them in half to provide the samples for the supporting layer. This provided support layer samples with 4 \pm 1 percent air voids since the support layer mixes were replicates of the material used for the mix design.

For the samples intended to simulate an overlay on an existing asphalt surface, the top layer can be molded to either the freshly molded face or to the cut face of the pill. Tests on a couple of samples made by molding the surface layer onto the fresh surface produced abnormally high results. Tests on samples molded to the cut face of the support sample produced results that were more consistent with published results. It was decided that the cut face of the support layer pill would be used for the interface surface for all existing surface samples since this would replicate a highly trafficked surface where the asphalt film has been removed from the surface.

The experimental plan included testing on milled surfaces. To simulate the effects of milling an HMA surface in a laboratory, the macrotexture of a milled surface needed to be quantified. This was performed on a milled section of Mileground Road in Morgantown, WV. The mean texture depth of the milled pavement was determined by ASTM E965-06 Standard Test Method for Measuring Pavement Macrotexture Depth Using a Volumetric Technique, with one exception, the specific gravity of the beads was determined so that the mass of the beads occupying the surface voids could be used instead of the volume. Using the mass and density of the glass beads, the Mean Texture Depth (MTD) was determined using the following equations: 
$V=\frac{\text { Mass }}{\rho} \times 10^{3}$

Where:

Mass $=$ mass of beads occupying surface voids, grams,

$\rho=2.471 \mathrm{~g} / \mathrm{cm}^{3}$

$\operatorname{MTD}=\frac{4 \mathrm{~V}}{\pi \mathrm{D}^{2}}$

Where:

$\mathrm{V}=$ sample volume in $\mathrm{mm}^{3}$

$\mathrm{D}=$ diameter, $\mathrm{mm}$.

The measured texture of the Mileground pavement was $2.94 \mathrm{~mm}$. The pavement evaluated had an extremely coarse texture and was only measured because it was convenient and could be used for setting an upper limit for the texture of the laboratory prepared samples. An angle grinder was used to cut a grid pattern on a sample prepared with the SGC, Figure 5. This sample had a macrotexture of $1.3 \mathrm{~mm}$. Any attempt to increase the macrotexture further could lead to deterioration of the surface that could affect the interface shear strength measurements.

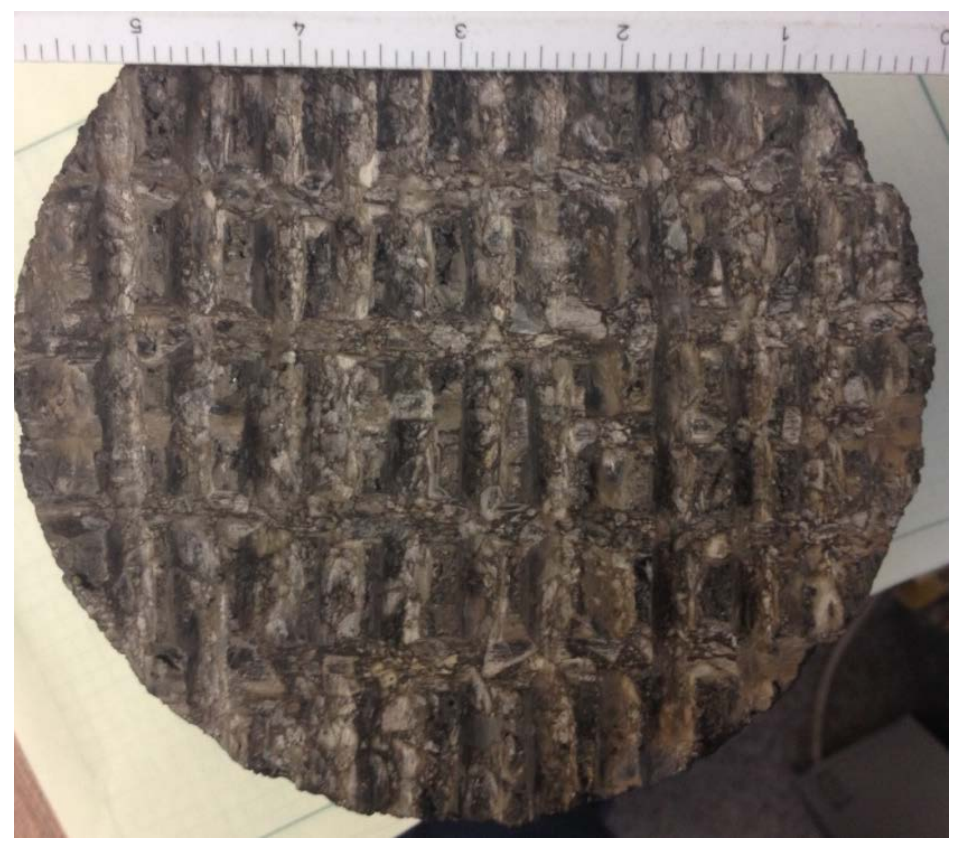

Figure 5: Laboratory Simulated Milling of a Superpave Sample 
Tests were performed on samples to determine the effect of compaction effort on the VTM of the top layer and the bond strength. Two samples were fabricated at compaction levels of 40, 60, and 80 gyrations. Volumetric analysis was performed on these samples. Using Equation 3, the approximate VTM for the top layer was determined. The samples were tested for bond strength, Table 4 . Samples compacted to 60 gyrations produced approximately $4 \%$ voids, and produced bond strengths similar to what was found in the literature.

$$
\mathrm{VTM}_{\mathrm{TOP}}=\frac{P_{\text {top }}}{\frac{100}{\mathrm{VTM}_{\text {Total }}}-\frac{P_{\text {bottom }}}{\mathrm{VTM}_{\text {Supporting }}}}
$$

Where,

Percent Top and Percent Supporting are percent of total mass

VTM Total - voids in the entire sample including top and supporting

VTM supporting - voids in the supporting layer of the sample

VTM Top - voids in the top portion of the sample

Table 4: Effect of Compaction Level on VTM of Top Layer and Bond Strength

\begin{tabular}{|c|c|c|c|}
\hline Sample & Gyrations & $\begin{array}{c}\text { VTM } \\
\text { Top }\end{array}$ & $\begin{array}{c}\text { Bond } \\
\text { Strength } \\
\text { (psi) }\end{array}$ \\
\hline 1 & 40 & 8.0 & 226 \\
\hline 2 & 40 & 7.6 & 226 \\
\hline 3 & 60 & 3.9 & 259 \\
\hline 4 & 60 & 3.7 & 263 \\
\hline 5 & 80 & 3.3 & 274 \\
\hline 6 & 80 & 3.4 & 270 \\
\hline
\end{tabular}

Tests were performed to determine the effect of rest period on the bond strength. These samples were fabricated using the cut face of the supporting layer. Two samples were fabricated with no tack, and two were fabricated with 3.6 grams of SS-1h emulsion. The emulsion was allowed to set for 2 hours prior to the compaction of the top layer. One of each sample was broken after 6 hours and the others were broken after 18 hours. Table 5 shows the effect of rest 
period on the bond strength, and a 24 hour rest period between fabrication and breaking was selected for this study.

These investigative tests were performed to determine the experimental bond strength procedure for use in this study. The supporting layers was compacted to 80 gyrations as full height samples and then cut in half. The cut face of the supporting layer was used as the interface. The overlay was placed in the SGC and compacted to 60 gyrations. The samples were allowed to rest for 22 hours at room temperature, and were placed in a waterproof bag for 2 hours at $77^{\circ} \mathrm{F}$, and were tested 24 hours after being fabricated. This material procedure is in Appendix 3.

Table 5: Effect of rest period on bond strength

\begin{tabular}{|c|c|c|c|c|}
\hline $\begin{array}{c}\text { Sample } \\
\text { ID }\end{array}$ & $\begin{array}{c}\text { Load } \\
\text { (lbs.) }\end{array}$ & $\begin{array}{c}\text { Bond } \\
\text { Strength } \\
(\mathrm{psi})\end{array}$ & Tack Coat & $\begin{array}{c}\text { Condition } \\
\text { Time }\end{array}$ \\
\hline 1 & 4600 & 168 & None & 6 hrs. \\
\hline 2 & 7000 & 256 & None & 18 hrs. \\
\hline 3 & 3800 & 139 & $\begin{array}{c}3.6 \text { grams } \\
\text { SS-1h }\end{array}$ & 6 hrs. \\
\hline 4 & 6600 & 241 & $\begin{array}{c}3.6 \text { grams } \\
\text { SS-1h }\end{array}$ & 18 hrs. \\
\hline
\end{tabular}

\subsection{EXPERIMENTAL DESIGN}

The experimental factors and levels, Table 6, contain mix designs and materials used in West Virginia. The mix designs for the support layer, provided by J.F. Allen, consisted of a $9.5 \mathrm{~mm}$ Superpave mix at 6 percent asphalt with a Theoretical Maximum Specific Gravity, $\mathrm{G}_{\mathrm{mm}}$ of 2.482 and a $19 \mathrm{~mm}$ Superpave mix at 4.9 percent asphalt with a $\mathrm{G}_{\mathrm{mm}}$ of 2.512. The same 9.5 $\mathrm{mm}$ mix was used for the top layer. The stockpile gradations, and percent in the blend for both mix designs are in Appendix 4. Figure 6 and Figure 7 display the gradation charts.

The aggregate was obtained from J.F. Allen and required sieving and washing in order to build the gradations for each mix. All of the aggregate was sieved, split into individual bins, and washed to remove any of the fine material. 
Table 6: Experimental Factors/Levels

\begin{tabular}{|c|c|c|c|c|c|}
\hline $\begin{array}{c}\text { Supporting } \\
\text { Layer }\end{array}$ & $\begin{array}{c}\text { Top } \\
\text { Layer } \\
\end{array}$ & $\begin{array}{c}\text { Surface } \\
\text { Condition } \\
\end{array}$ & $\begin{array}{c}\text { Tack Coat } \\
\text { Type } \\
\end{array}$ & $\begin{array}{c}\text { Setting } \\
\text { Time (hrs.) } \\
\end{array}$ & Replicates \\
\hline \multirow{8}{*}{$9.5-\mathrm{mm}$} & \multirow{8}{*}{$\begin{array}{l}9.5- \\
\mathrm{mm}\end{array}$} & \multirow{4}{*}{$\begin{array}{c}\text { Milled } \\
\text { (9.2 grams of } \\
\text { tack) }\end{array}$} & \multicolumn{2}{|c|}{ No Tack } & 6 \\
\hline & & & \multirow{2}{*}{ SS-1h } & 0.25 & 6 \\
\hline & & & & 2 & 6 \\
\hline & & & NTSS-1hm & 0.25 & 6 \\
\hline & & \multirow{4}{*}{$\begin{array}{l}\text { Cut Face } \\
\text { (3.6 grams of } \\
\text { tack) }\end{array}$} & \multicolumn{2}{|c|}{ No Tack } & 6 \\
\hline & & & \multirow{2}{*}{ SS-1h } & 0.25 & 6 \\
\hline & & & & 2 & 6 \\
\hline & & & NTSS-1hm & 0.25 & 6 \\
\hline $19-\mathrm{mm}$ & $\begin{array}{l}9.5- \\
\mathrm{mm}\end{array}$ & $\begin{array}{c}\text { Cut Face } \\
\text { (3.6 grams of } \\
\text { tack) }\end{array}$ & \multicolumn{2}{|c|}{ No Tack } & 6 \\
\hline \multicolumn{5}{|c|}{ Total Unconditioned samples - 54} & \\
\hline \multirow{6}{*}{$9.5-\mathrm{mm}$} & \multirow{6}{*}{$\begin{array}{l}9.5- \\
\mathrm{mm}\end{array}$} & \multirow{3}{*}{$\begin{array}{c}\text { Milled } \\
\text { (9.2 grams of } \\
\text { tack) }\end{array}$} & None & 0 & 2 \\
\hline & & & SS-1h & 0.25 & 2 \\
\hline & & & NTSS-1hm & 0.25 & 2 \\
\hline & & \multirow{3}{*}{$\begin{array}{l}\text { Cut Face (3.6 } \\
\text { grams of tack) }\end{array}$} & None & 0 & 2 \\
\hline & & & SS-1h & 0.25 & 2 \\
\hline & & & NTSS-1hm & 0.25 & 2 \\
\hline
\end{tabular}




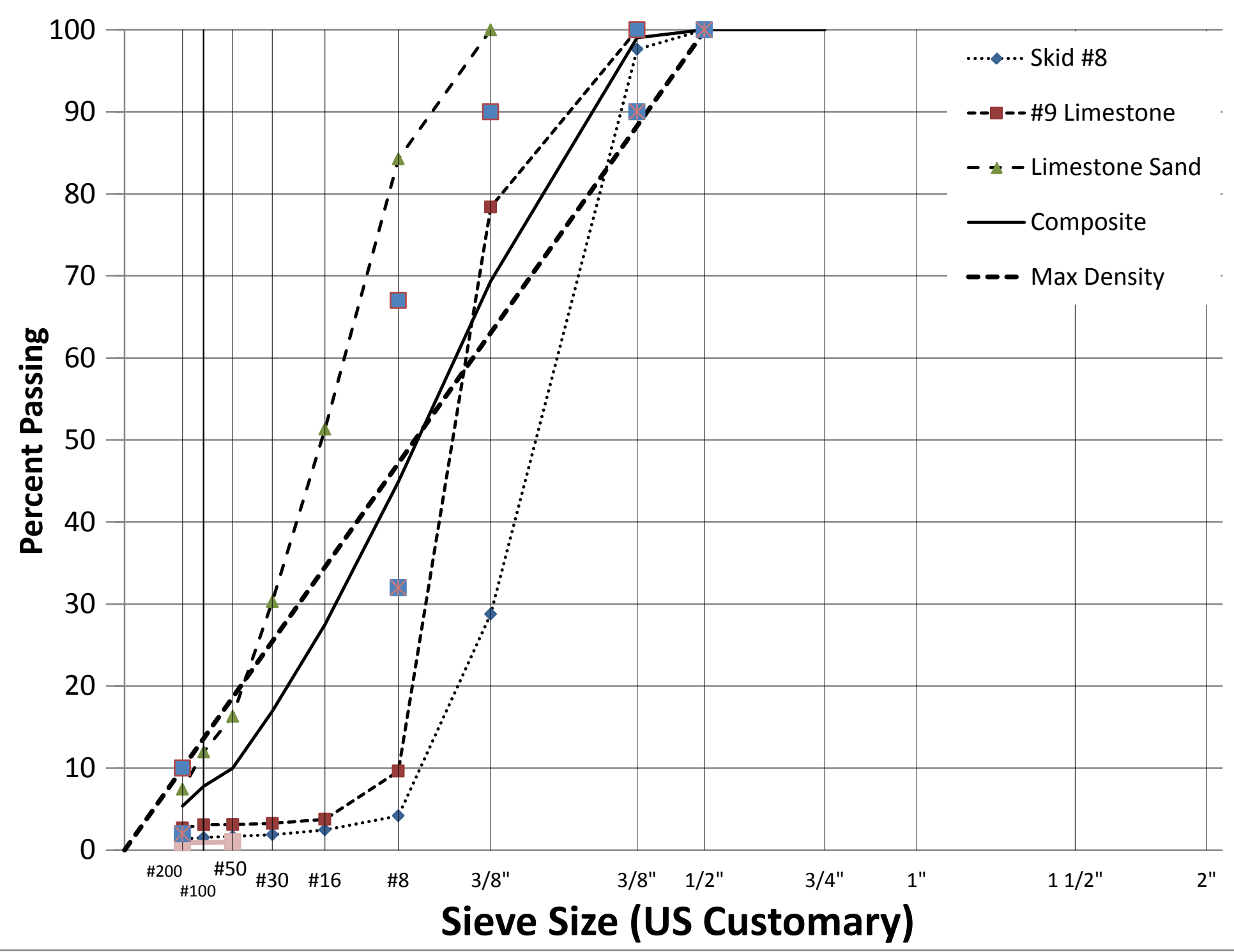

Figure 6: 9.5 mm Power 45 Gradation Design Blend 


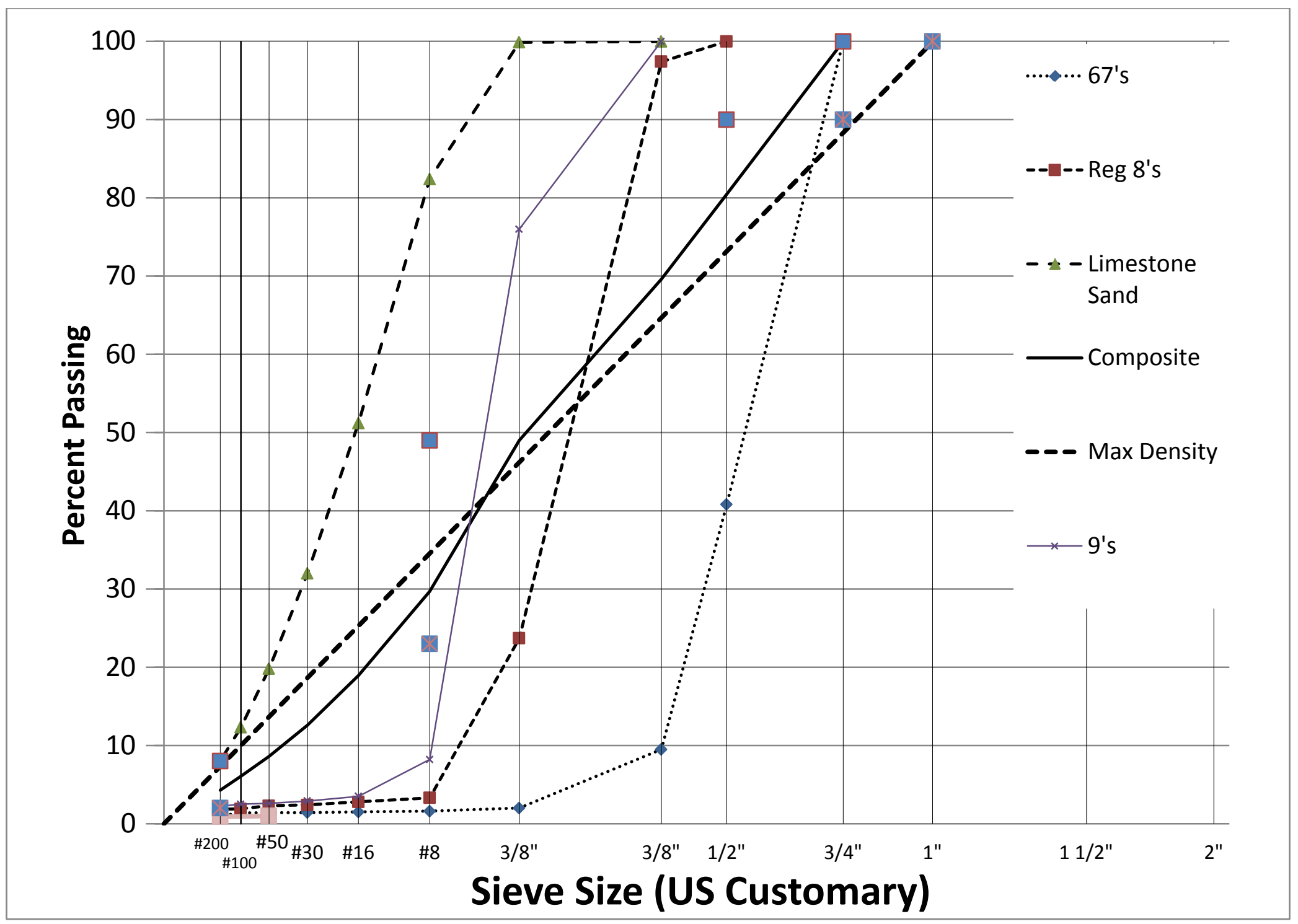

Figure 7: 19 mm Power 45 Gradation Design Blend 


\subsection{BOND STRENGTH TESTING}

Three supporting layer interface conditions were studied. The $9.5 \mathrm{~mm}$ mix supporting layer face was either a cut or was milled. The $19 \mathrm{~mm}$ mix supporting layer was cut face only. This is because a $19 \mathrm{~mm}$ mix is placed as a base layer and is typically not milled prior to an overlay. The supporting layer interface was either non-tacked, or tacked with either SS-1h or NTSS-1hm emulsion. The cut surface was tacked with 3.6 grams of tack and the milled surface was tacked with 9.2 grams of tack. The tack was spread evenly on the entire supporting layer surface with a paint brush. To evaluate the effects of emulsion set time, set times of 0.25 and 2 hours were selected for the SS-1h, and only 0.25 hours was selected for the NTSS- $1 \mathrm{hm}$ since the inherent nature of this tack is to set quickly, The Blacklidge Emulsion website has more details about this trackless tack (Blacklidge Emulsions , 2013). The effect of conditioning was also evaluated in this study with the use of the AASHTO T283 Standard Test Method for Determination of the Resistance of Compacted Bituminous Mixture to Moisture Induced Damage. This was performed to simulate what would happen if water were to infiltrate between the overlay and the existing pavement and it were to freeze. This data is in Appendix 7.

The fabrication matrix was randomized to minimize potential bias of the results. This was performed by listing all of the factors and levels in a column, and assigning a random number to each replicate using the random number generator in Excel. Next the list was sorted by the random number and the samples were made in the random numerical order.

The bulk specific gravities of all the supporting layers were determined. The average macrotexture for the milled samples used in this study was $1.3 \mathrm{~mm}$ with a standard deviation of $0.08 \mathrm{~mm}$, Appendix 5. An angle grinder was used on the sides of the supporting layers to ensure they fit back into the Superpave mold with ease, since the samples swell a small amount when they are removed from the molds. All supporting layers were washed and vacuum dried prior to application of the top layer. Tack coat, SS-1h, NTSS-1hm, or no tack was applied, at the rates specified in the experimental design, to the interface of the supporting layer and allowed to set

for either 0.25 or 2 hours. The supporting layer of the sample was placed in the SGC mold, and then the virgin mix was placed and compacted to 60 gyrations. The bulk specific gravity of the entire sample was determined, and Equation 3 was used to estimate the voids in the top layer of 
each sample. Each sample was then tested in accordance with the testing procedure 24 hours from the time it was fabricated. Figure 8 is an example of a fabricated sample.

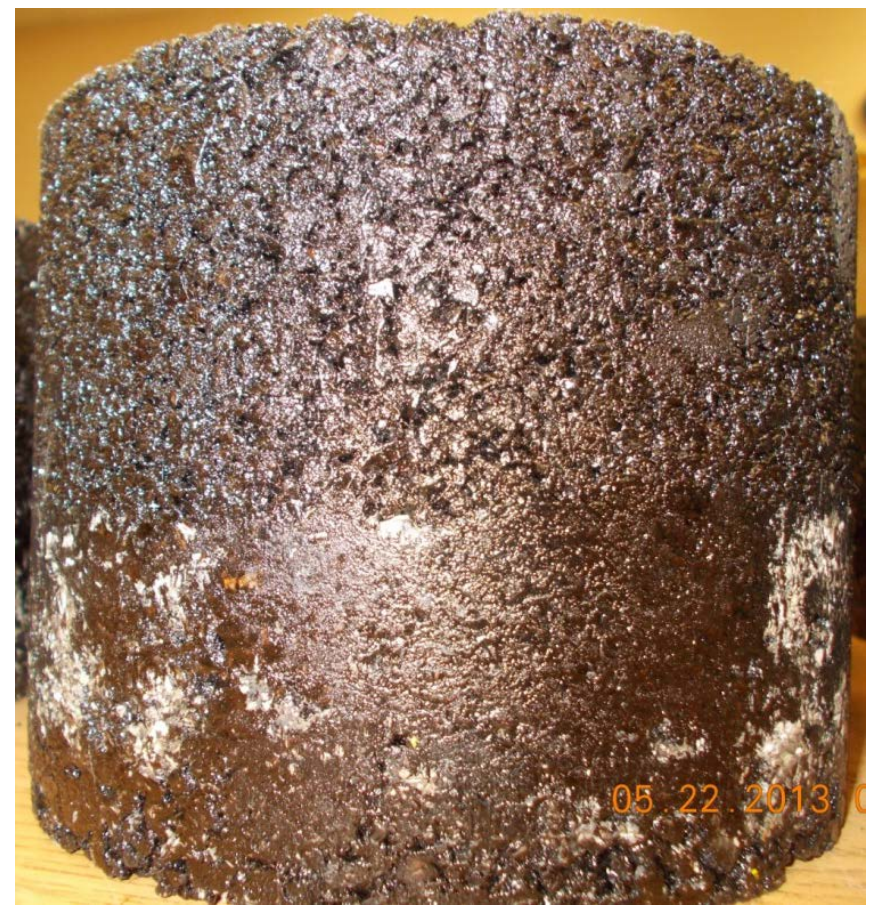

Figure 8: Composite Sample

The test results were evaluated using the Student's t-test. The Student's t-test is a statistical hypothesis test investigating two population means, and is used when the variances of two normal distributions are unknown. The null hypothesis was the average bond strengths for the two populations being analyzed were equal. The alternative hypothesis was the average bond strengths for the two populations being analyzed were different. The null hypothesis was rejected if the $\mathrm{p}$-value is less than 0.05 , and a p-value greater than or equal to 0.05 indicates insufficient information to reject the null hypothesis.

\subsection{FIELD EVALUATION}

Field cores were extracted from a paving job and sent to the National Center for Asphalt Technology (NCAT) for bond strength testing. This paving job evaluated two tack coats, Ultrafuse and CSS-1H. The Ultrafuse was subjected to application rates of $0.08,0.13$, and $0.15 \mathrm{gal} / \mathrm{yd} 2$. The overlay portion of these cores was a Marshall Wearing I mix. 
Six cores were extracted from I-64 in West Virginia. The overlay mix was a $12.5 \mathrm{~mm}$ Superpave mix. These cores were tested in the Materials and Research Lab in Charleston West Virginia. Three cores were tested after two hours of conditioning in a water bath at $77^{\circ} \mathrm{F}$, two cores were tested at room temperature at $71^{\circ} \mathrm{F}$, and one core was frozen prior to being tested. 


\section{CHAPTER 4 RESULTS AND ANALYSIS}

\subsection{INTRODUCTION}

A total of 66 samples were tested for bond strength. The factors and levels of the experiment are shown in Table 6. For non-conditioned samples, 6 samples were made for each level; while for conditioned samples only 2 samples were made for each level, resulting in 66 tests.

\subsection{EXPERIMENTAL BOND STRENGTH RESULTS}

The data presented in Table 7 shows the mean, standard deviations of the bond strengths as well as the supporting and top layer VTM. The raw data used for the following analysis is presented in Appendix 6.

Table 7: Bond Strength Test Results

\begin{tabular}{|c|c|c|c|c|c|c|c|c|}
\hline & $\begin{array}{c}\text { Support } \\
\text { ing } \\
\text { NMAS }\end{array}$ & $\begin{array}{c}\text { Surface } \\
\text { Condition }\end{array}$ & $\begin{array}{l}\text { Tack Coat } \\
\text { Type }\end{array}$ & $\begin{array}{l}\text { Setting Time } \\
\text { (hrs.) }\end{array}$ & $\begin{array}{l}\text { Average } \\
\text { Bond } \\
\text { Strength } \\
\text { (psi) }\end{array}$ & $\begin{array}{l}\text { Standard } \\
\text { Deviation }\end{array}$ & $\begin{array}{c}\text { Average } \\
\text { Supporting } \\
\text { VTM }\end{array}$ & $\begin{array}{c}\text { Average } \\
\text { Top } \\
\text { VTM }\end{array}$ \\
\hline \multirow{9}{*}{ 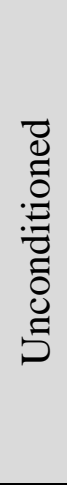 } & 9.5 & Milled & SS-1h & 0.25 & 165 & 14 & 6.0 & 5.6 \\
\hline & 9.5 & Milled & SS-1h & 2 & 197 & 29 & 5.1 & 5.4 \\
\hline & 9.5 & Milled & None & 0 & 210 & 21 & 5.1 & 5.1 \\
\hline & 9.5 & Milled & NTSS-1hm & 0.25 & 196 & 10 & 5.3 & 6.2 \\
\hline & 9.5 & Cut & SS-1h & 0.25 & 189 & 16 & 5.4 & 5.7 \\
\hline & 9.5 & Cut & SS-1h & 2 & 211 & 13 & 5.0 & 5.4 \\
\hline & 9.5 & Cut & None & 0 & 201 & 19 & 5.2 & 5.7 \\
\hline & 9.5 & Cut & NTSS-1hm & 0.25 & 222 & 34 & 4.2 & 4.7 \\
\hline & 19 & Cut & None & 0 & 212 & 34 & 6.0 & 6.1 \\
\hline \multirow{6}{*}{ 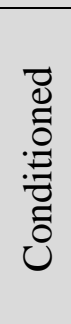 } & 9.5 & Cut & None & 0 & 161 & 5 & 7.3 & 5.7 \\
\hline & 9.5 & Cut & NTSS-1hm & 0.25 & 153 & 5 & 5.4 & 6.8 \\
\hline & 9.5 & Cut & SS-1h & 0.25 & 124 & 5 & 5.7 & 8.8 \\
\hline & 9.5 & Milled & None & 0 & 166 & 3 & 5.5 & 6.0 \\
\hline & 9.5 & Milled & NTSS-1hm & 0.25 & 175 & 15 & 6.7 & 5.5 \\
\hline & 9.5 & Milled & SS-1h & 0.25 & 151 & 8 & 4.1 & 10.9 \\
\hline
\end{tabular}




\subsection{INFLUENCE OF SUPPORTING LAYER NMAS ON BOND STRENGTH}

The following results relate to cut faced supporting layers fabricated without tack coat. The average bond strength for a $9.5 \mathrm{~mm}$ mix placed over a $19 \mathrm{~mm}$ mix was $212 \mathrm{psi}$ with a standard deviation of $34 \mathrm{psi}$. The average bond strength for $9.5 \mathrm{~mm}$ mix placed over a $9.5 \mathrm{~mm}$ mix was 201 psi with a standard deviation of 19 psi. As shown in Figure 9, over 6 trials the 19 mm supporting layer exhibited higher bond strengths, on average, than the $9.5 \mathrm{~mm}$ supporting layer. The Student's t test was performed using the null hypothesis that the bond strength for the two base types was equal and the alternative hypothesis was the strengths were not equal. A 95 percent confidence level, $\mathrm{p}$-value of 0.05 was used. The computed p-value was 0.51 indicating insufficient data to reject the null hypothesis; implying the NMAS of the support layer does not increase bond strength.

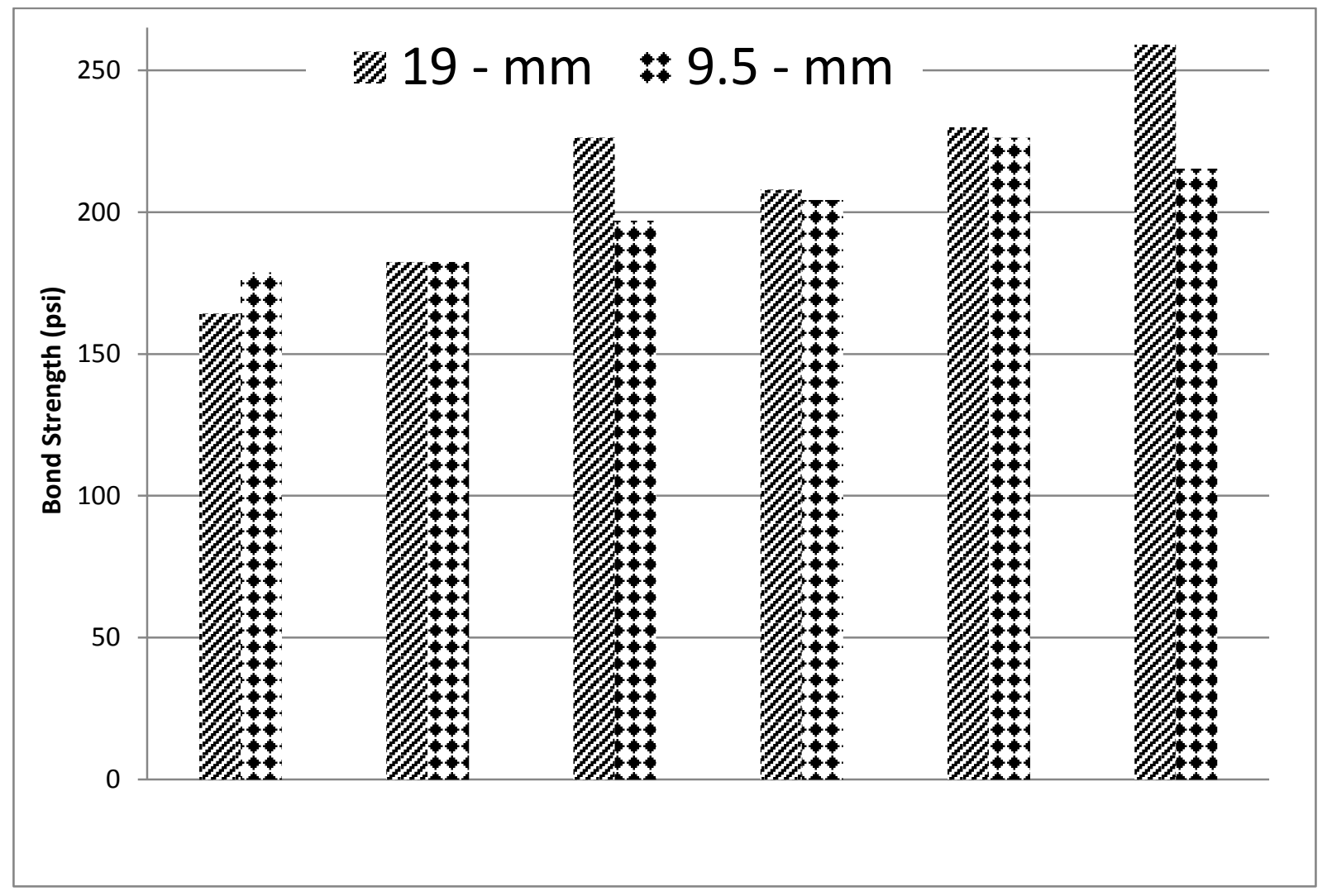

Figure 9: $19 \mathrm{~mm}$ and $9.5 \mathrm{~mm}$ Supporting Layer Bond Strengths. 


\subsection{INFLUENCE OF INTERFACE CONDITION}

The average bond strengths for the cut face and milled face samples can be found in Table 7 and in Figure 10. The Student's t test was performed using the null hypothesis that the bond strength for the two interface conditions was equal and the alternative hypothesis was the strengths were not equal. A 95 percent confidence level, p-value of 0.05 was used. The computed p-value was 0.17 indicating insufficient data to reject the null hypothesis; implying the milling the support layer does not increase bond strength.

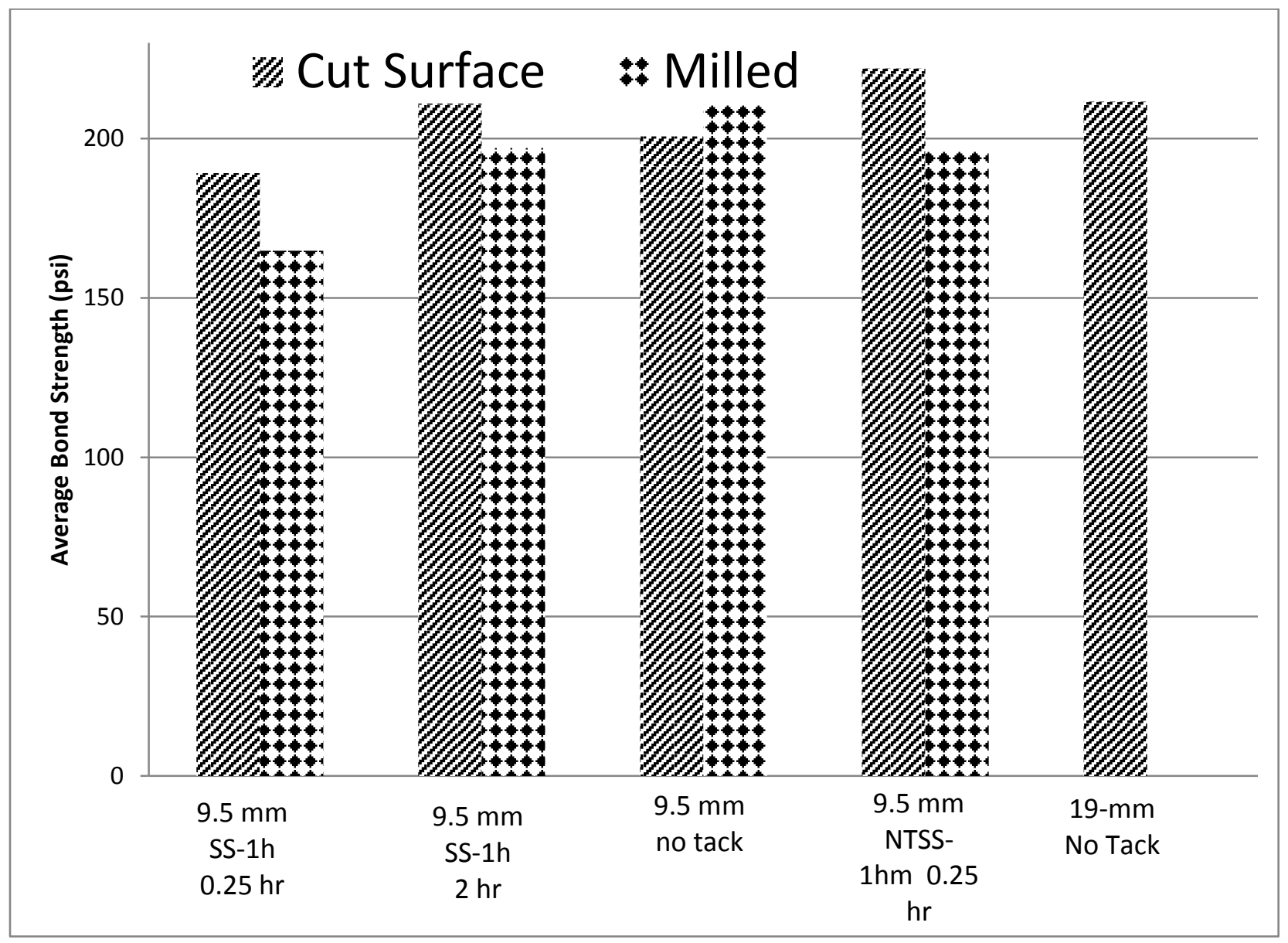

Figure 10: Cut Surface versus Milled Surface Bond Strengths

This observation contradicts findings by Tashman et al. (2006) and Tran et al. (2012). Several things were inspected in lieu of this finding. First, the interfaces of the cut and milled interfaces were inspected for excess voids, aggregate interlock, etc. Figure 11 shows a picture of a cut and milled interface fabricated without tack coat, after testing. 


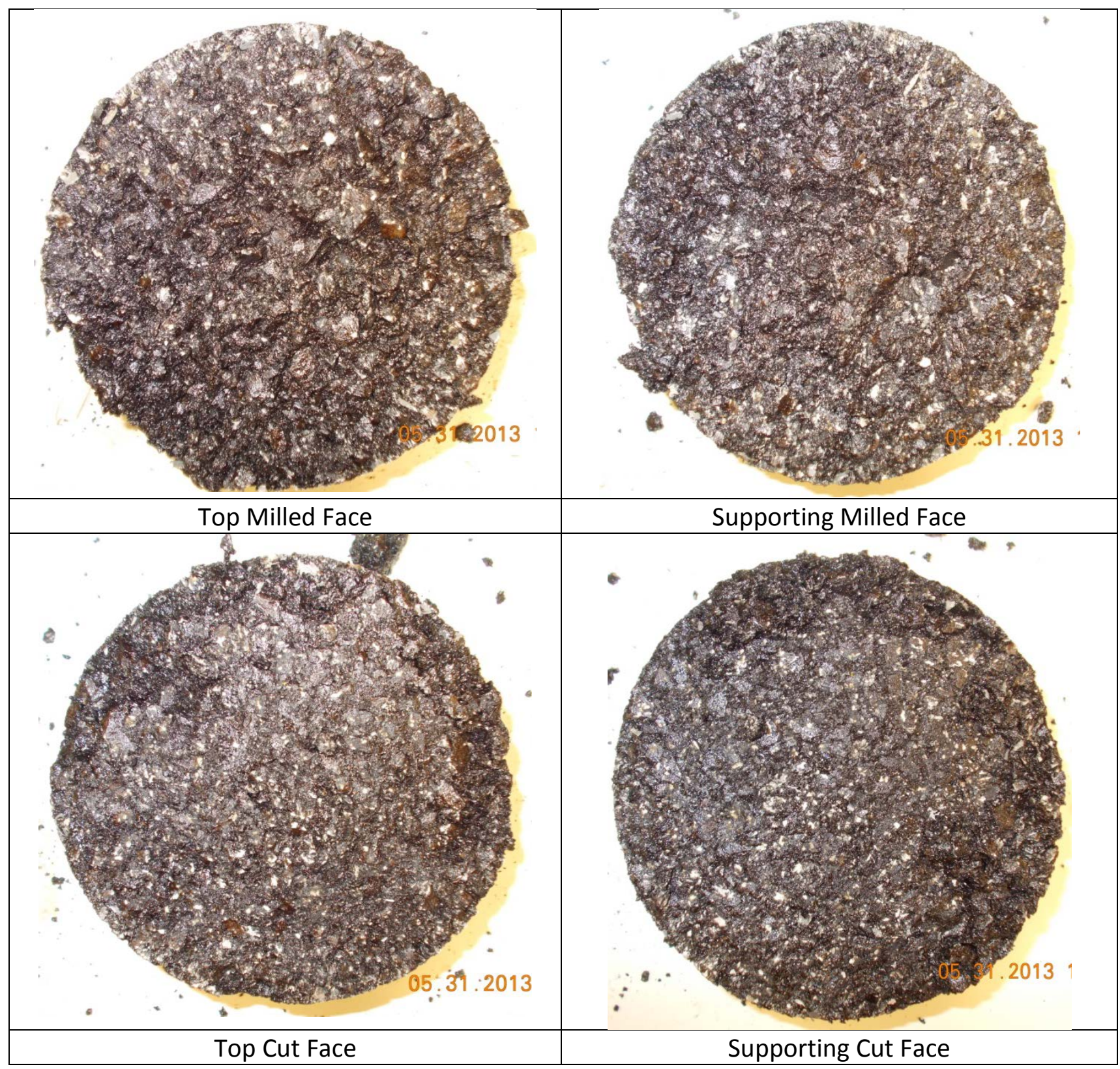

Figure 11: Milled and Cut Broken Interfaces

The milled interface seems to have more voids, while the cut face is clean and compact. One cut and one milled face top layer was then cut in half to inspect the aggregate distribution along the interface, providing a cross section view, Figure 12. This figure shows no apparent difference between the aggregate distribution on the cut face and milled face. The only difference was the voids, indentations, and unevenness of the milled surface interface in Figure 11. This can lead to a reduction in the contact interface and therefore result in lower shear forces as described by Raab and Partl (2004). 


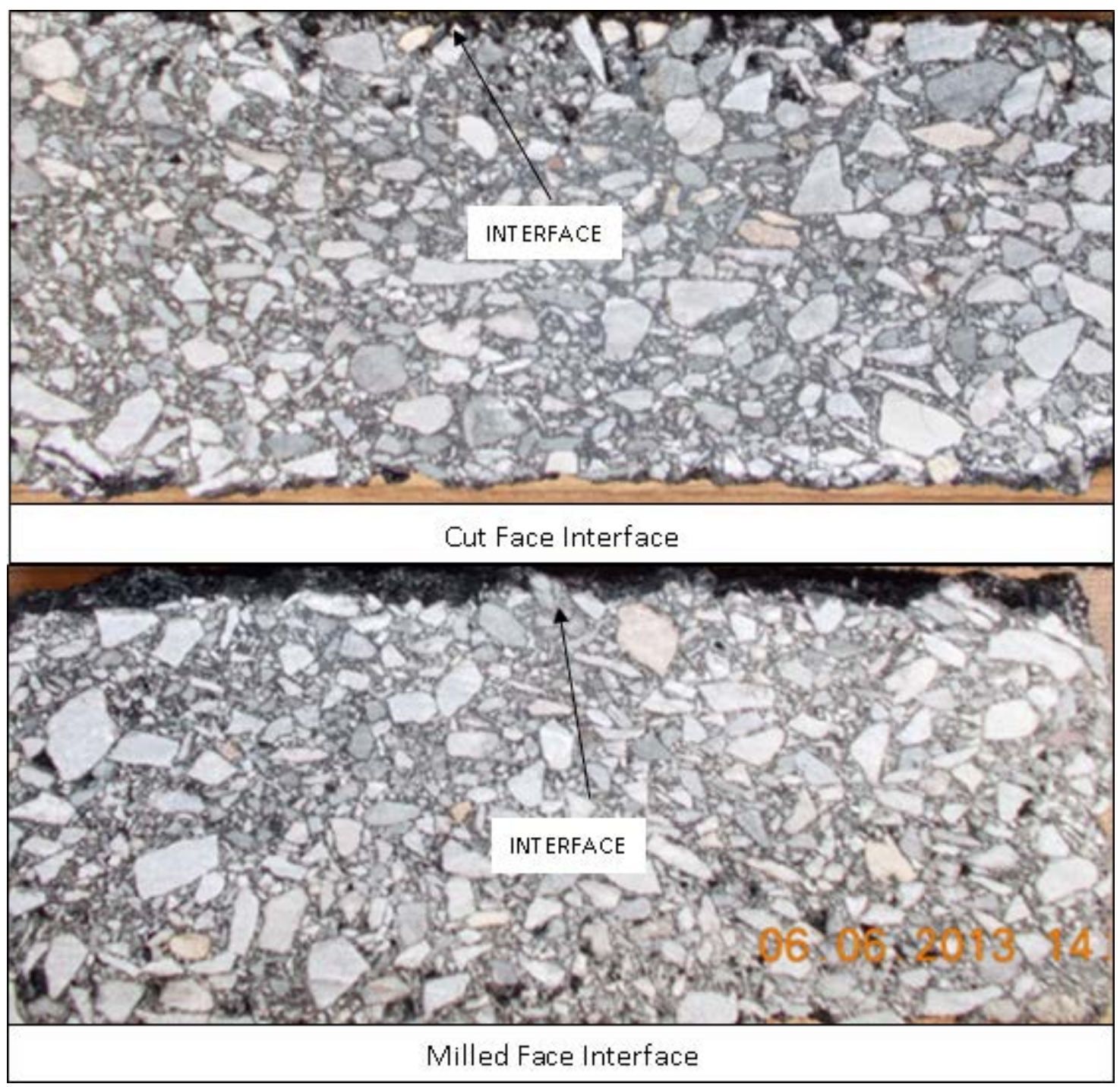

Figure 12: Interface Aggregate Distribution

Another observation about the nature of cut or milled face samples was the fracture mechanism. The cut faced samples reached peak strength and had no measurable residual strength. The milled face samples reached peak strength and slowly became asymptotic to some residual strength, Figure 13. 

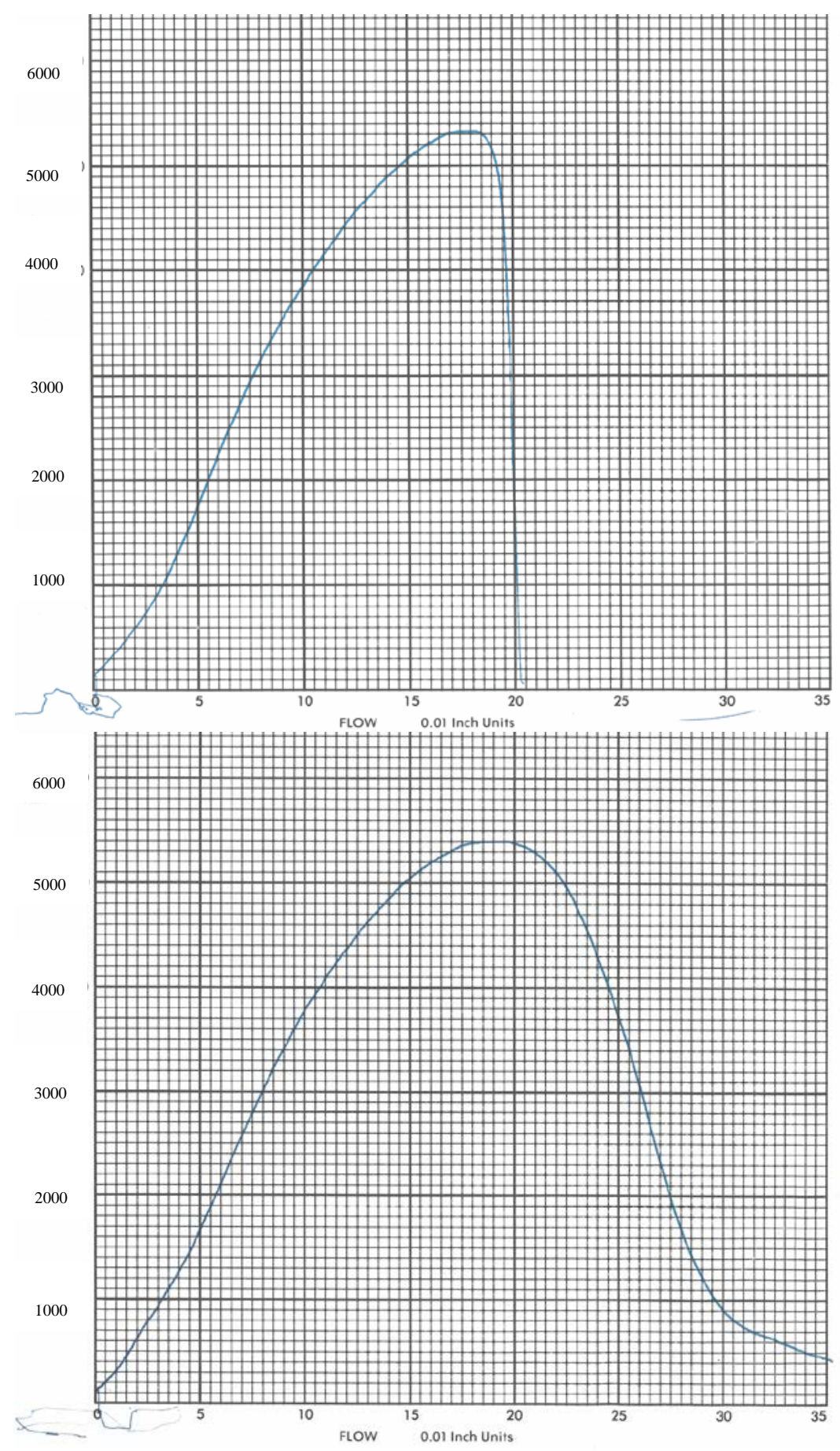

Figure 13: Top) cut surface. Bottom) milled Surface. 


\subsection{INFLUENCE OF TACK COAT}

For milled supporting layers, the average bond strength for non-tacked samples was 210 psi with a standard deviation of 21 psi. The non-tacked samples, on average, showed higher bond strengths than all of the tacked milled surfaces. This data can be found in Table 7 and in Figure 14. For cut faced supporting layers, the non-tacked interface had average bond strengths of 212 psi with a standard deviation of 34 psi. The NTSS-1hm sample showed the highest bond strengths on average, as seen in Table 7 and in Figure 15.

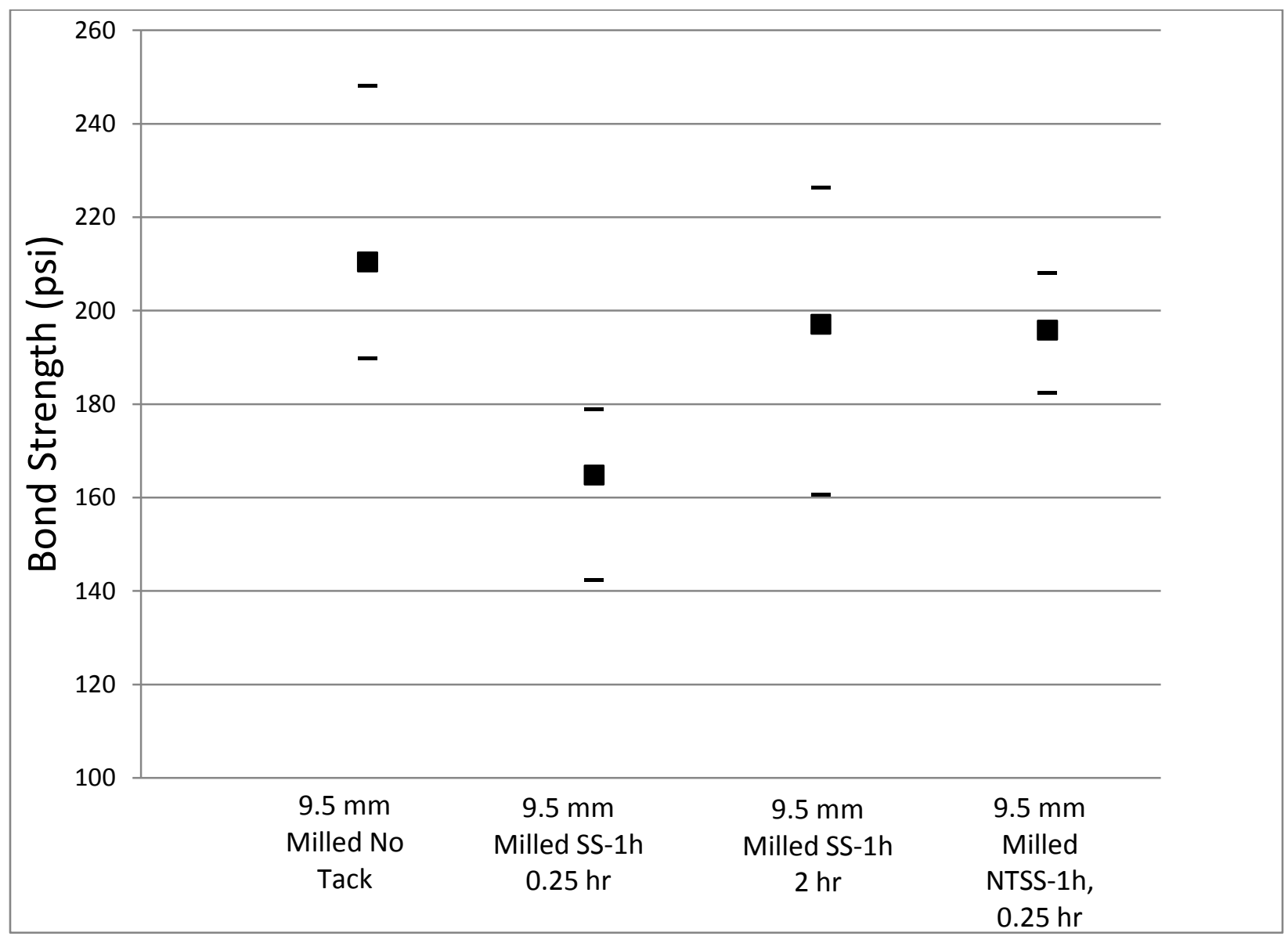

Figure 14: Milled Test Results

*Note 9.5, Milled, SS-1h, .25 hrs. Indicates 9.5mm milled supporting layer with SS-1h tack coat allowed to set for 0.25 hours. 


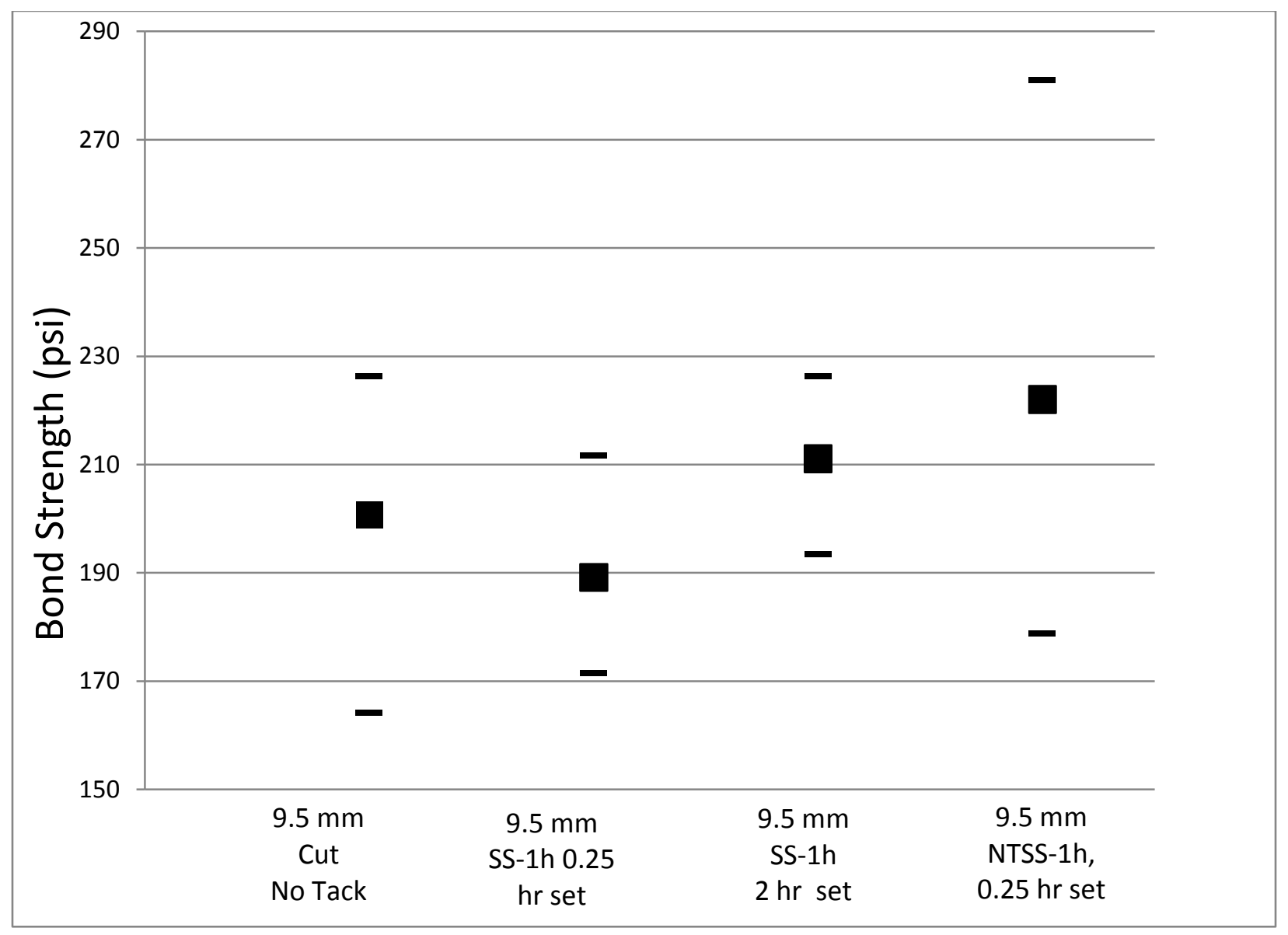

Figure 15: Cut Faced Sample Results

The P-values from the Student's t-tests are summarized in Table 8. In each case the null hypothesis was the bond strength of the non-tacked surface was equal to the tacked surface and the alternative hypothesis was the bond strengths were not equal. A 95 percent confidence level, p-value of 0.05 was used. The only Student's t-test that showed a statistical difference was the milled samples with SS-1h and a 0.25 hour setting time. In all other cases there was insufficient information to reject the null hypothesis, indicating tack coat did not increase the bond strength compared to the non-tacked surfaces. 
Table 8: Statistical Analysis of Tacked Versus Non Tacked Samples

\begin{tabular}{|l|c|}
\hline \multicolumn{1}{|c|}{ Characteristics } & p value \\
\hline 9.5, Milled, SS-1h, 0.25 hrs. & $\mathbf{0 . 0 0 1}$ \\
\hline 9.5, Milled, SS-1h, 2 hrs. & 0.376 \\
\hline 9.5, Milled, NTSS-1hm, 0.25 hrs. & 0.155 \\
\hline 9.5, Cut Face SS-1h, .25 hrs. & 0.274 \\
\hline 9.5, Cut Face, SS-1h, 2 hrs. & 0.292 \\
\hline 9.5, Cut Face NTSS-1hm, 0.25 hrs. & 0.203 \\
\hline
\end{tabular}

* Bold indicates statistical significance at 95\% confidence level.

\subsection{INFLUENCE OF TACK COAT TYPE ON BOND STRENGTH}

Two tack coat types were evaluated, NTSS-1hm and SS-1h allowed to set for 0.25 hours. For the cut supporting layers the NTSS-1hm average bond strength was 222 psi with a standard deviation of 34 psi, while the SS-1h average bond strength was 189 psi with a standard deviation of 16 psi. For the milled supporting layers the NTSS-1hm averaged bond strength was196 psi with a standard deviation of 10 while the SS-1h averaged bond strength was 165 psi with a standard deviation of 14, in Figure 16

Comparing the NTSS-1hm allowed to set for 0.25 hours and the SS-1h allowed to set for 2 hours, the cut surfaces resulted in average bond strength of 222 psi with a standard deviation of 34 psi and the SS-1h had an average bond strength of 211 psi with a standard deviation of 13 psi. For milled surfaces the average bond strength was 196 psi with a standard deviation of 10 psi and average bond strengths of 197 psi with a standard deviation of 29 psi, respectively, Shown in Figure 16.

In each case the null hypothesis was the bond strength using different tack coats was equal and the alternative hypothesis was the bond strengths were not equal. The Student's t-tests showed a statistical difference for the milled supporting layer at a $0.25 \mathrm{hr}$. set time with a p-value $<0.001$. In all other cases there was insufficient information to reject the null hypothesis, indicating tack coat type did not influence the bond strength for those cases. 


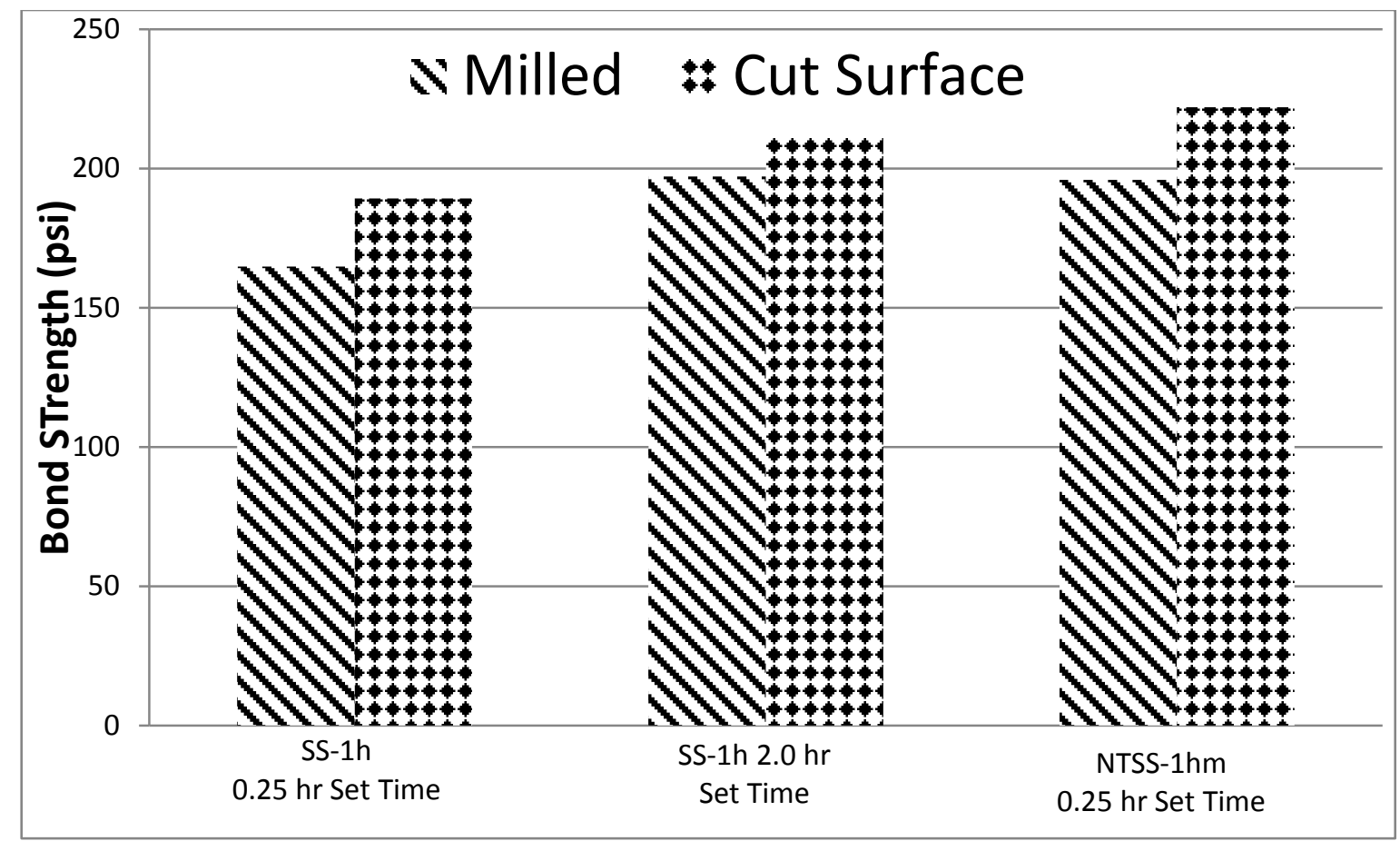

Figure 16: Difference in Tack Coat Type

\subsection{INFLUENCE OF TACK COAT SET TIME ON BOND STRENGTH}

The SS-1h tack coat was subjected to two set times, 0.25 and 2 hours. Figure 17 shows the average and range of each test. For the milled surface, a 0.25 hour set time had average bond strengths of 165 psi with a standard deviation of 14 psi, while a 2 hour set time showed bond strengths of 197 psi with a standard deviation of 29 psi. For a cut surface, a 0.25 hour set time had average bond strength of 189 psi with a standard deviation of 16 psi; while the 2 hour set time had average bond strength of 211 psi with a standard deviation of 13 psi. The Student's t test was performed using the null hypothesis that the bond strength for the two tack coats was equal and the alternative hypothesis was the strengths were not equal. A 95 percent confidence level, p-value of 0.05 was used. The computed p-value indicates significant differences for cut and milled surfaces with p-values of 0.028 and 0.032 respectively. 


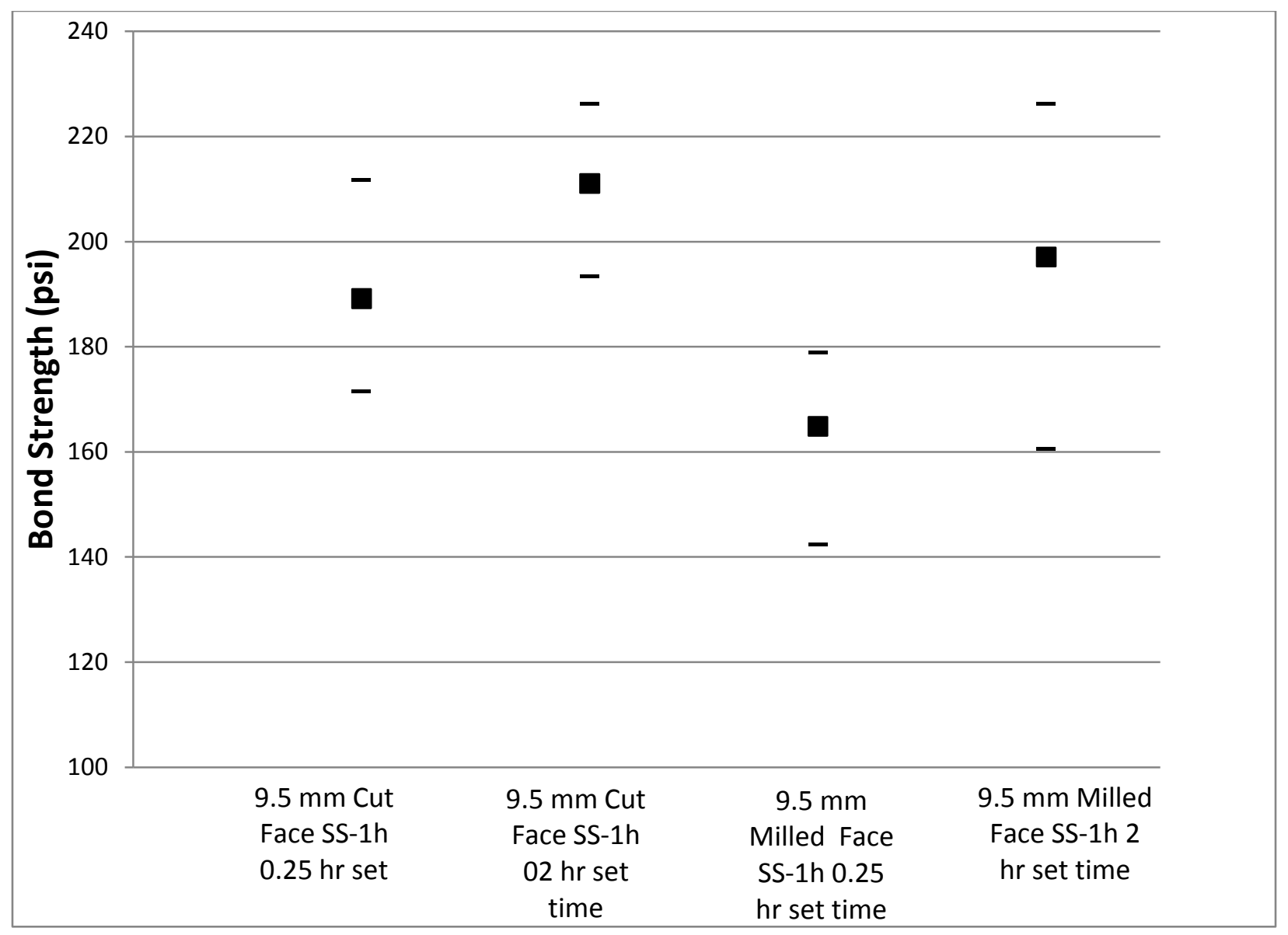

Figure 17: Difference in Bond Strength by Varying Setting Time

\subsection{CONDITIONED VERSUS NON CONDITIONED SAMPLES}

The non-conditioned samples were fabricated and tested 24 hours later for bond strength. The conditioned samples underwent the AASHTO T283, and were tested 72 hours after being fabricated. The average bond strengths for the conditioned samples are presented in Table 9. 
Table 9: Conditioned versus Non Conditioned Results

\begin{tabular}{|c|c|c|c|c|c|c|c|c|}
\hline $\begin{array}{c}\text { Suppor } \\
\text { ting } \\
\text { NMAS }\end{array}$ & $\begin{array}{c}\text { Surface } \\
\text { Conditio } \\
\text { n }\end{array}$ & $\begin{array}{c}\text { Tack Coat } \\
\text { Type }\end{array}$ & $\begin{array}{c}\text { Curing } \\
\text { Time }\end{array}$ & $\begin{array}{c}\text { Non } \\
\text { Conditioned }\end{array}$ & Conditioned & Difference & $\begin{array}{c}\text { Percent } \\
\text { Decrease }\end{array}$ & P value \\
\hline 9.5 & Cut & None & 0 & 201 & 161 & 40 & $20 \%$ & $\mathbf{0 . 0 2 7 5}$ \\
\hline 9.5 & Cut & NTSS-1hm & 0.25 & 222 & 153 & 69 & $31 \%$ & $\mathbf{0 . 0 3 3 4}$ \\
\hline 9.5 & Cut & SS-1h & 0.25 & 189 & 124 & 65 & $34 \%$ & $\mathbf{0 . 0 0 1 7}$ \\
\hline 9.5 & Milled & None & 0 & 210 & 166 & 44 & $21 \%$ & $\mathbf{0 . 0 2 9 8}$ \\
\hline 9.5 & Milled & NTSS-1hm & 0.25 & 196 & 175 & 21 & $11 \%$ & 0.0623 \\
\hline 9.5 & Milled & SS-1h & 0.25 & 165 & 151 & 13 & $8 \%$ & 0.252 \\
\hline
\end{tabular}

*Bold Indicates statistical difference at the $95 \%$ confidence level.

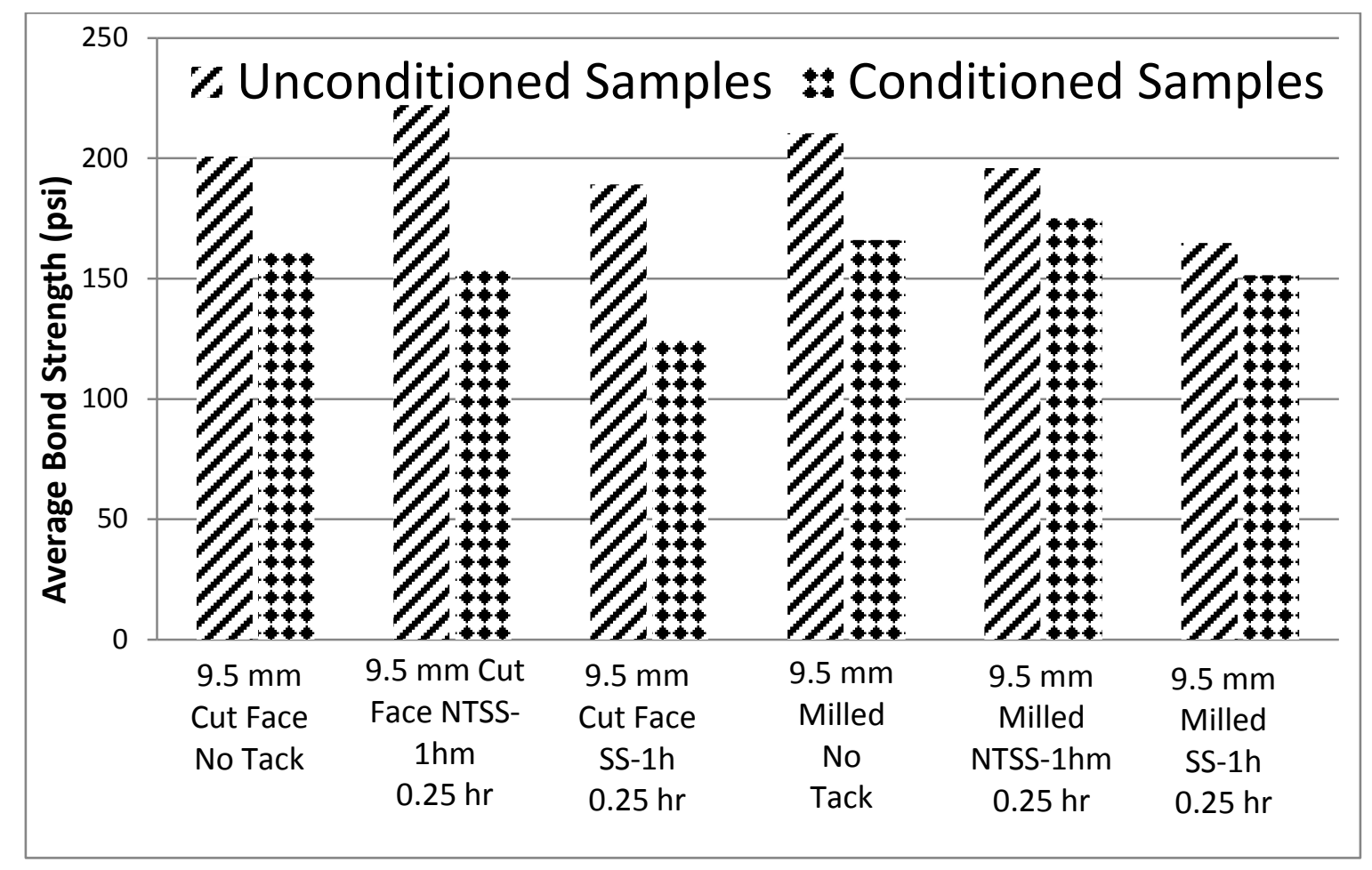

Figure 18: Influence of Conditioning on Bond Strength

As presented in Figure 18, the conditioning had a more profound effect on the cut faced samples, similar to the results presented by Al-Qadi et al., (2008) and Taylor et al (2012). All samples show a decrease in bond strength, between $8 \%$ and $34 \%$. The tacked cut surfaces exhibited the most decrease in strength for the cut supporting layers. The non-tacked milled surface showed the largest decrease in strength for milled supporting layers. The Student's t test was performed using the null hypothesis that the bond strength for conditioned and non- 
conditioned was equal and the alternative hypothesis was the strengths were not equal. A 95 percent confidence level, p-value of 0.05 was used. The computed p-value indicates significant differences for:

- Cut Faced samples with no tack

- Cut faced samples with NTSS-1hm and set time of 0.25 hrs

- Cut faced samples with SS-1h and set time of 0.25 hrs

- Milled face with no tack.

The null hypothesis could not be rejected for Milled samples with NTSS-1hm and SS-1h at 0.25 hour set times.

Comparing the conditioned samples to the non-conditioned samples as a whole resulted in a p value approaching zero, displaying a large statistical difference between conditioned and non-conditioned samples.

\subsection{COMPARISON TO PUBLISHED RESULTS}

Several authors presented minimum acceptable bond strengths. Mohammad et al. (2011) suggested that 40 psi is acceptable bond strength to facilitate ample strength in field conditions. Tran et al. (2012) suggested that in accordance with Alabama DOT Procedure 430, 100 psi should be the minimum acceptable bond strength for asphalt overlays. The strengths determined via the laboratory program above all surpassed the recommended minimum bond strengths in the literature.

Another factor, described by Al-Qadi et al. (2012 a), can be the fact the SGC molds were heated to $153^{\circ} \mathrm{C}$ prior to placing the supporting half of the sample in. Though this procedure was done as fast as possible, the heat from the mold could have increased the bond strength of the sample.

A study performed by Tran et al. (2012) used a $25 \mathrm{~mm}$ base with a $12.5 \mathrm{~mm}$ overlay. A NTSS-1hm tack coat was used on a milled and a new surface, at application rates of 0.0, 0.04, 0.06 , and $0.08 \mathrm{gal} / \mathrm{yd}^{2}$. The author concluded that the bond strength of the new surfaces ranged from 153 psi to 255 psi, while milled surface had bond strengths of 167 to 243 psi. At an application rate of 0.04 gallons per square yard, Tran reported bond strengths of 205 psi for a 
new surface, while this study resulted in bond strengths of $222 \mathrm{psi}$. Also, at an application rate of $0.08 \mathrm{gal} / \mathrm{yd}^{2}$ on a milled surface, Tran reported bond strengths of $198 \mathrm{psi}$, while this study resulted in bond strength of $196 \mathrm{psi}$ for a 0.115 gallon per square yard application rate. However these results were for field cores and may not be comparable to laboratory testing.

\subsection{FIELD BOND STRENGTH RESULTS.}

The bond strengths of the cores extracted from the field pavements (WHERE) are shown in Table 10.

On average the Ultrafuse tack coat at an application rate of $0.08 \mathrm{gal} / \mathrm{yd}^{2}$ exhibited the highest average bond strength. The CSS-1H showed the lowest bond strengths. The Student's t test was performed using the null hypothesis that the bond strength for samples were equal and the alternative hypothesis was the strengths were not equal. The only Student's t-test that showed a statistical difference between the Ultrafuse applied at $0.18 \mathrm{gal} / \mathrm{yd}^{2}$ and the CSS-1H tack coated samples. The null hypothesis could not be rejected for the other samples, as noted in Table 11

The cores extracted from I-64 in Dunbar West Virginia showed bond strengths in Table 12. The average bond strengths for cores tested at $77^{\circ} \mathrm{F}$ was $137 \mathrm{psi}$, cores tested at $71^{\circ} \mathrm{F}$ exhibited bond strengths of $196 \mathrm{psi}$. The core that was tested after being frozen maxed out the 10,000 lb. load frame. This displays that conditioning temperature in has an effect on the bond strength of pavements. All cores also surpassed the recommended minimum bond strength presented by West et al, (2005). 
Table 10: Field Testing Results

\begin{tabular}{|c|c|c|c|c|}
\hline Core & $\begin{array}{l}\text { Tack } \\
\text { Coat } \\
\text { Type }\end{array}$ & $\begin{array}{l}\text { Application } \\
\text { Rate }\end{array}$ & $\begin{array}{c}\text { Failure } \\
\text { Load } \\
\text { (lbf) }\end{array}$ & $\begin{array}{l}\text { Bond } \\
\text { Strength } \\
\text { (psi) }\end{array}$ \\
\hline 1 & \multirow{3}{*}{ Ultrafuse } & \multirow{3}{*}{0.18} & 4400 & 161 \\
\hline 2 & & & 4100 & 153 \\
\hline 3 & & & 3900 & 142 \\
\hline Average & & & 4133 & 152 \\
\hline Standard Deviation & & & 252 & 9.7 \\
\hline 4 & \multirow{3}{*}{ Ultrafuse } & \multirow{3}{*}{0.13} & 3800 & 139 \\
\hline 5 & & & 4900 & 180 \\
\hline 6 & & & 3400 & 126 \\
\hline Average & & & 4033 & 149 \\
\hline Standard Deviation & & & 777 & 28.2 \\
\hline 7 & \multirow{3}{*}{ Ultrafuse } & \multirow{3}{*}{0.08} & 3750 & 137 \\
\hline 8 & & & 4300 & 157 \\
\hline 9 & & & 5000 & 183 \\
\hline Average & & & 4350 & 159 \\
\hline Standard Deviation & & & 626 & 23.1 \\
\hline $\mathrm{B}$ & \multirow{2}{*}{ CSS-1H } & & 3100 & 136 \\
\hline $\mathrm{D}$ & & & 2050 & 75 \\
\hline Average & & & 2575 & 94 \\
\hline Standard Deviation & & & 742.5 & 26.4 \\
\hline
\end{tabular}

Table 11: Student’s t.test for Field Samples

\begin{tabular}{|c|c|c|c|c|c|}
\cline { 2 - 6 } \multicolumn{1}{c|}{} & & 1 & 2 & 3 & 4 \\
\hline Ultrafuse $0.18 \mathrm{gal} / \mathrm{yd}^{2}$ & 1 & - & - & - & - \\
\hline Ultrafuse $0.13 \mathrm{gal} / \mathrm{yd}^{2}$ & 2 & 0.842 & - & - & - \\
\hline Ultrafuse $0.08 \mathrm{gal} / \mathrm{yd}^{2}$ & 3 & 0.608 & 0.612 & - & - \\
\hline CSS-1H & 4 & $\mathbf{0 . 0 3 7}$ & 0.128 & 0.062 & - \\
\hline
\end{tabular}

*Bold Indicates statistical difference at the 95\% confidence level. 
Table 12: I-64 Field Core Results

\begin{tabular}{|c|c|c|}
\hline Sample & $\begin{array}{c}\text { Testing } \\
\text { Temperature }\end{array}$ & $\begin{array}{c}\text { Bond } \\
\text { Strength } \\
\text { (psi) }\end{array}$ \\
\hline 1 & 77 & 122.5 \\
\hline 2 & 77 & 136.8 \\
\hline 3 & 77 & 151.2 \\
\hline 4 & 71 & 196.7 \\
\hline 5 & 71 & 195.7 \\
\hline 6 & 19 & $>350$ \\
\hline
\end{tabular}




\section{CHAPTER 5 OBSERVATIONS AND RECOMMENDATIONS}

\subsection{OBSERVATIONS}

The first objective of this study was to fabricate a direct shear device and a standardized testing procedure for laboratory and field samples. This device, presented in Figure 4 was developed and tested in a laboratory study. This device and test method produced similar results to what has been published in the literature.

The second objective of this study was to determine the effects of differing the Nominal Mix Aggregate Size (NMAS), surface condition, presence of tack coat, tack coat type, curing time, and conditioning similar to the AASTHO T283 method. The following observations were made:

1. Compaction effort affects the bond strength.

2. The range of bond strengths measured were in a fairly small range, this may indicate the method of preparing the samples promoted good bond strengths which inhibited the investigation of the effects of other factors.

3. Rest period at room temperature between fabrication and testing affects bond strength.

4. Increasing the NMAS of the base layer increases the bond strength, but the difference is not statistically significant.

5. Milling the surface, in lab, did not produce higher shear strengths on average than the cut surface.

6. The presence of tack coat was only found to be statistically significant in comparison to no tack with SS-1h applied to a milled surface with a 0.25 hour set time.

7. A statistical difference was found between the bond strengths exhibited by NTSS$1 \mathrm{HM}$ and SS-1h at 0.25 hour cure time on a milled surface, but was not found for a cut surface. The NTSS-1hm showed higher bond strengths.

8. Tack coat set time shows a statistical significant difference on the bond strength of asphalt overlays. 
9. Conditioning samples with a method similar to the AASHTO T283 reduced the bond strength a statistically significant amount.

10. Laboratory fabricated samples exhibited higher bond strengths than field samples.

Some of these observations, such as the presence of tack coat not being a statistically significant factor, are counter intuitive. However, the abundance of literature on this subject demonstrates the complexity of this topic. Some researchers report tack coat improves bond strength while the results of others were similar the results report herein.

\subsection{RECOMMENDATIONS}

This research was limited to one aggregate source, two mix designs for the supporting layer and one for the top layer, two tack coat materials, and limited field data. With respect to laboratory work, further research could be conducted to analyze the following:

1. Investigate laboratory method of sample preparation that better simulates field conditions.

2. Investigate a different method of simulating milling in a laboratory setting.

3. Use different mix designs from different contractors (this study was limited to two mix designs from the same contractor using one source of aggregate).

4. Optimize a target tack coat application rate for materials typical to West Virginia by varying the application rate for a certain tack coat applied to a certain existing surface.

5. Investigate the effects of conditioning time at room temperature to determine an optimal rest period for both field and laboratory cores.

6. Further evaluate the effect of environmental conditioning on bond strength, e.g. do the air voids of the surface layer affect results.

However, developing a methodology for measuring and interpreting results from field cores is a more significant issue. Therefore, a field study should be performed which addresses the following considerations:

1. Field method for measuring tack coat application rate at specific locations. 
2. Wait period between paving and coring, should this be a function of ambient temperature when paving.

3. Core depth, full depth versus partial depth cores.

4. Specify method for transporting cores from the field to the lab.

5. Method and temperature for storing the cores in the lab.

6. Time between coring and testing.

7. Soak time in a water bath to ensure cores are at consistent temperature throughout.

8. Number of replicates required for statistically meaningful results.

9. Are separate cores required for density and bond strength testing.

10. Winter weather cycle reduce bond strength

11. Minimum bond strength criteria 


\section{REFERENCES}

Al-Qadi, I. L., K.I. Hasiba., A.S. Cortina., H.Ozer., and Z. Leng. Federal Highway Administration. Illinois Department of Transportation. BEST PRACTICES FOR IMPLEMENTATION OF TACK COAT: PART 1, LABORATORY STUDY. Springfield I, 2012a

Al-Qadi, I. L., A.S. Cortina., Hasiba., K.I. H. Ozere., and Z. Leng. Federal Highway Administration, Illinois Department of Transportation. Center for Transportation Infrastructure Systems. BEST PRACTICES FOR IMPLEMENTATION OF TACK COAT: PART 2, FIELD STUDY. Springfield Il: , 2012b

Al-Qadi, I. L., S.H.Carpenter., Z. Leng., and H.Ozer. Federal Highway Administration. Illinois Department of Transportation. Tack Coat Optimization for HMA Overlays. Springfield IL: , 2008.

Bae, A., L. Mohammad., M.A. Elseifi., J. Button., and N. Patel. "Effects of Temperature on Interface Shear Strength of Emulsified Tack Coats and Its Relationship to Rheological Properties." Transportation Research Record: Journal of the Transportation Research Board. 2180. (2010): 102-109.

Blacklidge Emulsions. NTSS-1HM Asphalt Emulsion Product Data Sheet. N.p.: Blacklidge Emulsions, 2008. Http://www.blacklidgeemulsions.com/Products/Specification \%20of\%20NTSS-1hm\%208-28-07.pdf. Web. 16 July 2013.Brown, E. R., P.S. Kandhal., F.L.Roberts.,Y.R. Kim., D.Y. Lee., and T.W. Kennedy. Hot Mix Asphalt Materials, Mixture Design, and Construction. 3rd ed. Lanham, Maryland: NAPA Research and Education Foundation, 2009.

Buchanan, M. S.,. and M.E. Woods., Mississippi Transportation Research Center. Report No. FHWA/MS-DOT-RD-04-168: Field Tack Coat Evaluator (ATACKer ${ }^{\mathrm{TM}}$ ). Jackson, MS, 2004.

Chen, Jian-Shiuh, and C.C. Huang. "Effect of Surface Characteristics on Bonding Properties of Bituminous Tack Coat." Transportation Research Record: Journal of the Transportation Research Board. 2180. (2010): 142-149.

Deysarkar, I., and V. Tandon., Center for Transportation Infrastructure Systems. Report No. FHWA/TX-04/0-4129-1: Development of an Objective Field Test to Determine Tack Coat Adequacy. Austin, TX. 2004.

Global Gilson. Web. 15 July 2013. http://www.globalgilson.com/productdisplay.asp?model=MS-42>.

Hakimzadeh, S., W.G. Buttlar., R Santarromana. "CharaShear- and Tension-Type Tests to Evaluate Bonding of Hot-Mix Asphalt Layers with Different Tack Coat Application Ratescterization of Asphalt Concrete Layer Interfaces." Transportation Research Record: Journal of the Transportation Research Board. 2295. (2012): 54-62. 
HMA Lab Supply.., 2013. Web. 15 July 2013. ttp://www.hmalabsupply.om/index.php? page=shop.product_details\&flypage=shop.flypage\&product_id=614\&category_id=ef31b ba8599aa429297fcb0343a52d1d\&option=com_phpshop\&Itemid=1 > .

Hughes, C. S., K.K McGhee., and Maupin. "The Next Step Toward End-Result Specifications for Hot-Mix Asphalt Materials and Construction." Virginia Transportation Research Council Research Report 07-R26. 07.R26 (2007): n. page.

Kim, H, M. Arraigada., C. Raab., and M.N.Partl. "Numerical and Experimental Analysis for the Interlayer Behavior of Double-Layered Asphalt Pavement Specimens." JOURNAL OF MATERIALS IN CIVIL ENGINEERING (C) ASCE. 23.1 (2011): 12-20.

Kruntcheva, M R, A.C. Collop., and N.H.Thom. "Properties of Asphalt Concrete Layer Interfaces." JOURNAL OF MATERIALS IN CIVIL ENGINEERING (C) ASCE. 18.3 (2006): 467-471.

McGhee, K. K., and T.M.Clark. "Bond Expectations for Milled Surfaces and Typical Tack Coat Materials Used in Virginia." Virginia Transportation Research Council Research Report 09-R21. 09.R21 (2009): n. page.

Miro R. R., J.F. Perez., and G. Borras. 2003. Evaluation of the effect of tack coats. LCB Shear Test $6^{\text {th }}$ RILEM Symposium PTEBM’03., Zurich Switzerland, pp550-556.

Mohammad, L. N., M. Hassan., and N. Patel. "Effects of Shear Bond Characteristics of Tack Coats on Pavement Performance at the Interface." Transportation Research Record: Journal of the Transportation Research Board. 2209. (2011): 1-8.

Mohammad, L., Elseifi., Bae., and Patel. National Research Council. NCHRP Report 712: Optimization of Tack Coat for HMA Placement. Washington, DC: The National Academies Press, 2012.

Raab, C., andM.N. Partl. "Interlayer Shear Performance: Experience With Different Pavement Structures." 3rd Eurasphalt \& Eurobitume Congress Vienna. Dubendorf, switzerland: 2004. 535-545.

Raab, C., and M.N.Partl. Effect of tack coats on the interlayer shear bond of pavements. 8th conference of Asphalt Pavements for Southern African (CAPSA '04) Sun City, South Africa, Document Transformation Techniologies cc. 847-855. ISBN 1-920-01718-6. 2004.

Santucci, L., P.E. Recent Findings on the Use of Tack Coat Between Pavement Layers. Publication. Vol. 1. Davis - Berkley: University of California, Pavement Research Center, 2009.

Sholar, G. A., G.C. Page., J.A.Musselman., P.B.Upshaw., and Moseley. Preliminary Investigation of a Test Method to Evaluate Bond Strength of Bituminous Tack Coats. Journal of the Association of Asphalt Paving Technologies Vol 73, pp 771-801. 
Solaimanian, M., Phd. P.E. Paving the Way. Issue brief. HARRISBURG: PENNSYLVANIA ASPHALT PAVEMENT ASSOCIATION, 2013.. Jan-Mar 2013.

Sutradhar, B. B., Panda., and Das. "Laboratory study to investigate the performance of Tack Coat between bituminous layers ." IOSR Journal of Mechanical and Civil Engineers. 4.6 (2013): 45-53.

Tashman, L., K. Nam., and T.Papagiannakis. Evaluation of the Influence of Tack Coat Construction Factors on the Bond Strength between Pavement Layers. Pullman, Washington. Washington Center for Asphalt Technology. 2006.

Taylor, A. Joel, and J.R.Willis. EFFECTS OF NANOTAC ADDITIVE ON BOND STRENGTH AND MOISTURE RESISTANCE OF TACK COATS. Auburn Alabama: National Center for Asphalt Technology, 2011.

Tran, N. H., R.Willis., and G. Julian. National Center for Asphalt Technology. NCAT Report No. 12-04: Refinement of the Bond Strength Procedure and Investigation of a Specification. Auburn, Alabama, 2012

Wang, H., I.L.Al-Qadi., and I.Stanciulescu. Effect of Friction on Rolling Tire - Pavement Interaction. Rep. N.p.: Purdue University, 2010.

West, R.C, J.Zhang., and J.Moore. Alabama Department of Transportation. National Center for Asphalt Technology. EVALUATION OF BOND STRENGTH BETWEEN PAVEMENT LAYERS. Auburn Alabama: National Center for Asphalt Technology, 2005.

Wheat, M. EVALUTATION OF BOND STRENGTH AT ASPHALT INTERFACES. MS thesis. Kansas State University, Manhattan, Kansas: 2007. 
APPENDIX 1: BOND STRENGTH TESTING DEVICE TECHNICAL DRAWINGS

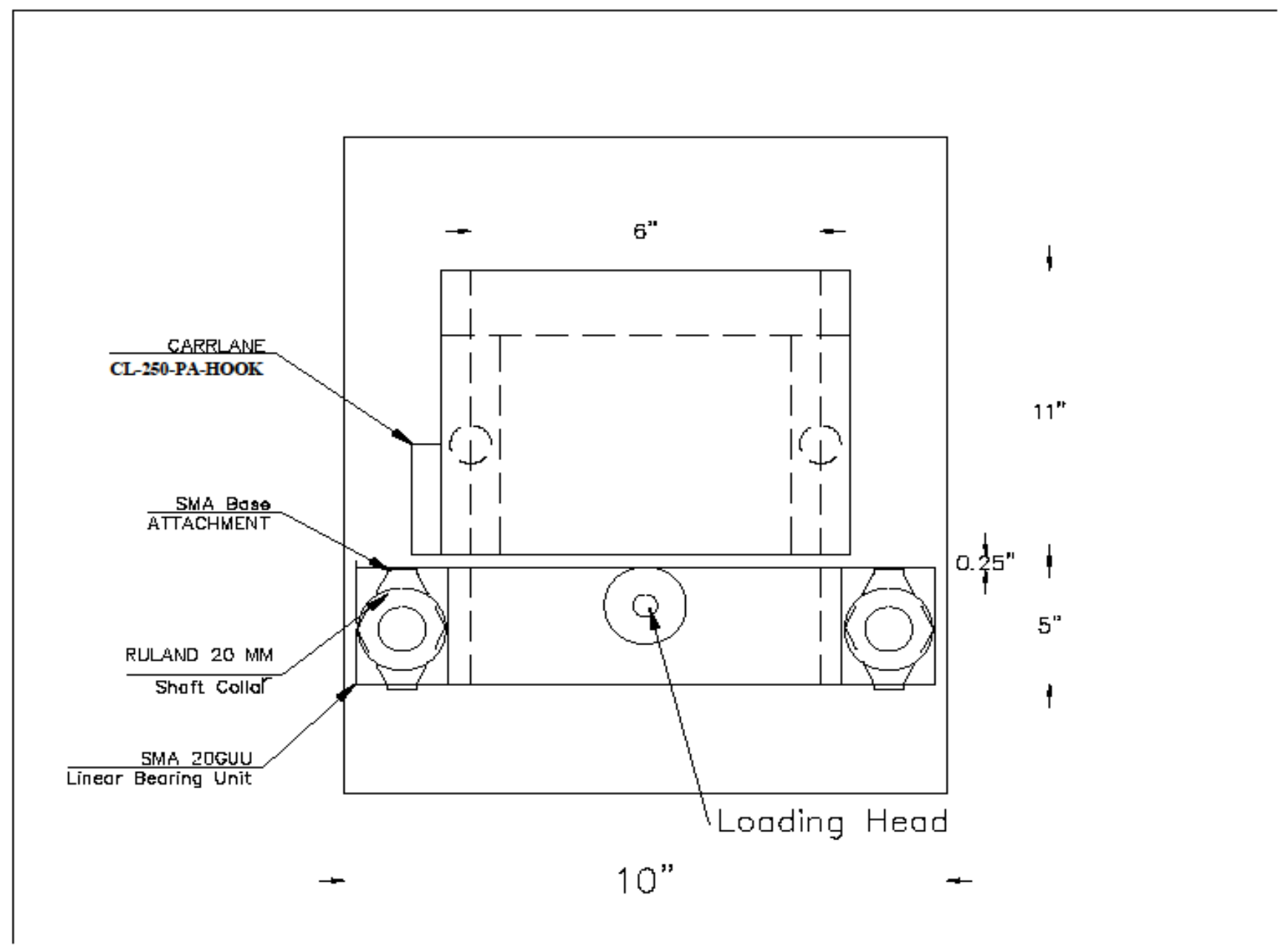




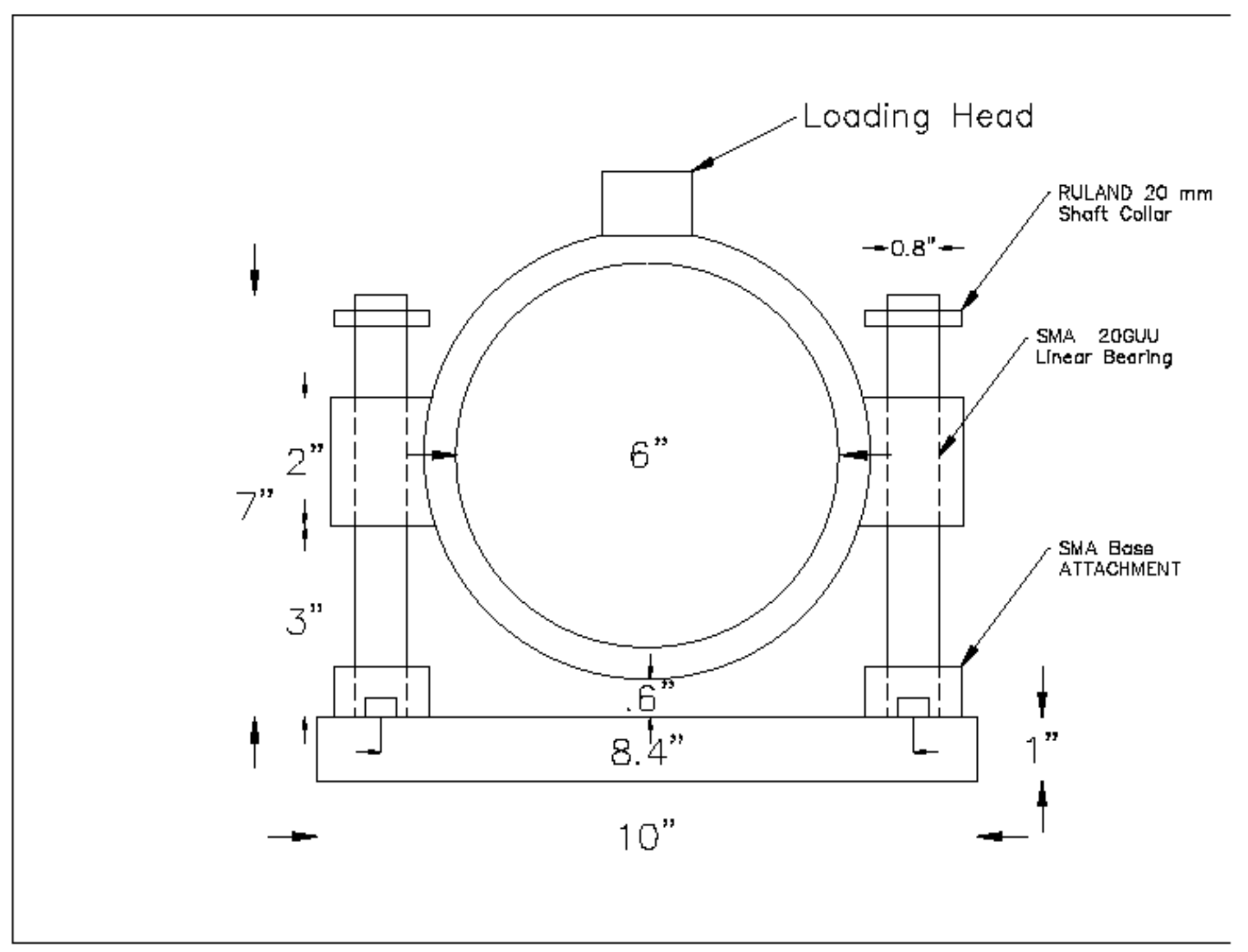




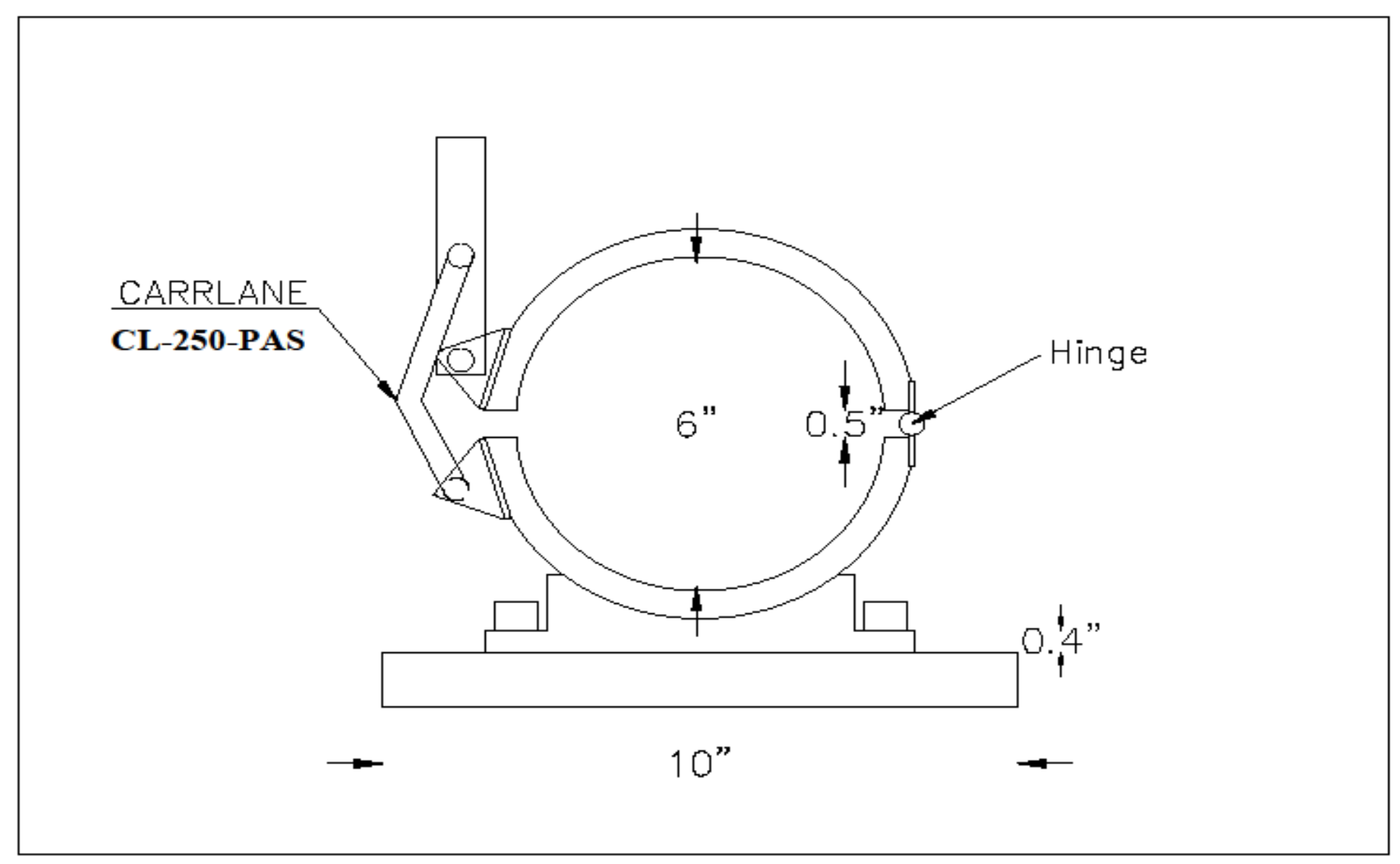




\title{
APPENDIX 2: BOND STRENGTH TESTING PROCEDURE
}

\author{
WEST VIRGINIA DEPARTMENT OF TRANSPORTATION \\ DIVISION OF HIGHWAYS \\ MATERIALS CONTROL, SOILS AND TESTING DIVISION \\ MATERIALS PROCEDURE
}

\section{GUIDE TO DETERMINING INTERFACE BOND SHEAR STRENGTH OF MULTI- LAYEREDASPHALT PAVEMENT SPECIMENS}

\section{PURPOSE}

1.1 To establish an approved method for determining the interface bond shear strength between layers of asphalt concrete pavement in cored samples taken from the roadway

\section{SCOPE}

2.1 This test method covers the determination of the interface bond shear strength between layers of asphalt concrete pavement in cored samples of both Marshall and Superpave mixes.

2.2 This test method is applicable for cores obtained from both newly constructed and previously existing asphalt concrete pavements. It could also be used to determine the interface bond strength between asphalt concrete and Portland cement concrete.

2.3 This test is applicable on six-inch diameter cores that are not less than two inches thick

\section{REFERENCED DOCUMENTS}

3.1 AASHTO Standards:

- T-168, Standard Practice for Sampling Hot-Mix Asphalt Paving Mixtures

- T-245, Standard Method of Test for Resistance to Plastic Flow of Bituminous Mixtures Using Marshall Apparatus

\subsection{ASTM Standards}

- D 5581, Resistance to Plastic Flow of Bituminous Mixtures Using Marshall Apparatus (6 inch- Diameter Specimen)

\section{APPARATUS}

4.1 Bond Test Device - The device used for the bond shear test shall be designed to accommodate six-inch diameter test specimens. The device shall have a methal cylindrical specimen holder (reaction frame) and a movable specimen holder (shearing frame). The reaction frame shall have the capabilities to tightly hold samples slightly 
smaller than six-inches. The shearing frame shall move freely through the use of friction reduced bearings. The shearing frame shall have a spherical loading head. The gap between the reaction frame and the shearing frame shall be $1 / 4$ inch $\pm 1 / 32$ inch. Illustrated in Figure 1.

4.2 Loading Machine - The loading machine shall produce a uniform vertical movement of two inches per minute. The Marshall Stability test apparatus or other mechanical or hydraulic testing machine may be used provided the rate of movement is maintained at two inches per minute while the load is being applied.

\subsection{Wet masonry saw.}

4.4 White or silver paint (see 6.3)

4.5 Supply of MP 401.07.23 data sheets

5. Rounding of Data

11.1 The test data and calculations are rounded to the following nearest significant digit.

$\begin{array}{ll}\text { Station Number } & 1 \mathrm{ft} \text { (not on data sheet) } \\ \text { Diameter } & 0.05 \mathrm{in} \\ \text { Thickness of Overlay } & 0.05 \mathrm{in} \\ \text { Thickness of Existing HMA } & 0.05 \mathrm{in} \\ \text { Max Load Applied } & 1 \mathrm{lb} \\ \text { Cross Sectional Area } & 1 \mathrm{in}^{2} \\ \text { Bond Shear Strength } & 1 \mathrm{psi} \\ \text { Average Bond Shear Strength } & 1 \mathrm{psi} \\ \text { Standard Deviation } & 0.1 \mathrm{psi}\end{array}$

\section{PREPARATION OF TEST SPECIMENS}

6.1 Number of Test Specimens - a single test procedure shall consist of at least three specimens.

6.2 Each roadway core specimen shall be six inches in diameter with the entire surface of the perimeter perpendicular to the tope surface of the core within $1 / 4$ inch. The core should be drilled through the entire depth of the bound materials. If the height of the core above or below the interface being tested is greater than three inches, it shall be trimmed with a wet masonry saw to a height of approximately three inches. 
6.3 Identify the location of the interface layer with white or silver paint with three equally spaced marks approximately one inch long around the perimeter of each core.

\section{PROCEDURE}

6.1 Specimen dimensions - measure the diameter of the core and the thickness of the overlay to the nearest 0.05 inch. Measure the diameter in at least three locations and average the readings.

6.2 Specimen conditioning - allow the specimens to stabilize at the test temperature of $77 \pm 2^{\circ} \mathrm{F}\left(25 \pm 1^{\circ} \mathrm{C}\right)$ for a minimum of 40 minutes in a water bath in an enclosed leak-proof bag to protect it from getting wet.

6.3 Specimen positioning - orient the c ore in the bond strength device so that the direction so that the direction of traffic marked on the core is vertically pointing upward and the marked interface is centered between the edge of the reaction frame and the edge of the shearing frame.

6.3.1 Align the loading head adjacent to the bonded interface. The loading head shall rest parallel to the bonded interface on the asphalt overlay portion of the specimen. Sample positioning and loading is shown in Figure 1.

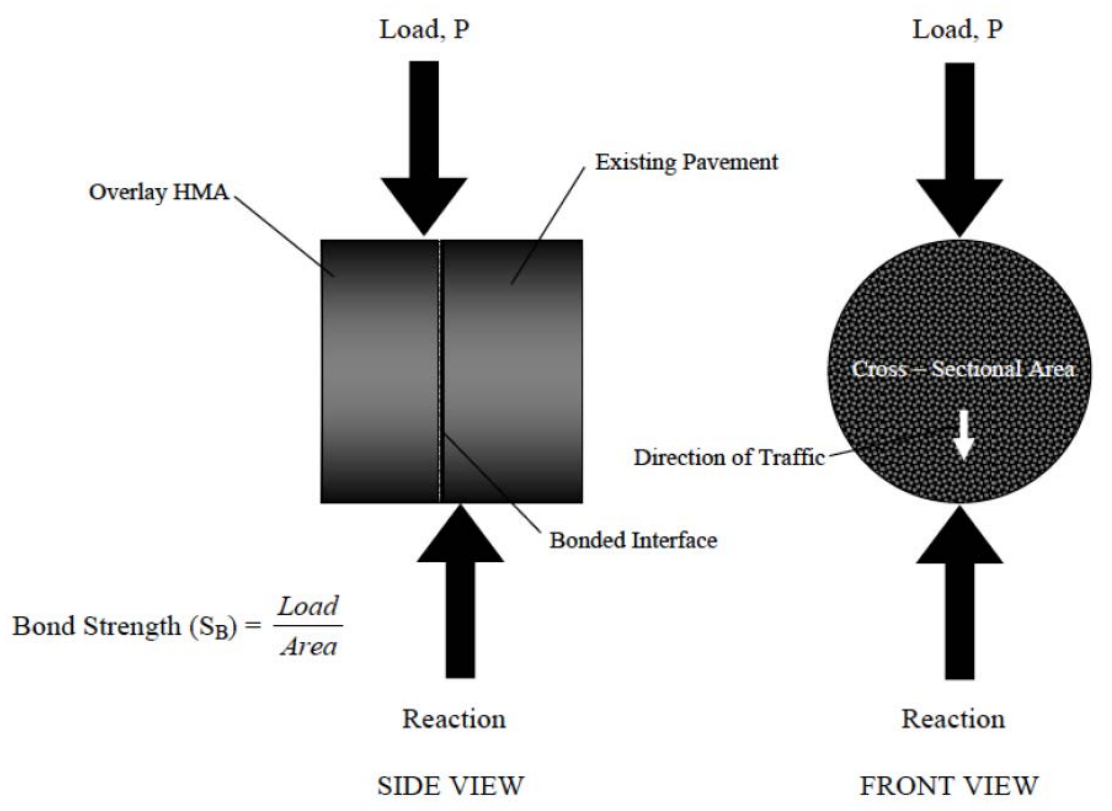

Figure 1: Loading Scheme Used for Bond Strength Test

6.4 Rate of displacement - Apply the displacement continuously and without shock at a constant strain rate of two inches per minute until failure occurs. Record the maximum load in pounds, $\mathrm{P}_{\mathrm{MAX}}$, carried by the specimen during the test. 


\section{CALCULATION}

Calculate the bond shear strength, $\mathrm{S}_{\mathrm{B}}$, as follows:

Where:

$$
\mathrm{S}_{\mathrm{B}}=\mathrm{P}_{\mathrm{MAX}} / \mathrm{A}
$$

$\mathrm{S}_{\mathrm{B}}=$ bond shear strength, pounds per square inch (psi)

$\mathrm{P}_{\mathrm{MAX}}=$ maximum load applied to the specimen, pounds-force (lbf)

$\mathrm{A}=$ cross sectional area of test specimen, square inches $\left(\mathrm{in}^{2}\right)$

And:

$$
\mathrm{A}=\pi \mathrm{D}^{2} / 4
$$

Where:

$A=$ cross-sectional area of test specimen, square inches $\left(i^{2}\right)$

$\mathrm{D}=$ average diameter of test specimen, inches (in)

\section{REPORT}

8.1 Record each core number or identification, sampling date, and test date.

8.2 Failure surface. Identify if failures occurred at the interface, in the existing layer, or in the overlay of each core.

8.3 Note the appearance of the interface including any contaminants, milling striations, stripping, tack coat streaks, or other observations.

8.4 Record the test results for each core.

8.4.1 Specimen dimensions - including thickness of the overlay asphalt, thickness of the existing layer, the average diameter, and the cross-sectional area.

8.4.2 Maximum load applied.

8.4.3 Bond shear strength, rounded to the nearest psi.

8.5 Calculate and record the mean and standard deviation of the bond strength for the set of cores. 


\section{APPENDIX 3: PREPARATION OF LABORATORY SAMPLES}

GUIDE TO LABORATORY FRABRICATION OF BOND STRENGTH SAMPLES

\section{PURPOSE}

1.1 To establish an approved method for fabricating laboratory samples for testing of interface bond strength.

11. SCOPE

2.1 This method covers the fabrication process for interface bond strength samples.

2.2 This test shall be performed on $150 \mathrm{~mm}$ diameter Superpave samples.

\section{REFERENCED DOCUMENTS}

3.2 AASHTO Standards:

- $\quad$ R 30 Mixture Conditioning of Hot Mix Asphalt (HMA)

- T 166 Bulk Specific Gravity of Compacted Hot Mix Asphalt (HMA) using Saturated Surface-Dry Specimens

- T 209 Theoretical Maximum Specific Gravity and Density of Hot Mix Asphalt (HMA)

- T-245, Standard Method of Test for Resistance to Plastic Flow of Bituminous Mixtures Using Marshall Apparatus

\subsection{ASTM Standards}

- $\quad$ D 5581, Resistance to Plastic Flow of Bituminous Mixtures Using Marshall Apparatus (6 inch-Diameter Specimen)

\section{APPARATUS}

\subsection{Wet masonry saw.}

13.3 Superpave Gyratory Compactor, including a device for measuring and recording the height of the specimen throughout the compaction process. The compactor may also include a printer or a computer and software for collecting and printing data.

13.4 Specimen molds

13.5 Thermometer

13.6 Balance readable to 1 gram

13.7 Ovens 
13.8 Calibration equipment recommended by compactor manufacturer

13.9 Safety equipment: insulated gloves, long sleeves, etc.

13.10 Miscellaneous equipment: paper discs, lubricating materials recommended by compactor manufacturer, scoop or trowel for moving mixture, funnel or other device for ease of loading mixture into the mold (optional).

\section{PROCEDURE}

5. 1 Weigh out the appropriate amounts of the required aggregate size fractions and combine in a bowl to the proper batch weight. Typically, a batch weight of $4500-4700$ grams of aggregate with provide enough material for a finished height of $115 \pm 5 \mathrm{~mm}$, if the combined aggregate specified gravity is between $2.55-2.70$.

5. 2 Heat the asphalt binder and the combined aggregate in an oven to the appropriate mixing temperature for the binder used. This temperature can be determined from an equiviscous temperature chart or may be provided by the binder supplier. The appropriate temperature range for mixing is defined as the range of temperature that produces a viscosity of $0.17 \pm 0.02 \mathrm{~Pa}$-s for the unaged binder. This ensures that the binder is fluid enough to coat the aggregate particles. Some modified binders do not follow these temperature-viscosity relationships; the manufacturer's recommendations should be followed.

5. 3 The heated aggregate should be placed in the mixing bowl and thoroughly dry mixed. Make a crater in the center of the aggregate in the bowl and weigh in the required amount of asphalt binder. Begin mixing immediately.

5. 4 A mechanical mixer is recommended for preparing laboratory mixtures because mixing such a large quantity of material by hand is difficult. Mixing should continue until the asphalt binder is uniformly distributed over the aggregate particles.

5. 5 Determine the proper compaction temperature range for the asphalt binder used. This is defined as the range of temperatures that yields a binder viscosity of $0.28 \pm 0.03$ Pa-s. Some modified binders do not follow these temperature-viscosity relationships; the manufacturer's recommendations should be followed.

5. 6 After mixing, spread the loose mixture in a flat, shallow pan and short term condition the mixture as detailed in AASHTO R30 Standard Practice for Mixture Conditioning of Hot Mix Asphalt (HMA).

5. 7 Place the compaction mold and base plate in an oven to preheat at the required compaction temperature for a period of 30 to 60 minutes prior to the start of compaction.

5. 8 After the mixture comes to the proper compaction temperature, proceed with compaction in the gyratory as outlined below.

5. 9 Ensure the gyratory compactor has been turned on and allowed to warm up for the time recommended by the manufacturer. Verify all settings for angle, pressure and number of gyrations.

5. 10 Verify that the height recording device is turned on and is reading in the proper units. Height calibration should be verified daily.

5. 11 When the compaction temperature has been reached, remove the mold and base plate from the oven. Put the base plate in position in the mold and place a paper disk in the bottom of the mold. 
5. 12 Charge the mixture into the mold in one lift. A funnel or other device may be used to place the mixture into the mold. Take care to avoid segregating the mix in the mold, but work quickly so that the mixture does not cool excessively during loading. Level the mix in the mold and place a paper disk on top. Place the top plate if needed.

5. 13 Place the mold in the gyratory as per manufacturer's recommendations. (Some gyratory allow charging the mold with mix after the mold has been positioned in the compactor). Lubricate the mold or gyratory parts as recommended by manufacturer.

5. 14 Apply the load to the mixture in the mold; the pressure applied should be $600 \pm 18 \mathrm{kPa}$.

5. 15 Apply the standard gyratory angle to the mold.

5. 16 Input the number of desired gyrations.

5. 17 The gyratory will stop automatically when the specified number of gyrations has been reached. Remove the mold from the compactor, if required, and extrude the specimen from the mold. Take care not to distort the specimen when removing the specimen from the mold. A cooling period of 5 to 10 minutes may be necessary with some mixtures; a fan may help speed the cooling process. Remove the paper disks while the specimen is still warm to avoid excessive sticking.

5. 18 Prepare a loose sample of the same mixtures and determine the maximum theoretical specific gravity, $\mathrm{G}_{\mathrm{mm}}$, in accordance with AASHTO T209, Maximum Specific Gravity of Bituminous Paving Mixture.

5. 19 Measure and record the mass of the compacted specimen to the nearest 1 gram. Determine the bulk specific gravity $\left(\mathrm{G}_{\mathrm{mb}}\right)$ of the compacted specimen in accordance with AASHTO T166, Bulk Specific Gravity of Compacted Bituminous Paving Mixtures Using Saturated Surface Dry Specimens.

5. 20 These samples will be representative of the "supporting layer" for the double layered bond strength specimens.

5. 21 Take the full height sample and cut in half across the diameter to produce two equal height samples for the supporting layers.

5. 22 To simulate different supporting layer interface conditions, either the freshly molded face, cut face or a milling procedure can be performed to simulate different conditions.

5. 23 To produce to "top layer" of the sample, steps 1 through 21 is followed with several exceptions. First a smaller amount of aggregate and binder is necessary, since only half height samples will be compacted on top of the "supporting layer".

5. 24 After mixing and conditioning, prior to compaction the mold is removed from the oven and the "supporting layer" is placed into the mold on top of the bottom platen and paper disc, prior to placing the virgin mix on top of it.

5. 25 If tack coat is to be applied to the supporting layer, the tack should be placed evenly across the entire surface of the interface prior to placing the supporting layer into the SGC mold.

5. 26 The virgin mix is placed on top of the "supporting layer" and the temperature is recorded.

5. 27 The top paper disc and top plate are placed in the mold, and the sample is compacted in the SGC.

5. 28 Initial tests shall be performed to investigate the effects of compaction on the voids in the top layer of the sample, since $4 \%$ air voids is the target air content for both layers. Two samples are produced using the procedure outline above for compaction efforts of 40, 60, and 80 gyrations. These gyration levels pertain to compaction the top layer since the bottom was already fabricated. 
The samples are removed from the mold, and allowed to cool to room temperature. The bulk specific gravity of the entire sample is determined using AASHTO T166, and using the equation below, the approximate voids in the top layer is determined.

$$
\begin{gathered}
\mathrm{VTM}_{\mathrm{TOP}}=\frac{P_{\text {top }}}{\frac{100}{\mathrm{VTM}_{\mathrm{Total}}}-\frac{P_{\text {bottom }}}{\mathrm{VTM}_{\text {Supporting }}}} \\
\text { where percent top and perfecnt bottom are percent of total mass }
\end{gathered}
$$

The result of these test are used to make a graph, plotting compaction effort on the $\mathrm{x}$ axis and air void content on the $\mathrm{y}$ axis. The $4 \%$ target air void content is extrapolated across the graph to the compaction effort that results in this air void content. This compaction level is used for the remainder of the tests.

6.30 Store the samples for a 24 hour rest period at room temperature prior to testing for bond strength.

6.31 Place the samples are then placed in a leak proof plastic bag and place in a water bath at $77^{\circ} \mathrm{F}$ for a minimum of 40 minutes.

6.32 Removed from the water bath and the bag, then test for bond strength following MP 401.07.23. 


\section{APPENDIX 4: 9.5 MM AND 19 MM AGGREGATE BLENDS}

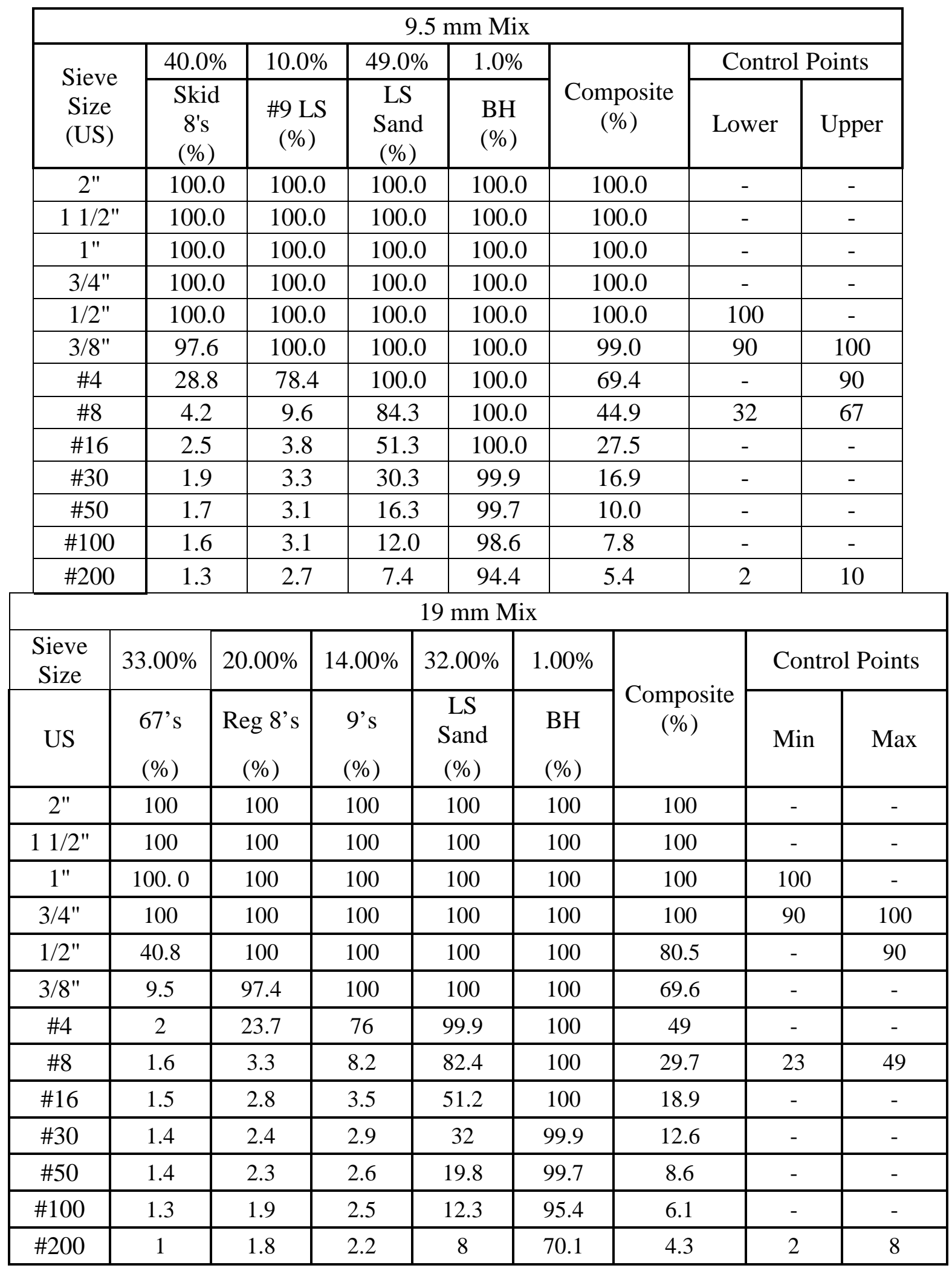


APPENDIX 5: MILLED SURFACE MACROTEXTURE

\begin{tabular}{|c|c|c|c|c|c|c|}
\hline & Supporting & Top & $\begin{array}{l}\text { Surface } \\
\text { Condition }\end{array}$ & $\begin{array}{c}\text { Mass of } \\
\text { Beads }\end{array}$ & $\begin{array}{c}\text { Volume } \\
\text { of Beads } \\
\left(\mathrm{mm}^{3}\right)\end{array}$ & $\begin{array}{l}\text { AMTD } \\
(\mathrm{mm})\end{array}$ \\
\hline 1 & 9.5 & 9.5 & Milled & 54.9 & 22217.73 & 1.3 \\
\hline 3 & 9.5 & 9.5 & Milled & 52.3 & 21165.52 & 1.2 \\
\hline 5 & 9.5 & 9.5 & Milled & 52.1 & 21084.58 & 1.2 \\
\hline 6 & 9.5 & 9.5 & Milled & 55.3 & 22379.6 & 1.3 \\
\hline 7 & 9.5 & 9.5 & Milled & 53 & 21448.81 & 1.2 \\
\hline 11 & 9.5 & 9.5 & Milled & 61.7 & 24969.65 & 1.4 \\
\hline 13 & 9.5 & 9.5 & Milled & 54.6 & 22096.32 & 1.3 \\
\hline 17 & 9.5 & 9.5 & Milled & 59.7 & 24160.26 & 1.4 \\
\hline 18 & 9.5 & 9.5 & Milled & 58 & 23472.28 & 1.3 \\
\hline 19 & 9.5 & 9.5 & Milled & 64 & 25900.45 & 1.5 \\
\hline 20 & 9.5 & 9.5 & Milled & 53 & 21448.81 & 1.2 \\
\hline 22 & 9.5 & 9.5 & Milled & 57.3 & 23188.99 & 1.3 \\
\hline 23 & 9.5 & 9.5 & Milled & 58.6 & 23715.1 & 1.3 \\
\hline 25 & 9.5 & 9.5 & Milled & 58.5 & 23674.63 & 1.3 \\
\hline 28 & 9.5 & 9.5 & Milled & 58.8 & 23796.03 & 1.3 \\
\hline 30 & 9.5 & 9.5 & Milled & 55.6 & 22501.01 & 1.3 \\
\hline 32 & 9.5 & 9.5 & Milled & 57.3 & 23188.99 & 1.3 \\
\hline 38 & 9.5 & 9.5 & Milled & 60.1 & 24322.14 & 1.4 \\
\hline 40 & 9.5 & 9.5 & Milled & 54 & 21853.5 & 1.2 \\
\hline 41 & 9.5 & 9.5 & Milled & 62.9 & 25455.28 & 1.4 \\
\hline 43 & 9.5 & 9.5 & Milled & 56.2 & 22743.83 & 1.3 \\
\hline 45 & 9.5 & 9.5 & Milled & 60.8 & 24605.42 & 1.4 \\
\hline 47 & 9.5 & 9.5 & Milled & 58.5 & 23674.63 & 1.3 \\
\hline 49 & 9.5 & 9.5 & Milled & 59.3 & 23998.38 & 1.4 \\
\hline
\end{tabular}


APPENDIX 6: RAW DATA

\begin{tabular}{|c|c|c|c|c|c|c|c|c|c|c|c|c|c|c|c|c|c|c|c|c|}
\hline $\begin{array}{l}\frac{0}{0} \\
\frac{\frac{1}{n}}{0} \\
\sim\end{array}$ & 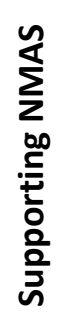 & 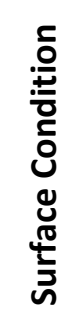 & 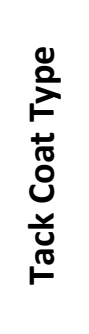 & 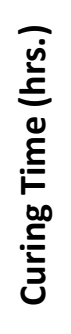 & 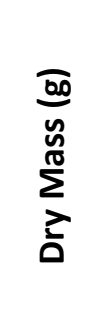 & 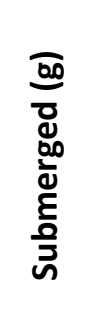 & $\begin{array}{l}\frac{\sqrt[00]{0}}{n} \\
\text { n }\end{array}$ & 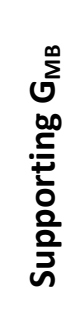 & 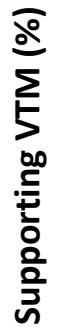 & 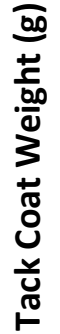 & 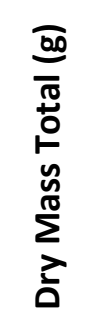 & 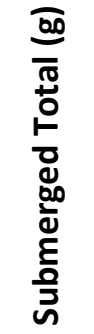 & 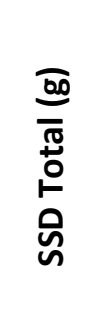 & $\frac{\sum^{\infty}}{\stackrel{0}{\pi}}$ & 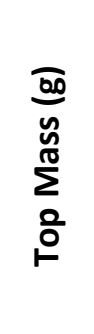 & 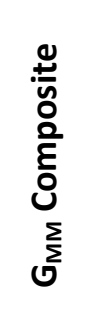 & 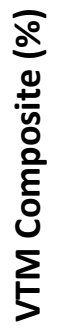 & $\begin{array}{l}\overline{0} \\
\frac{0}{0} \\
\frac{1}{2} \\
\sum \\
5\end{array}$ & 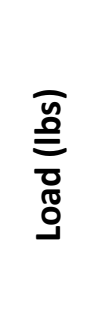 & 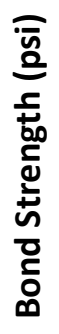 \\
\hline 1 & 9.5 & Milled & $\begin{array}{l}\text { NTSS- } \\
1 \mathrm{HM}\end{array}$ & 0.25 & 2188.2 & 1244.1 & 2191.5 & 2.310 & 6.9 & 9.2 & 4588.2 & 2623.3 & 4595.6 & 2.326 & 2390.8 & 2.487 & 6.5 & 6.1 & 5400.0 & 197 \\
\hline 2 & 9.5 & $\begin{array}{l}\text { Cut } \\
\text { Face }\end{array}$ & SS-1h & 2 & 2370.5 & 1364.8 & 2376.1 & 2.344 & 5.6 & 3.6 & 4773.6 & 2745.5 & 4779.4 & 2.347 & 2399.5 & 2.484 & 5.5 & 5.5 & 5300.0 & 193 \\
\hline 3 & 9.5 & Milled & SS-1h & 2 & 2306.4 & 1315.1 & 2310.2 & 2.318 & 6.6 & 9.2 & 4702.9 & 2705.2 & 4707.2 & 2.349 & 2387.3 & 2.487 & 5.5 & 4.8 & 4400.0 & 161 \\
\hline 4 & 9.5 & $\begin{array}{l}\text { Cut } \\
\text { Face }\end{array}$ & None & 0 & 2391.1 & 1377 & 2396.8 & 2.345 & 5.5 & 0.0 & 4776.4 & 2752.4 & 4785.1 & 2.350 & 2385.3 & 2.482 & 5.3 & 5.1 & 4900.0 & 179 \\
\hline 5 & 9.5 & Milled & $\begin{array}{l}\text { NTSS- } \\
1 \mathrm{HM}\end{array}$ & 0.25 & 2318.9 & 1338.2 & 2322.3 & 2.356 & 5.1 & 9.2 & 4725.2 & 2722.8 & 4737.8 & 2.345 & 2397.1 & 2.487 & 5.7 & 6.5 & 5700.0 & 208 \\
\hline 6 & 9.5 & Milled & None & 0 & 2435.3 & 1409 & 2437.9 & 2.367 & 4.6 & 0.0 & 4825.7 & 2783.1 & 4833.1 & 2.354 & 2390.4 & 2.482 & 5.2 & 5.8 & 5500.0 & 201 \\
\hline 7 & 9.5 & Milled & $\begin{array}{l}\text { NTSS- } \\
1 \mathrm{HM}\end{array}$ & 0.25 & 2275.8 & 1316.7 & 2278.9 & 2.365 & 4.7 & 9.2 & 4671.1 & 2692.5 & 4686.6 & 2.342 & 2386.1 & 2.487 & 5.8 & 7.4 & 5000.0 & 182 \\
\hline 8 & 19 & $\begin{array}{l}\text { Cut } \\
\text { Face }\end{array}$ & None & 0 & 2104 & 1222.2 & 2115.9 & 2.354 & 6.3 & 0.0 & 4493.6 & 2581.8 & 4512.7 & 2.327 & 2389.6 & 2.496 & 6.8 & 7.3 & 4500.0 & 164 \\
\hline 9 & 9.5 & $\begin{array}{l}\text { Cut } \\
\text { Face }\end{array}$ & $\begin{array}{l}\text { NTSS- } \\
1 \mathrm{HM}\end{array}$ & 0.25 & 2305.4 & 1326.2 & 2313.2 & 2.336 & 5.9 & 3.6 & 4796.5 & 2760.7 & 4805.4 & 2.346 & 2487.5 & 2.484 & 5.6 & 5.3 & 4900.0 & 179 \\
\hline 10 & 9.5 & $\begin{array}{l}\text { Cut } \\
\text { Face }\end{array}$ & SS-1h & 0.25 & 2407.4 & 1388.3 & 2412.4 & 2.351 & 5.3 & 3.6 & 4696.1 & 2699.6 & 4709.5 & 2.336 & 2285.1 & 2.484 & 5.9 & 6.8 & 4700.0 & 172 \\
\hline 11 & 9.5 & Milled & None & 0 & 2395.6 & 1385.3 & 2399.4 & 2.362 & 4.8 & 0.0 & 4789.1 & 2769.9 & 4793.0 & 2.367 & 2393.5 & 2.482 & 4.6 & 4.4 & 6000.0 & 219 \\
\hline 12 & 9.5 & $\begin{array}{l}\text { Cut } \\
\text { Face }\end{array}$ & SS-1h & 2 & 2252.3 & 1297.3 & 2257.4 & 2.346 & 5.5 & 3.6 & 4635.5 & 2666.0 & 4640.7 & 2.347 & 2379.6 & 2.484 & 5.5 & 5.5 & 5400.0 & 197 \\
\hline 13 & 9.5 & $\begin{array}{c}\text { Mille } \\
\mathrm{d}\end{array}$ & None & 0 & 2264.3 & 1311.1 & 2266.3 & 2.370 & 4.5 & 0.0 & 4656.9 & 2693.0 & 4662.7 & 2.364 & 2392.6 & 2.482 & 4.7 & 5.0 & 5200.0 & 190 \\
\hline 14 & 19 & $\begin{array}{l}\text { Cut } \\
\text { Face }\end{array}$ & None & 0 & 2341 & 1357.6 & 2350.8 & 2.357 & 6.2 & 0.0 & 4736.9 & 2728.9 & 4748.3 & 2.346 & 2395.9 & 2.497 & 6.0 & 5.9 & 5000.0 & 182 \\
\hline 15 & 9.5 & $\begin{array}{l}\text { Cut } \\
\text { Face }\end{array}$ & $\begin{array}{c}\text { NTSS- } \\
1 \mathrm{HM}\end{array}$ & 0.25 & 2321.3 & 1383.4 & 2326.1 & 2.462 & 0.8 & 3.6 & 4710.6 & 2708.3 & 4716.4 & 2.346 & 2385.7 & 2.484 & 5.6 & -1.1 & 5700.0 & 208 \\
\hline
\end{tabular}




\begin{tabular}{|c|c|c|c|c|c|c|c|c|c|c|c|c|c|c|c|c|c|c|c|c|}
\hline$\frac{\frac{0}{\alpha}}{\frac{\varepsilon}{E}}$ & 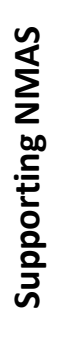 & 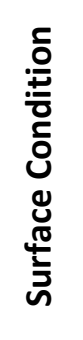 & 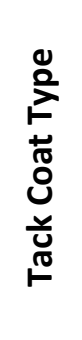 & 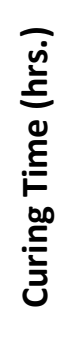 & 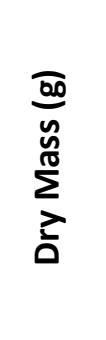 & 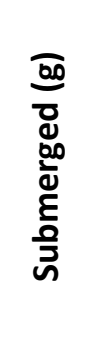 & $\begin{array}{l}\text { क0 } \\
\text { صै }\end{array}$ & 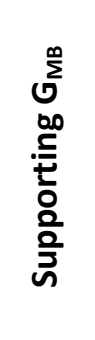 & 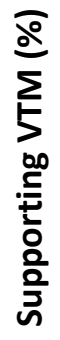 & 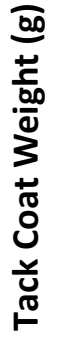 & 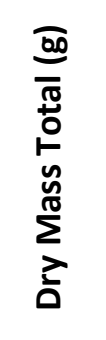 & 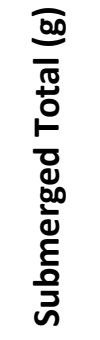 & 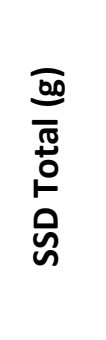 & $\frac{\sum_{0}^{\infty}}{\stackrel{\infty}{\pi}}$ & 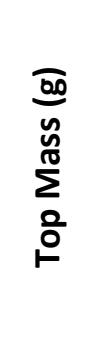 & 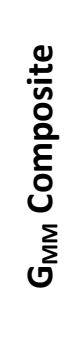 & 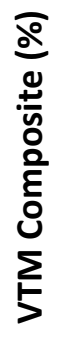 & $\begin{array}{l}\frac{\sqrt{0}}{80} \\
\stackrel{\circ}{0} \\
\stackrel{\Sigma}{5} \\
5\end{array}$ & 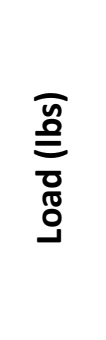 & 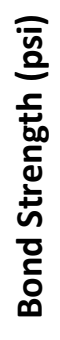 \\
\hline 16 & 19 & $\begin{array}{l}\text { Cut } \\
\text { Face }\end{array}$ & None & 0 & 2473.9 & 1447 & 2481.4 & 2.392 & 4.8 & 0.0 & 4870.7 & 2820.4 & 4878.1 & 2.367 & 2396.8 & 2.497 & 5.2 & 5.7 & 6200.0 & 226 \\
\hline 17 & 9.5 & $\begin{array}{c}\text { Mille } \\
\text { d }\end{array}$ & SS-1h & 0.25 & 2146.8 & 1242.9 & 2149.8 & 2.367 & 4.6 & 9.2 & 4541.0 & 2615.6 & 4546.3 & 2.352 & 2385.0 & 2.487 & 5.4 & 6.4 & 4600.0 & 168 \\
\hline 18 & 9.5 & $\begin{array}{c}\text { Mille } \\
\text { d }\end{array}$ & SS-1h & 0.25 & 2056.9 & 1174.6 & 2061.1 & 2.320 & 6.5 & 9.2 & 4456.7 & 2550.9 & 4460.9 & 2.333 & 2390.6 & 2.487 & 6.2 & 5.9 & 4900.0 & 179 \\
\hline 19 & 9.5 & $\begin{array}{c}\text { Mille } \\
\mathrm{d}\end{array}$ & None & 0 & 2341.9 & 1340.9 & 2345.2 & 2.332 & 6.0 & 0.0 & 4746.3 & 2724.4 & 4753.2 & 2.339 & 2404.4 & 2.482 & 5.7 & 5.5 & 5400.0 & 197 \\
\hline 20 & 9.5 & $\begin{array}{c}\text { Mille } \\
\mathrm{d}\end{array}$ & SS-1h & 2 & 2088.2 & 1210 & 2090.7 & 2.371 & 4.5 & 9.2 & 4493.2 & 2589.2 & 4500.6 & 2.351 & 2395.8 & 2.487 & 5.5 & 6.8 & 4600.0 & 168 \\
\hline 21 & 9.5 & $\begin{array}{l}\text { Cut } \\
\text { Face }\end{array}$ & $\begin{array}{l}\text { NTSS- } \\
1 \mathrm{HM}\end{array}$ & 0.25 & 2259.6 & 1308.9 & 2262.5 & 2.370 & 4.5 & 3.6 & 4647.7 & 2678.1 & 4653.3 & 2.353 & 2384.5 & 2.484 & 5.3 & 6.2 & 6200.0 & 226 \\
\hline 22 & 9.5 & $\begin{array}{c}\text { Mille } \\
\text { d }\end{array}$ & None & 0 & 2330.8 & 1332.6 & 2335.2 & 2.325 & 6.3 & 0.0 & 4701.4 & 2702.9 & 4706.5 & 2.346 & 2370.6 & 2.482 & 5.5 & 4.8 & 6800.0 & 248 \\
\hline 23 & 9.5 & $\begin{array}{c}\text { Mille } \\
\text { d }\end{array}$ & SS-1h & 0.25 & 2247.1 & 1299.6 & 2250.1 & 2.364 & 4.7 & 9.2 & 4640.2 & 2675.4 & 4647.2 & 2.353 & 2383.9 & 2.487 & 5.4 & 6.1 & 4400.0 & 161 \\
\hline 24 & 9.5 & $\begin{array}{l}\text { Cut } \\
\text { Face }\end{array}$ & SS-1h & 0.25 & 2369.1 & 1348 & 2374.2 & 2.309 & 7.0 & 3.6 & 4759.6 & 2715.5 & 4766.1 & 2.321 & 2386.9 & 2.484 & 6.6 & 6.2 & 5200.0 & 190 \\
\hline 25 & 9.5 & $\begin{array}{c}\text { Mille } \\
\text { d }\end{array}$ & None & 0 & 2299.4 & 1332.3 & 2302.4 & 2.370 & 4.5 & 0.0 & 4685.4 & 2709.2 & 4689.6 & 2.366 & 2386.0 & 2.482 & 4.7 & 4.9 & 5700.0 & 208 \\
\hline 26 & 9.5 & $\begin{array}{l}\text { Cut } \\
\text { Face }\end{array}$ & SS-1h & 2 & 2394.2 & 1380.6 & 2397.1 & 2.355 & 5.1 & 3.6 & 4790.2 & 2757.0 & 4797.0 & 2.348 & 2392.4 & 2.484 & 5.5 & 5.9 & 5900.0 & 215 \\
\hline 27 & 9.5 & $\begin{array}{l}\text { Cut } \\
\text { Face }\end{array}$ & None & 0 & 2293.3 & 1312 & 2299.1 & 2.323 & 6.4 & 0.0 & 4679.5 & 2685.1 & 4687.1 & 2.337 & 2386.2 & 2.482 & 5.8 & 5.4 & 5000.0 & 182 \\
\hline 28 & 9.5 & $\begin{array}{c}\text { Mille } \\
\mathrm{d}\end{array}$ & SS-1h & 2 & 2465.4 & 1431.5 & 2467.5 & 2.380 & 4.1 & 9.2 & 4866.7 & 2817.6 & 4872.8 & 2.368 & 2392.1 & 2.487 & 4.8 & 5.7 & 5200.0 & 190 \\
\hline 29 & 9.5 & $\begin{array}{l}\text { Cut } \\
\text { Face }\end{array}$ & SS-1h & 0.25 & 2201.9 & 1273.8 & 2204.6 & 2.366 & 4.7 & 3.6 & 4593.2 & 2650.3 & 4599.3 & 2.357 & 2387.7 & 2.484 & 5.1 & 5.6 & 4800.0 & 175 \\
\hline 30 & 9.5 & $\begin{array}{c}\text { Mille } \\
\mathrm{d}\end{array}$ & $\begin{array}{l}\text { NTSS- } \\
1 \mathrm{HM} \\
\end{array}$ & 0.25 & 2218.9 & 1266 & 2222.6 & 2.320 & 6.5 & 9.2 & 4615.2 & 2649.1 & 4622.7 & 2.338 & 2387.1 & 2.487 & 6.0 & 5.5 & 5600.0 & 204 \\
\hline 31 & 9.5 & $\begin{array}{l}\text { Cut } \\
\text { Face }\end{array}$ & None & 0 & 2411.3 & 1396.8 & 2414.4 & 2.370 & 4.5 & 0.0 & 4810.6 & 2772.2 & 4820.6 & 2.348 & 2399.3 & 2.482 & 5.4 & 6.6 & 5400.0 & 197 \\
\hline 32 & 9.5 & $\begin{array}{c}\text { Mille } \\
\text { d }\end{array}$ & SS-1h & 0.25 & 2194.7 & 1255.3 & 2199.1 & 2.325 & 6.3 & 9.2 & 4599.8 & 2641.3 & 4607.0 & 2.340 & 2395.9 & 2.487 & 5.9 & 5.6 & 4400.0 & 161 \\
\hline
\end{tabular}




\begin{tabular}{|c|c|c|c|c|c|c|c|c|c|c|c|c|c|c|c|c|c|c|c|c|}
\hline$\frac{\frac{0}{\alpha}}{\frac{\varepsilon}{\tilde{D}}}$ & 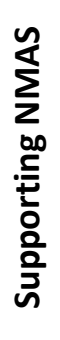 & 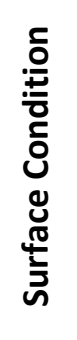 & 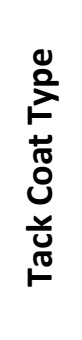 & 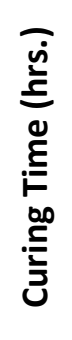 & 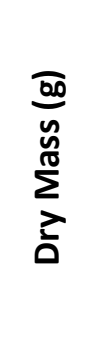 & 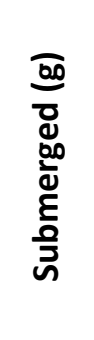 & 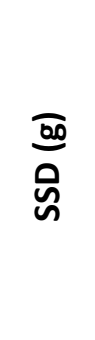 & 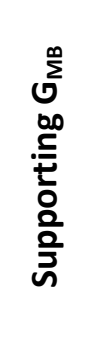 & 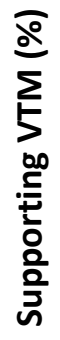 & 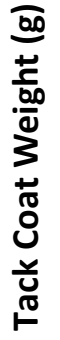 & 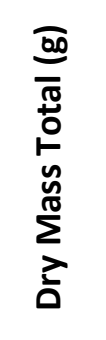 & 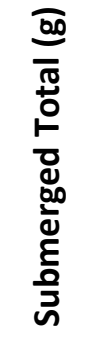 & 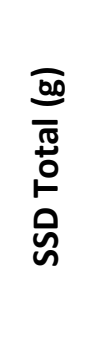 & $\frac{\sum_{0}^{\infty}}{\stackrel{\infty}{0}}$ & 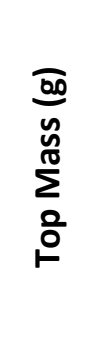 & 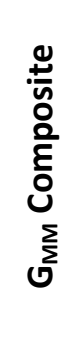 & 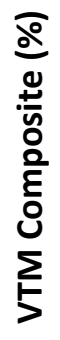 & $\begin{array}{l}\frac{\mathfrak{0}}{0} \\
\stackrel{0}{0} \\
\stackrel{5}{5} \\
5\end{array}$ & 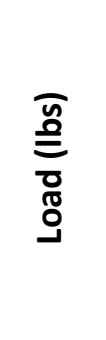 & 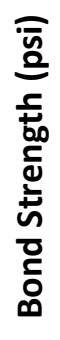 \\
\hline 33 & 9.5 & $\begin{array}{l}\text { Cut } \\
\text { Face }\end{array}$ & None & 0 & 2302.9 & 1330.4 & 2307.4 & 2.357 & 5.0 & 0.0 & 4692.0 & 2706.7 & 4702.3 & 2.351 & 2389.1 & 2.482 & 5.3 & 5.5 & 5600.0 & 204 \\
\hline 34 & 9.5 & $\begin{array}{l}\text { Cut } \\
\text { Face }\end{array}$ & $\begin{array}{l}\text { NTSS- } \\
1 \mathrm{HM}\end{array}$ & 0.25 & 2280.8 & 1324.8 & 2283.2 & 2.380 & 4.1 & 3.6 & 4668.5 & 2697.0 & 4676.9 & 2.358 & 2384.1 & 2.484 & 5.1 & 6.5 & 6100.0 & 223 \\
\hline 35 & 9.5 & $\begin{array}{l}\text { Cut } \\
\text { Face }\end{array}$ & $\begin{array}{l}\text { NTSS- } \\
1 \mathrm{HM}\end{array}$ & 0.25 & 2391.4 & 1381.2 & 2395.1 & 2.359 & 5.0 & 3.6 & 4791.6 & 2763.9 & 4802.4 & 2.351 & 2396.6 & 2.484 & 5.4 & 5.8 & 5900.0 & 215 \\
\hline 36 & 19 & $\begin{array}{l}\text { Cut } \\
\text { Face }\end{array}$ & None & 0 & 2545.4 & 1475.3 & 2556.1 & 2.355 & 6.2 & 0.0 & 4934.9 & 2840.3 & 4953.2 & 2.336 & 2389.5 & 2.497 & 6.5 & 6.7 & 5700.0 & 208 \\
\hline 37 & 9.5 & $\begin{array}{l}\text { Cut } \\
\text { Face }\end{array}$ & SS-1h & 2 & 2348.6 & 1360.9 & 2351.2 & 2.372 & 4.4 & 3.6 & 4743.1 & 2743.0 & 4750.1 & 2.363 & 2390.9 & 2.484 & 4.9 & 5.3 & 5800.0 & 212 \\
\hline 38 & 9.5 & $\begin{array}{c}\text { Mille } \\
\text { d }\end{array}$ & SS-1h & 2 & 2429.4 & 1388.2 & 2433.7 & 2.324 & 6.4 & 9.2 & 4826.6 & 2775.4 & 4833.9 & 2.345 & 2388.0 & 2.487 & 5.7 & 5.1 & 6000.0 & 219 \\
\hline 39 & 9.5 & $\begin{array}{l}\text { Cut } \\
\text { Face }\end{array}$ & None & 0 & 2230.4 & 1288.2 & 2233.7 & 2.359 & 5.0 & 0.0 & 4625.2 & 2664.4 & 4632.8 & 2.350 & 2394.8 & 2.482 & 5.3 & 5.7 & 6200.0 & 226 \\
\hline 40 & 9.5 & $\begin{array}{c}\text { Mille } \\
\text { d }\end{array}$ & $\begin{array}{l}\text { NTSS- } \\
1 \mathrm{HM}\end{array}$ & 0.25 & 2239.9 & 1298.8 & 2241.9 & 2.375 & 4.3 & 9.2 & 4638.9 & 2684.4 & 4647.9 & 2.363 & 2389.8 & 2.487 & 5.0 & 5.9 & 5400.0 & 197 \\
\hline 41 & 9.5 & $\begin{array}{c}\text { Mille } \\
\mathrm{d}\end{array}$ & SS-1h & 0.25 & 2221.1 & 1285.2 & 2224 & 2.366 & 4.7 & 9.2 & 4629.7 & 2676.4 & 4637.5 & 2.361 & 2399.4 & 2.487 & 5.1 & 5.5 & 4900.0 & 179 \\
\hline 42 & 9.5 & $\begin{array}{l}\text { Cut } \\
\text { Face }\end{array}$ & None & 0 & 2171 & 1255.1 & 2173.6 & 2.364 & 4.8 & 0.0 & 4571.7 & 2639.1 & 4582.1 & 2.353 & 2400.7 & 2.482 & 5.2 & 5.7 & 5900.0 & 215 \\
\hline 43 & 9.5 & $\begin{array}{c}\text { Mille } \\
\text { d }\end{array}$ & SS-1h & 2 & 2306.1 & 1336.3 & 2308.2 & 2.373 & 4.4 & 9.2 & 4703.0 & 2727.5 & 4701.5 & 2.382 & 2387.7 & 2.487 & 4.2 & 4.0 & 6200.0 & 226 \\
\hline 44 & 9.5 & $\begin{array}{l}\text { Cut } \\
\text { Face }\end{array}$ & SS-1h & 2 & 2284.6 & 1319.5 & 2286.6 & 2.362 & 4.8 & 3.6 & 4680.7 & 2701.6 & 4686.2 & 2.359 & 2392.5 & 2.484 & 5.0 & 5.3 & 6200.0 & 226 \\
\hline 45 & 9.5 & $\begin{array}{c}\text { Mille } \\
\text { d }\end{array}$ & SS-1h & 0.25 & 2197.5 & 1223.5 & 2200.3 & 2.250 & 9.4 & 9.2 & 4593.8 & 2641.4 & 4602.1 & 2.343 & 2387.1 & 2.487 & 5.8 & 4.3 & 3900.0 & 142 \\
\hline 46 & 9.5 & $\begin{array}{l}\text { Cut } \\
\text { Face }\end{array}$ & SS-1h & 0.25 & 2373.3 & 1368.7 & 2377.1 & 2.354 & 5.2 & 3.6 & 4765.5 & 2743.6 & 4774.3 & 2.347 & 2388.6 & 2.484 & 5.5 & 5.9 & 5000.0 & 182 \\
\hline 47 & 9.5 & $\begin{array}{c}\text { Mille } \\
\text { d }\end{array}$ & $\begin{array}{l}\text { NTSS- } \\
1 \mathrm{HM} \\
\end{array}$ & 0.25 & 2223.6 & 1289.4 & 2225.8 & 2.375 & 4.3 & 9.2 & 4619.1 & 2670.1 & 4627.1 & 2.360 & 2386.3 & 2.487 & 5.1 & 6.1 & 5100.0 & 186 \\
\hline 48 & 9.5 & $\begin{array}{l}\text { Cut } \\
\text { Face }\end{array}$ & SS-1h & 0.25 & 2309 & 1331.6 & 2312.7 & 2.353 & 5.2 & 3.6 & 4707.4 & 2719.5 & 4717.1 & 2.357 & 2394.8 & 2.484 & 5.1 & 5.1 & 5600.0 & 204 \\
\hline 49 & 9.5 & $\begin{array}{c}\text { Mille } \\
\text { d }\end{array}$ & SS-1h & 2 & 2296.3 & 1326.8 & 2298.6 & 2.363 & 4.8 & 9.2 & 4698.7 & 2710.6 & 4709.1 & 2.351 & 2393.2 & 2.487 & 5.5 & 6.3 & 6000.0 & 219 \\
\hline
\end{tabular}




\begin{tabular}{|c|c|c|c|c|c|c|c|c|c|c|c|c|c|c|c|c|c|c|c|c|}
\hline 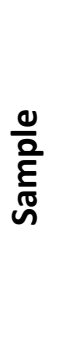 & 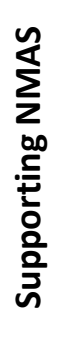 & 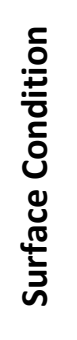 & 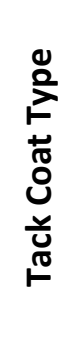 & 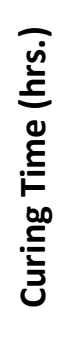 & 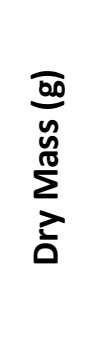 & 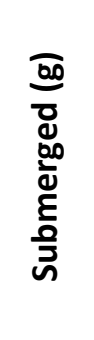 & 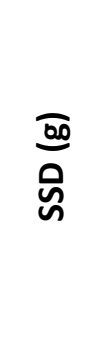 & 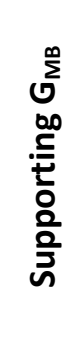 & 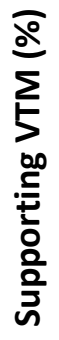 & 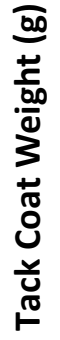 & 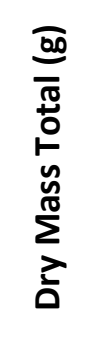 & 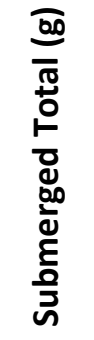 & 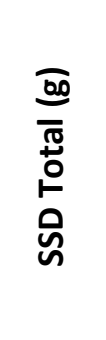 & $\frac{\sum_{0}^{\infty}}{\stackrel{\infty}{\pi}}$ & 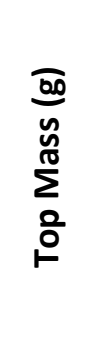 & 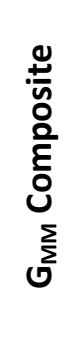 & 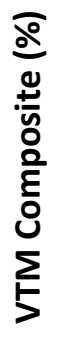 & $\begin{array}{l}\frac{\widehat{0}}{0} \\
\frac{0}{0} \\
\frac{1}{5} \\
5\end{array}$ & $\begin{array}{l}\bar{n} \\
\text { 兰 } \\
\overline{0} \\
0 \\
0\end{array}$ & 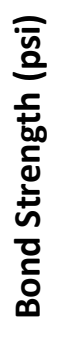 \\
\hline 50 & 19 & $\begin{array}{l}\text { Cut } \\
\text { Face }\end{array}$ & None & 0 & 2297.9 & 1330.1 & 2306.6 & 2.353 & 6.3 & 0.0 & 4635.1 & 2665.5 & 4651.7 & 2.334 & 2337.2 & 2.497 & 6.5 & 6.8 & 6300.0 & 230 \\
\hline 51 & 9.5 & $\begin{array}{l}\text { Cut } \\
\text { Face }\end{array}$ & SS-1h & 2 & 2348.2 & 1356.9 & 2351.1 & 2.362 & 4.8 & 3.6 & 4744.0 & 2742.1 & 4752.1 & 2.360 & 2392.2 & 2.484 & 5.0 & 5.1 & 6100.0 & 223 \\
\hline 52 & 9.5 & $\begin{array}{l}\text { Cut } \\
\text { Face }\end{array}$ & SS-1h & 0.25 & 2476 & 1432.5 & 2480.4 & 2.363 & 4.8 & 3.6 & 4868.5 & 2820.7 & 4878.3 & 2.366 & 2388.9 & 2.484 & 4.7 & 4.7 & 5800.0 & 212 \\
\hline 53 & 19 & $\begin{array}{l}\text { Cut } \\
\text { Face }\end{array}$ & None & 0 & 2494.2 & 1451 & 2503 & 2.371 & 5.6 & 0.0 & 4898.3 & 2833.4 & 4910.9 & 2.358 & 2404.1 & 2.497 & 5.6 & 5.5 & 7100.0 & 259 \\
\hline 54 & 9.5 & $\begin{array}{l}\text { Cut } \\
\text { Face }\end{array}$ & $\begin{array}{l}\text { NTSS- } \\
1 \mathrm{HM}\end{array}$ & 0.25 & 2346.4 & 1358.3 & 2350 & 2.366 & 4.7 & 3.6 & 4749.7 & 2742.8 & 4758.0 & 2.357 & 2399.7 & 2.484 & 5.1 & 5.6 & 7700.0 & 281 \\
\hline
\end{tabular}

\begin{tabular}{|c|c|c|c|c|c|c|c|c|c|c|c|c|c|c|c|c|c|c|c|c|}
\hline \multicolumn{3}{|c|}{ 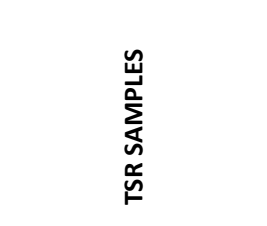 } & \multirow{2}{*}{ 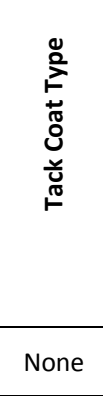 } & \multirow{2}{*}{ 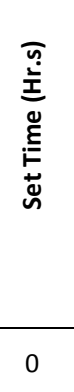 } & \multirow{2}{*}{ 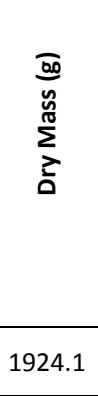 } & \multirow{2}{*}{ 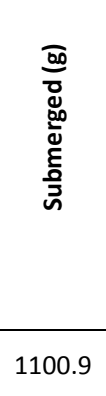 } & \multirow{2}{*}{$\begin{array}{c}\overline{\text { ज0 }} \\
\text { 气ิ } \\
1931.9\end{array}$} & \multirow{2}{*}{ 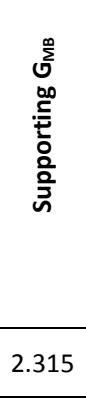 } & \multirow{2}{*}{ 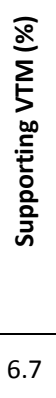 } & \multirow{2}{*}{ 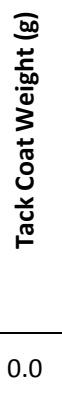 } & \multirow{2}{*}{ 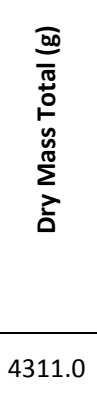 } & \multirow{2}{*}{ 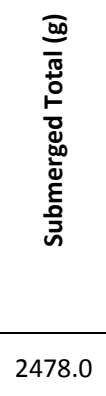 } & \multirow{2}{*}{ 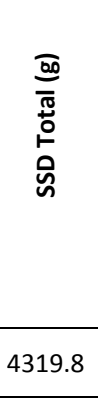 } & \multirow{2}{*}{ 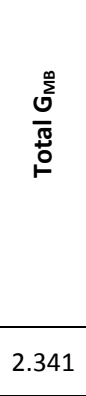 } & \multirow{2}{*}{ 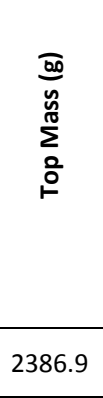 } & \multirow{2}{*}{ 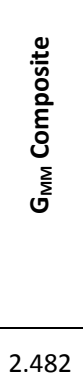 } & \multirow{2}{*}{ 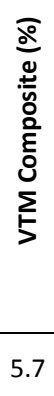 } & \multirow{2}{*}{$\begin{array}{l}\frac{\bar{\Xi}}{0} \\
\stackrel{0}{\circ} \\
\sum \\
5\end{array}$} & \multirow{2}{*}{ 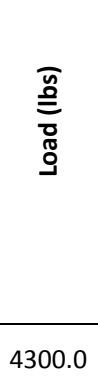 } & \multirow{2}{*}{ 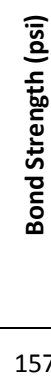 } \\
\hline 55 & 9.5 & $\begin{array}{l}\text { Cut } \\
\text { Face }\end{array}$ & & & & & & & & & & & & & & & & & & \\
\hline 56 & 9.5 & $\begin{array}{l}\text { Mille } \\
\text { d }\end{array}$ & SS-1h & 0.25 & 2404.8 & 1412.9 & 2406.6 & 2.420 & 2.5 & 9.2 & 4812.6 & 2797.4 & 4819.6 & 2.380 & 2398.6 & 2.487 & 4.3 & 15.3 & 4000.0 & 146 \\
\hline 57 & 9.5 & $\begin{array}{l}\text { Cut } \\
\text { Face }\end{array}$ & $\begin{array}{c}\text { NTTSS- } \\
1 \mathrm{HM}\end{array}$ & 0.25 & 2064.6 & 1207.6 & 2066.1 & 2.405 & 3.1 & 3.6 & 4466.1 & 2588.9 & 4474.4 & 2.369 & 2397.9 & 2.484 & 4.6 & 8.1 & 4100.0 & 150 \\
\hline 58 & 9.5 & $\begin{array}{l}\text { Mille } \\
\text { d }\end{array}$ & None & 0 & 2278.6 & 1320.2 & 2281.7 & 2.370 & 4.5 & 0.0 & 4674.1 & 2693.4 & 4685.8 & 2.346 & 2395.5 & 2.482 & 5.5 & 6.9 & 4500.0 & 164 \\
\hline 59 & 9.5 & $\begin{array}{l}\text { Cut } \\
\text { Face }\end{array}$ & SS-1h & 0.25 & 2124.8 & 1238.7 & 2126.4 & 2.394 & 3.6 & 3.6 & 4507.6 & 2595.5 & 4519.0 & 2.343 & 2379.2 & 2.484 & 5.7 & 11.9 & 3300.0 & 120 \\
\hline 60 & 9.5 & $\begin{array}{c}\text { Mille } \\
\text { d }\end{array}$ & $\begin{array}{c}\text { NTTSS- } \\
1 \mathrm{HM}\end{array}$ & 0.25 & 2246.9 & 1282.5 & 2254 & 2.313 & 6.8 & 9.2 & 4581.6 & 2634.6 & 4597.0 & 2.335 & 2325.5 & 2.487 & 6.1 & 5.6 & 4500.0 & 164 \\
\hline
\end{tabular}




\begin{tabular}{|c|c|c|c|c|c|c|c|c|c|c|c|c|c|c|c|c|c|c|c|c|}
\hline $\begin{array}{l}\frac{0}{\frac{0}{\alpha}} \\
\frac{\varepsilon}{\mathbb{D}} \\
\text { ผ }\end{array}$ & 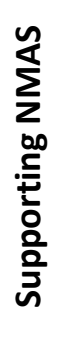 & 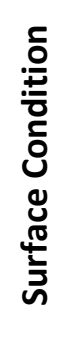 & 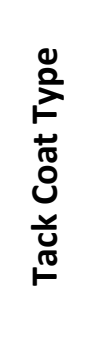 & 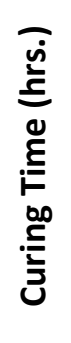 & 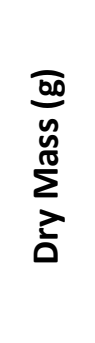 & 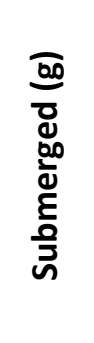 & 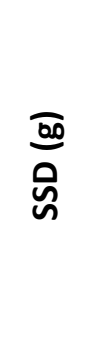 & 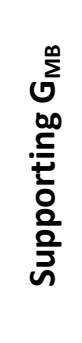 & 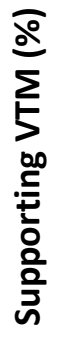 & 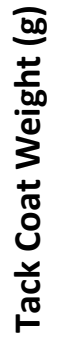 & 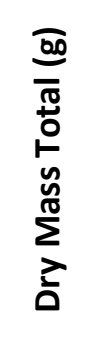 & 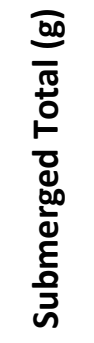 & 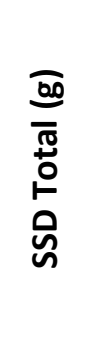 & $\frac{\sum_{0}^{\infty}}{\stackrel{\infty}{\mathbb{D}}}$ & 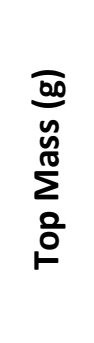 & 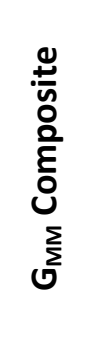 & 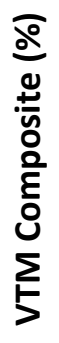 & $\begin{array}{l}\frac{\widehat{0}}{0} \\
\frac{0}{0} \\
\frac{1}{5} \\
5\end{array}$ & 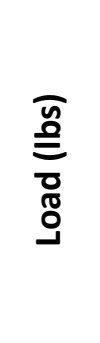 & 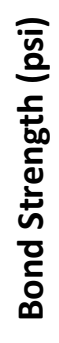 \\
\hline 61 & 9.5 & $\begin{array}{l}\text { Cut } \\
\text { Face }\end{array}$ & None & 0 & 2116.6 & 1200.7 & 2126.1 & 2.287 & 7.8 & 0.0 & 4491.9 & 2569.4 & 4513.3 & 2.311 & 2375.3 & 2.482 & 6.9 & 6.2 & 4500.0 & 164 \\
\hline 62 & 9.5 & $\begin{array}{c}\text { Mille } \\
\text { d }\end{array}$ & SS-1h & 0.25 & 2323.6 & 1338.4 & 2331 & 2.341 & 5.7 & 9.2 & 4709.7 & 2709.6 & 4726.1 & 2.336 & 2376.9 & 2.487 & 6.1 & 6.5 & 4300.0 & 157 \\
\hline 63 & 9.5 & $\begin{array}{l}\text { Cut } \\
\text { Face }\end{array}$ & $\begin{array}{c}\text { NTTSS- } \\
1 \mathrm{HM}\end{array}$ & 0.25 & 2217.5 & 1258.3 & 2226.6 & 2.290 & 7.7 & 3.6 & 4617.1 & 2647.9 & 4633.4 & 2.325 & 2396.0 & 2.484 & 6.4 & 5.5 & 4300.0 & 157 \\
\hline 64 & 9.5 & $\begin{array}{c}\text { Mille } \\
\text { d }\end{array}$ & None & 0 & 2127.9 & 1216.9 & 2133.2 & 2.322 & 6.4 & 0.0 & 4534.2 & 2607.7 & 4545.1 & 2.340 & 2406.3 & 2.482 & 5.7 & 5.2 & 4600.0 & 168 \\
\hline 65 & 9.5 & $\begin{array}{l}\text { Cut } \\
\text { Face }\end{array}$ & SS-1h & 0.25 & 2174.8 & 1232.9 & 2184.5 & 2.285 & 7.9 & 3.6 & 4582.9 & 2622.9 & 4597.7 & 2.321 & 2404.5 & 2.484 & 6.6 & 5.7 & 3500.0 & 128 \\
\hline 66 & 9.5 & $\begin{array}{c}\text { Mille } \\
\text { d }\end{array}$ & $\begin{array}{c}\text { NTTSS- } \\
1 \mathrm{HM}\end{array}$ & 0.25 & 2176.7 & 1245.8 & 2184 & 2.320 & 6.5 & 9.2 & 4581.1 & 2639.6 & 4596.7 & 2.341 & 2395.2 & 2.487 & 5.9 & 5.4 & 5100.0 & 186 \\
\hline
\end{tabular}


APPENDIX 7: SAMPLE CONDITIONING DATA

\begin{tabular}{|c|c|c|c|c|c|c|c|c|c|c|c|c|c|}
\hline \multicolumn{2}{|l|}{ Sample \# } & 55 & 56 & 57 & 58 & 59 & 60 & 61 & 62 & 63 & 64 & 65 & 66 \\
\hline Dry Mass in air, $\mathrm{g}$ & $A$ & 4311 & 4812.6 & 4466.1 & 4674.1 & 4507.6 & 4581.6 & 4491.9 & 4709.7 & 4617.1 & 4534.2 & 4582.9 & 4581.1 \\
\hline SSD Mass, g & B & 4319.8 & 4819.6 & 4474.4 & 4685.8 & 4519 & 4597 & 4513.3 & 4726.1 & 4633.4 & 4545.1 & 4597.7 & 4596.7 \\
\hline Mass in Water, $\mathrm{g}$ & $\mathrm{C}$ & 2478 & 2797.4 & 2588.9 & 2693.4 & 2595.5 & 2634.6 & 2569.4 & 2709.6 & 2647.9 & 2607.7 & 2622.9 & 2639.6 \\
\hline Volume $(B-C), \mathrm{cm}^{3}$ & $\mathrm{E}$ & 1841.8 & 2022.2 & 1885.5 & 1992.4 & 1923.5 & 1962.4 & 1943.9 & 2016.5 & 1985.5 & 1937.4 & 1974.8 & 1957.1 \\
\hline $\begin{array}{l}\text { Bulk Specific Gravity, } \\
\text { A/E }\end{array}$ & $\begin{array}{c}\mathrm{G} \\
\mathrm{mb}\end{array}$ & 2.341 & 2.380 & 2.369 & 2.346 & 2.343 & 2.335 & 2.311 & 2.336 & 2.325 & 2.340 & 2.321 & 2.341 \\
\hline $\begin{array}{l}\text { Maximum Specific } \\
\text { Gravity }\end{array}$ & $\begin{array}{c}\mathrm{G} \\
\mathrm{m} \\
\mathrm{m}\end{array}$ & 2.482 & 2.482 & 2.482 & 2.482 & 2.482 & 2.482 & 2.482 & 2.482 & 2.482 & 2.482 & 2.482 & 2.482 \\
\hline$\%$ Air Voids & $\mathrm{P}_{\mathrm{a}}$ & 5.7 & 4.3 & 4.6 & 5.5 & 5.7 & 6.1 & 6.9 & 6.1 & 6.4 & 5.7 & 6.6 & 5.9 \\
\hline $\begin{array}{l}\text { Volume of Air Voids, } \\
P_{a} E / 100, \mathrm{~cm}^{3}\end{array}$ & $\mathrm{~V}_{\mathrm{a}}$ & 105 & 87 & 88 & 109 & 109 & 120 & 134 & 123 & 127 & 111 & 130 & 115 \\
\hline \multicolumn{2}{|c|}{$\begin{array}{l}\text { Saturated time (min) and } \\
\text { inches of mercury }\end{array}$} & $\begin{array}{l}4 @ 20 \\
\text { inches }\end{array}$ & $\begin{array}{l}6 @ 20 \\
\text { inches }\end{array}$ & $\begin{array}{l}6 @ 20 \\
\text { inches }\end{array}$ & $\begin{array}{l}4 @ 20 \\
\text { inches }\end{array}$ & $\begin{array}{l}4 \text { @ } 20 \\
\text { inches }\end{array}$ & $\begin{array}{c}3: 50 @ \\
20 \text { inches }\end{array}$ & $\begin{array}{l}\text { 3:20 @ } 20 \\
\text { inches }\end{array}$ & $\begin{array}{c}3: 40 @ \\
20 \text { inches }\end{array}$ & $\begin{array}{l}3 @ 20 \\
\text { inches }\end{array}$ & $\begin{array}{c}3: 30 @ \\
20 \text { inches }\end{array}$ & $\begin{array}{c}2: 40 @ \\
20 \text { inches }\end{array}$ & $\begin{array}{c}3: 40 @ \\
20 \text { inches }\end{array}$ \\
\hline Thickness (mm) & $\mathrm{t}^{\prime}$ & 106.7 & 116 & 108.5 & 115 & 110.3 & 113.1 & 112.5 & 116.5 & 0 & 0 & 0 & 0 \\
\hline SSD Mass, g & $B^{\prime}$ & 4389.1 & 4874.7 & 4529.8 & 4751.2 & 4590.4 & 4672 & 4595.2 & 4803.3 & 4715.6 & 4618.3 & 4686 & 4669.8 \\
\hline $\begin{array}{l}\text { Volume of Absorbed } \\
\text { water }\left(B^{\prime}-A\right), \mathrm{cm}^{3}\end{array}$ & $\mathrm{~J}^{\prime}$ & 78.1 & 62.1 & 63.7 & 77.1 & 82.8 & 90.4 & 103.3 & 93.6 & 98.5 & 84.1 & 103.1 & 88.7 \\
\hline $\begin{array}{l}\text { \% Saturation } \\
(100 \mathrm{~J} / \mathrm{Va})\end{array}$ & $S^{\prime}$ & 74 & 71 & 73 & 71 & 76 & 75 & 77 & 76 & 78 & 76 & 79 & 77 \\
\hline
\end{tabular}




\section{APPENDIX 7: STATISTICAL ANALYSIS}

\begin{tabular}{|c|c|c|c|c|c|c|c|c|c|c|c|c|c|c|c|c|}
\hline & & & 1 & 2 & 3 & 4 & 5 & 6 & 7 & 8 & 9 & 10 & 11 & 12 & 13 & 14 \\
\hline 1 & 9.5, Milled, SS-1h, $.25 \mathrm{hrs}$. & 1 & & & & & & & & & & & & & & \\
\hline 2 & 9.5, Milled, SsS-1h, 2 hrs. & 2 & 0.032 & & & & & & & & & & & & & \\
\hline 3 & 9.5, Milled No Tack & 3 & 0.001 & 0.376 & & & & & & & & & & & & \\
\hline 4 & 9.5, Milled, NTTSS-1HM, .25 hrs. & 4 & 0.001 & 0.923 & 0.155 & & & & & & & & & & & \\
\hline 5 & 9.5, Cut Face SS-1h, $.25 \mathrm{hrs}$. & 5 & 0.018 & 0.567 & 0.077 & 0.406 & & & & & & & & & & \\
\hline 6 & 9.5, Cut Face, SS-1h, 2 hrs. & 6 & 0.000 & 0.301 & 0.953 & 0.070 & 0.028 & & & & & & & & & \\
\hline 7 & 9.5, Cut Face, No Tack & 7 & 0.003 & 0.797 & 0.414 & 0.583 & 0.274 & 0.292 & & & & & & & & \\
\hline 8 & 9.5, Cut Face NTTSS-1HM, .25 hrs. & 8 & 0.003 & 0.195 & 0.49 & 0.097 & 0.055 & 0.474 & 0.203 & & & & & & & \\
\hline 9 & 19, Cut Face, No Tack & 9 & 0.011 & 0.442 & 0.942 & 0.305 & 0.177 & 0.969 & 0.508 & 0.609 & & & & & & \\
\hline 10 & 9.5, Milled No Tack Conditioned & 10 & 0.696 & 0.137 & 0.019 & 0.004 & 0.056 & 0.002 & 0.0275 & 0.049 & 0.094 & & & & & \\
\hline 11 & $\begin{array}{l}\text { 9.5, Cut Face NTTSS-1HM, } .25 \text { hrs. } \\
\text { Conditioned }\end{array}$ & 11 & 0.308 & 0.085 & 0.011 & 0.001 & 0.025 & 0.001 & 0.0141 & 0.033 & 0.063 & 0.293 & & & & \\
\hline 12 & 9.5, Cut Face SS-1h, .25 hrs. Conditioned & 12 & 0.008 & 0.014 & 0.002 & $8 \mathrm{E}-05$ & 0.0017 & $1 E-04$ & 0.0015 & 0.008 & 0.014 & 0.019 & 0.030 & & & \\
\hline 13 & 9.5, Milled No Tack Conditioned & 13 & 0.910 & 0.194 & 0.03 & 0.007 & 0.1024 & 0.004 & 0.0456 & 0.066 & 0.126 & 0.312 & 0.089 & 0.009 & & \\
\hline 14 & $\begin{array}{l}\text { 9.5, Milled, NTTSS-1HM, . } 25 \text { hrs. } \\
\text { Conditioned }\end{array}$ & 14 & 0.402 & 0.355 & 0.076 & 0.062 & 0.3245 & 0.019 & 0.1329 & 0.116 & 0.212 & 0.333 & 0.198 & 0.047 & 0.497 & \\
\hline 15 & 9.5, Milled, SS-1h, .25 hrs. Conditioned & 15 & 0.252 & 0.077 & 0.01 & 0.001 & 0.0217 & 0.001 & 0.0125 & 0.031 & 0.058 & 0.300 & 0.808 & 0.053 & 0.127 & 0.192 \\
\hline
\end{tabular}

